UNIVERSIDADE DE SÃo PAULO
Programa de Pós-GRAdUAÇÃo INTERUNIDADES EM ENSINO DE CIÊNCIAS

FABIANA RodRIGUES SANTOS

Detetive ou cientista? A literatura policial infanto-juvenil como recurso didático na educação em ciências

São Paulo

2013 


\section{FABIANA RODRIGUES SANTOS}

Detetive ou cientista? A literatura policial infanto-juvenil como recurso didático na educação em ciências

Dissertação apresentada ao Instituto de Física da Universidade de São Paulo para obtenção do título de Mestre em Ensino de Ciências

Área de Concentração: Ensino de Física

Orientador: Prof. Dr. Luís Paulo de Carvalho Piassi

São Paulo 2013 
Autorizo a reprodução e divulgação total ou parcial deste trabalho, por qualquer meio convencional ou eletrônico, para fins de estudo e pesquisa, desde que citada a fonte.

\section{FICHA CATALOGRÁFICA \\ Preparada pelo Serviço de Biblioteca e Informação do Instituto de Física da Universidade de São Paulo}

Santos, Fabiana Rodrigues

Detetive ou cientista? A literatura policial infanto-juvenil como recurso didático na educação em ciências. - São Paulo, 2013.

Dissertação (Mestrado) - Universidade de São Paulo. Faculdade de Educação, Instituto de Física, Instituto de Química e Instituto de Biociências.

Orientador: Prof. Dr. Luís Paulo de Carvalho Piassi

Área de Concentração: Ensino de física

Unitermos: 1. Ciências (Estudo e ensino); 2. Literatura infanto-juvenil; 3. Romance policial; 4. Propostas didáticas; 5 . Investigação científica.

USP/IF/SBI-096/2013 
Ao meu esposo Diogo por ser meu alicerce e por fazer parte da minha vida. 


\section{AGRADECIMENTOS}

Agradeço inicialmente a Deus por me dar força para suportar os desafios cotidianos e por sempre me acolher com amor em seus braços protetores tornando este trabalho possível.

Aos meus pais Cleuza e Dilson, ao meu irmão Fabio e a minha sogra Marli pelo acompanhamento, apoio e pela compreensão sempre demonstrada. Também pelas conversas, e pelos estímulos dedicados.

Ao meu esposo Diogo, por todo seu carinho, auxílio, dedicação e por compreender a importância dessa conquista para nossas vidas.

Ao meu orientador Prof. Dr. Luís Paulo Piassi por sua paciência, seus ensinamentos confiança e encorajamentos ao me mostrar na Academia um caminho para a vida.

Ao Programa de Pós-graduação Interunidades representado pela Comissão de Pós, os professores e funcionários.

À Prof ${ }^{\mathrm{a}} \mathrm{Dr}^{\mathrm{a}}$ Maria Regina D. Kawamura e ao Prof. Dr. Thomas Haddad pelas diversas contribuições durante a qualificação que possibilitaram a consolidação e o aprimoramento da pesquisa.

Ao grupo INTERFACES-NERD, Rosana, Emerson Santos, Emerson Gomes, Ricardo, Francisco, Rui, Paula, e tantos outros que muito acrescentaram nas discussões, reflexões e momentos de descontração. Quero agradecer em especial ao João pelo auxílio e tempo desprendido nos estudos das matérias em que tive dificuldades.

À minha amiga Estefânia por me ajudar com toda sua delicadeza e carinho nos momentos de dúvidas e dificuldades, me oferecendo sua presença, conhecimento e incentivo.

À Kátia e ao Hugo pelas conversas que muito contribuíram para a consolidação de ideias.

Aos meus amigos Luciana, Fran, Kátia, Anderson, Érika, Simone, Julio e Edson pela amizade sincera e por me proporcionaram momentos de distração nas ocasiões que mais precisei.

Agradeço a todas as pessoas do meu convívio que acreditaram e contribuíram, mesmo que indiretamente, para a conclusão deste trabalho.

À CAPES pelo apoio financeiro. 
"O romance policial é o modelo muito aperfeiçoado da investigação científica." Boileau - Narcejac

"Ensinar não é transferir conhecimento, mas criar as possibilidades para a sua própria produção ou a sua construção." Paulo Freire 
SANTOS, F. R. Detetive ou cientista? A literatura policial infanto-juvenil como recurso didático na educação em ciências. Dissertação (Mestrado). Instituto de Física, Instituto de Química, Instituto de Biociências, faculdade de Educação da Universidade de São Paulo. São Paulo: Universidade de São Paulo, 2013.

\section{RESUMO}

Nessa pesquisa apresentamos uma proposta didática pautada no uso da literatura no ensino de ciências a partir do uso de um gênero literário específico, o romance policial juvenil, no ensino da Investigação Científica. A obra utilizada como modelo é $O$ caso da borboleta Atíria de Lúcia Machado de Almeida, que possui um enredo pautado em mistério e investigação policial e faz parte da Série Vaga Lume da editora Ática. As obras literárias que compõe a Série estão presentes nas salas de aula e bibliotecas escolares, desde a década de setenta e fazem parte do repertório de leitura de muitos alunos atualmente. Além disso, elas estão repletas de conteúdos que permeiam várias áreas do conhecimento. Um dos procedimentos utilizados de análise da obra foi o uso da semiótica de Greimas (1976) que procura estabelecer as relações sintáxicas no interior de um texto, podendo auxiliar em um trabalho de interpretação mais profunda. Também realizamos a análise do discurso tendo como aporte teórico Maingueneau (2006), que estabelece parâmetros que nos permitem avaliar as principais características e as condições de êxito para os gêneros do discurso, estudando o processo de produção da obra, tendo como base o contexto sociocultural, evidenciando elementos a serem considerados no processo de ensino-aprendizagem relacionados à estrutura da obra e ao contexto sociocultural em que ela está inserida. Com essas análises, notamos que a obra tem como foco a busca do conhecimento por meio da investigação, possibilitando a elaboração de propostas didáticas para o ensino da Investigação Científica. Sendo assim, elaboramos propostas didáticas com o uso da obra para a abordagem da investigação científica no ensino de ciências voltadas para nível do Ensino Fundamental II. Essas propostas foram aplicadas em uma escola da cidade de São Paulo com o objetivo de reformular e aprimorar as propostas, possibilitando seu uso em diversos contextos escolares de forma interdisciplinar.

Palavras-chave: Literatura infanto-juvenil, romance policial, investigação científica, análise semiótica e do discurso, propostas didáticas. 
SANTOS, F. R. Detective or scientist? The juvenile crime fiction as a teaching resource in science education. Dissertação (Mestrado). Instituto de Física, Instituto de Química, Instituto de Biociências, faculdade de Educação da Universidade de São Paulo. São Paulo: Universidade de São Paulo, 2013.

\section{ABSTRACT}

In this research we propose a guided didactic use of literature in science education from the use of a specific literary genre, the crime novel, in Scientific Research's teaching. The book $O$ caso da borboleta Atíria was used as a model, written by Lucia Machado de Almeida, in which story is based in mystery and police investigation and is part of the publisher Ática, in Vaga Lume collection. The Literary that make up this collection are present in classrooms and school libraries since the seventies and are part of the repertoire of many students currently reading. Moreover, they are filled with content that permeate many areas of knowledge. One of the procedures used for analysis of the work was the use of semiotics of Greimas (1976) who seeks to establish syntactic relations within a text, and may help in a deeper interpretation work. We also conducted the analysis of discourse based in Maingueneau's theory (2006), which sets parameters that allow us to assess the main characteristics and the conditions of success for speech genres, studying the production process of the work, based on the social and culture contexts, showing elements to be considered in the process of teaching and learning related to the structure of the work and to the context in which it is embedded. With those analyses, we note that the work has a focus on to the search for knowledge through research, allowing the preparation of didactic proposals for the Scientific Research teaching. Thus, we elaborate didactic proposals using the book to approach scientific research in science teaching aimed at the elementary school. These proposals have been implemented in a school in the city of São Paulo in order to reshape and refine the proposals, enabling its use in different school contexts in an interdisciplinary way.

Keywords: Literature juvenile, detective novel, scientific research, semiotic analysis and discourse, didactic proposals. 


\section{SUMÁRIO}

\section{CAPÍTULO 1: LITERATURA INFANTO-JUVENIL E ENSINO DE CIÊNCIAS............1}

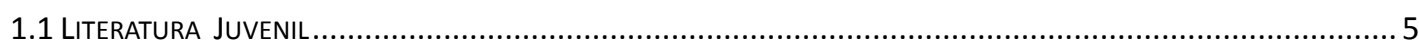

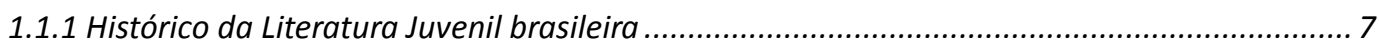

1.1.2 Literatura Contemporânea Brasileira ………………........................................................ 9

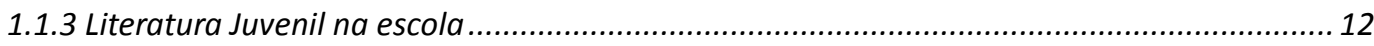

CAPÍTULO 2: ROMANCE POLICIAL E INVESTIGAÇÃO ....................................... 15

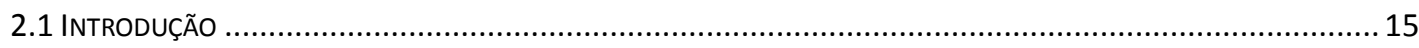

2.1.1 Dupin de Edgar Allan Poe: a invenção do romance de enigma ............................................ 16

2.1.2. Sherlock Holmes de Conan Doyle ....................................................................... 18

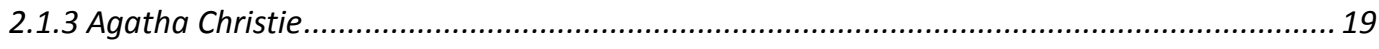

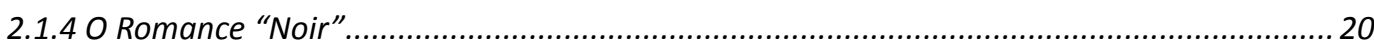

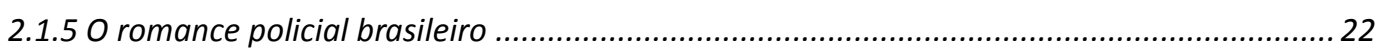

CAPÍTULO 3: O CASO DA BORBOLETA ATÍRIA ..............................................................2 27

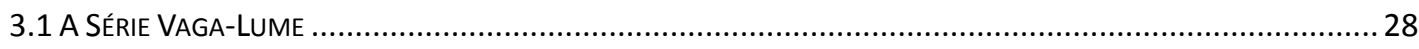

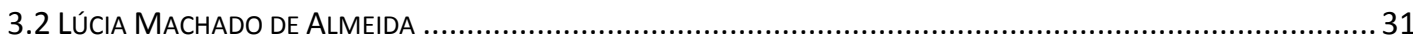

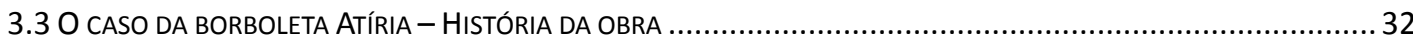

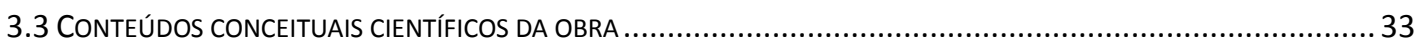

3.4 ESTABELECENDO RELAÇÕES ENTRE A PESQUISA CIENTífICA E A INVESTIGAÇão DO DETETIVE ...............................36

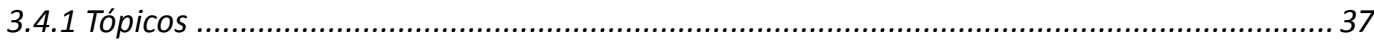

3.4.2 Interfaces entre a história e a pesquisa científica ....................................................... 39

CAPÍTULO 4: ANÁLISES ............................................................................................................... 43

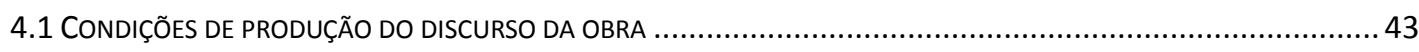

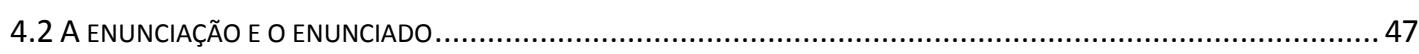

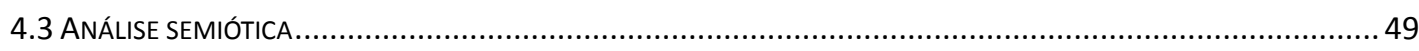

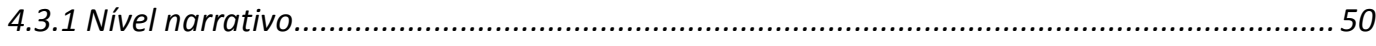

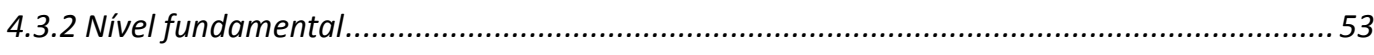

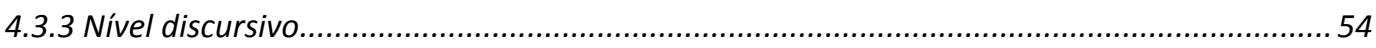

CAPÍTULO 5: POSSIBILIDADES E PROPOSTAS..............................................................57

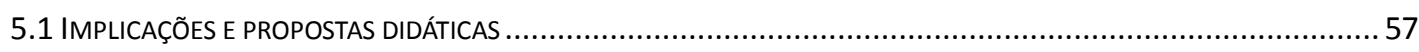

5.1.1 Bloco 1: Avaliação diagnóstica e sensibilização para o tema ...............................................60 
5.1.3 Bloco 3: Teorias epistemológicas da construção da ciência .............................................. 75

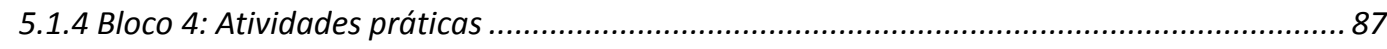

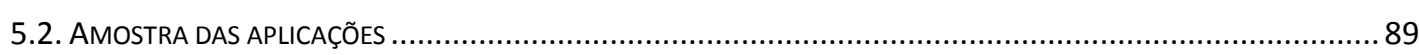

CONSIDERAÇÕES FINAIS....................................................................................................96

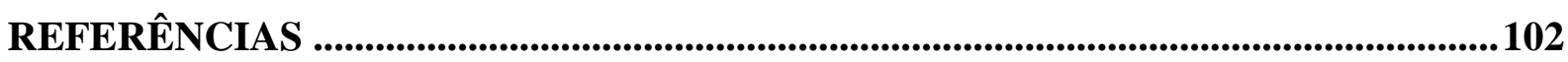

ANEXO A - FICHA DE LEITURA DO LIVRO O CASO DA BORBOLETA ATÍRA.107

ANEXO B - OBRAS QUE FAZEM PARTE DA SÉRIE VAGA-LUME ..........................109

ANEXO C - CAPAS DAS EDIÇÕES DE O CASO DA BORBOLETA ATÍRIA ............112

ANEXO D - CONTRACAPA DO LIVRO O CASO DA BORBOLETA ATÍRIA COM A

CAPA DE OUTROS EXEMPLARES ...................................................................................... 112 


\section{ÍNDICE DE FIGURAS}

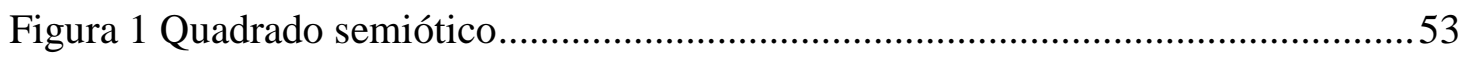

Figura 2 Quadro semiótico saber/ versus/ ignorância................................................54

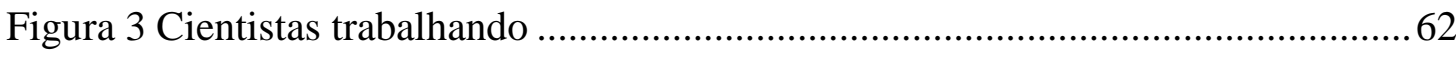

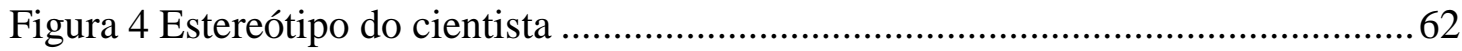

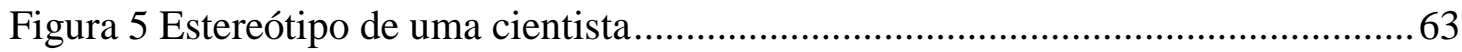

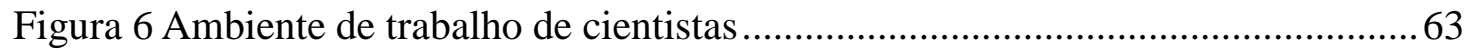

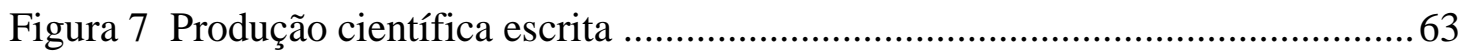

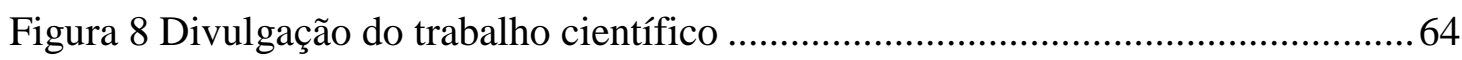

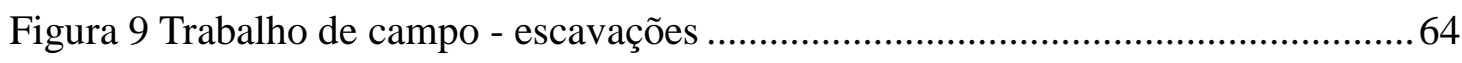

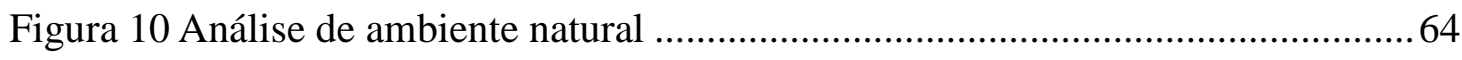

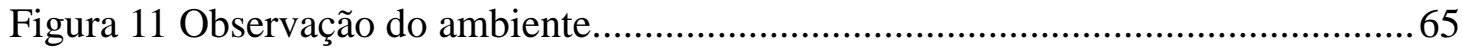

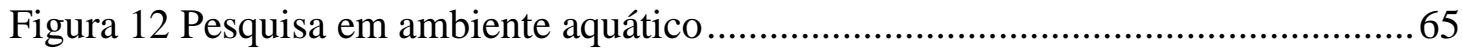

Figura 13 Organização de materiais coletados em campo...........................................65

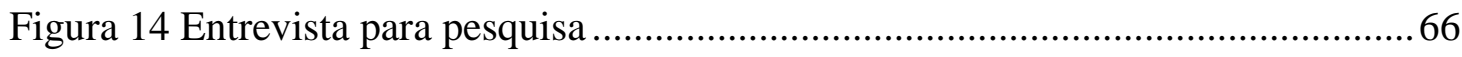

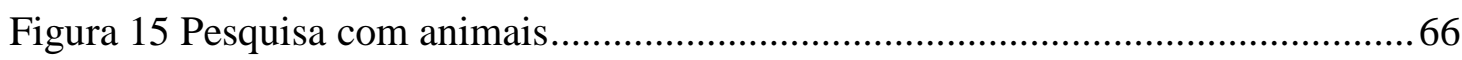

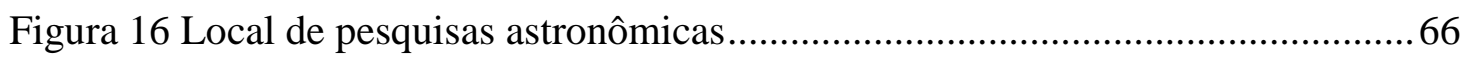

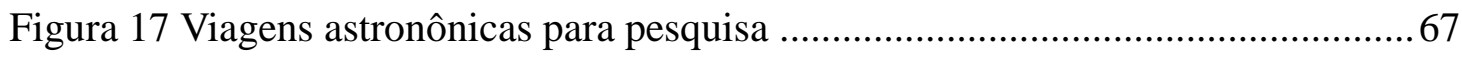

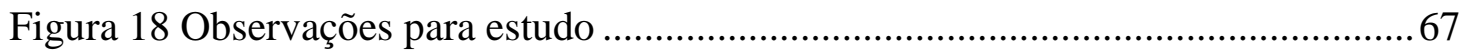

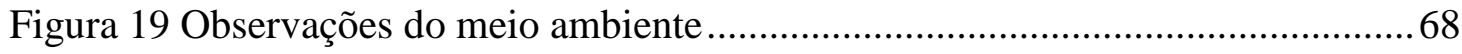

Figura 20 Realização e acompanhamento de pesquisa..................................................6 68

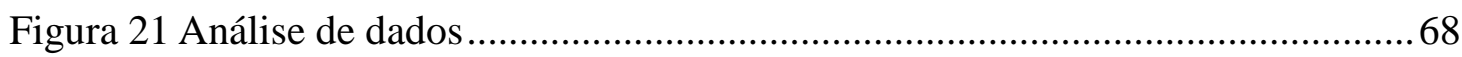

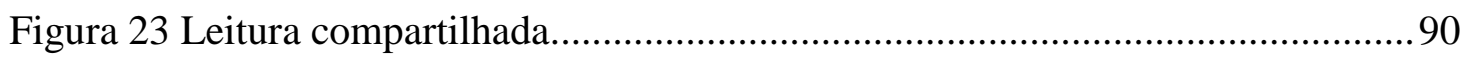

Figura 25 - Relato de um aluno sobre hipóteses e fatos da história ............................91

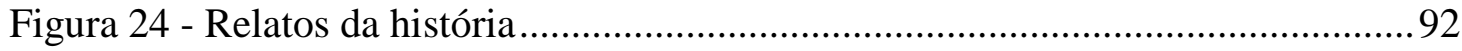

Figura 25 - Atividade sobre a história........................................................................... 92

Figura 26 Relacionando o detetive com o cientista ....................................................93

Figura 27 Relacionando a história com a pesquisa científica.....................................94

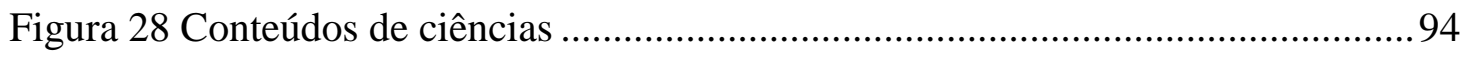

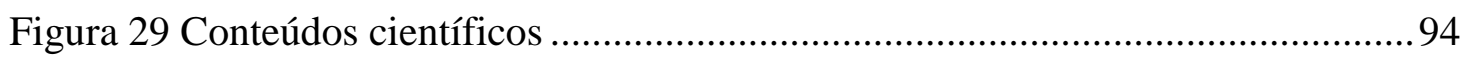

Figura 30 Capas de edições diversas da obra O caso da borboleta Atíria .................. 112

Figura 31 Contracapa da obra O caso da borboleta Atíria ......................................... 112 


\section{Apresentação}

Sempre gostei de ciências e de ler. Adorava quando chegavam os livros novos da escola e folheava-os, especialmente os de ciências. Olhava as gravuras, lia os novos conteúdos, relia os livros dos anos anteriores. Vivi os anos 90, uma época de grandes transformações, as pessoas passaram a ter um computador pessoal, acesso a internet. Eu não tive tão logo, pois minha família sempre foi muito simples, mas acompanhava os avanços pela escola, por colegas que já possuíam o tão desejado personal computer. Quando meus pais adquiriram o computador na metade da década de 1990, foi uma mudança sensível em minha vida.

E o tempo foi passando, fui me apegando cada vez mais em ciências. Os trabalhos de escola feitos com a ajuda da internet ficavam cada vez mais ricos e ilustrados. A quantidade de informação já parecia ser infinita, nada indicava que a internet seria, um dia, tão repleta de lixo virtual como é agora. Não havia redes sociais, conversávamos pessoalmente, por carta em punho ou e-mail. Mas ainda era pessoal. Enquanto isso fui crescendo e minhas habilidades com a ciência foram aflorando. Era boa em física, em química e em biologia durante o antigo colegial. Mas a questão persistia: Que faculdade eu faria? Via minhas professoras da escola e me sentia instigada a seguir o caminho da docência, mas não queria me especializar somente em uma área da ciência.

Até que finalmente, em 2005, foi lançado o curso de Ciências da Natureza pela USP ${ }^{1}$. Prestei a prova da FUVEST ${ }^{2}$ para entrar em 2006. Como era longe! Eu sempre morei em Osasco, precisava, literalmente, atravessar a cidade de São Paulo inteirinha para chegar à faculdade. Fazer isso no frio era mais dolorido ainda. Mas fui, todos os dias, sem atrasar (pelo menos não por minha culpa). Lá conheci a Prof. Dra. Rosana Signorelli com quem fiz iniciação científica por dois anos. Nessa pesquisa participei do grupo $\operatorname{DESSEC}^{3}$ na construção de um software educacional, onde contribui com a elaboração de conteúdos matemáticos.

Posteriormente, participei como bolsista ( $\left.\mathrm{PIBIC}^{4} / \mathrm{CNPq}\right)$ na construção de um portal de ensino de ciências voltado para professores de Ensino Fundamental e Ensino Médio chamado Ciência Mão, onde havia recursos didáticos, materiais, links e informações, além de

\footnotetext{
${ }^{1}$ Universidade de São Paulo

${ }^{2}$ Fundação Universitária para o Vestibular

${ }^{3}$ Desenvolvimento de Softwares Educacionais para Ciências

${ }^{4}$ Programa Institucional de Bolsas de Iniciação Científica
} 
sugestões de atividades atuando principalmente nos seguintes temas: recurso didático, filme de ficção científica, experimentos, ensino de ciências e software. Posteriormente, passei a trabalhar como estagiária bolsista da Estação Ciências da USP atuando ainda nesse portal de ensino e pude ter mais contato com professores e alunos que faziam visitações às exposições que lá eram apresentadas. Nesse período conheci meu orientador Luís Paulo, que me apresentou o filme de ficção como um recurso didático para o ensino de ciências. Com ele fiz meu trabalho de conclusão de curso onde propus o uso do filme Wall-E no ensino de temáticas de educação ambiental. Nesse mesmo período eu estava realizando meu estágio em uma escola pública da prefeitura de São Paulo, onde pude aplicar as atividades que elaborei em meu trabalho.

Nessas experiências, eu pude ter contato com os alunos em sala de aula e obter um retorno qualitativo das minhas produções, além de me interar mais sobre o meu futuro ambiente de trabalho. Entendi durante o estágio, o quanto a rotina pedagógica é corrida e cansativa tanto para os docentes como para os alunos e vi em propostas diferenciadas um recurso a mais para diversificar e auxiliar na prática docente.

Quando me formei em 2009, foi uma loucura. Estava preparando minha festa de casamento, estudando para fechar as notas dos últimos semestres, fazendo o trabalho de conclusão de curso, os relatórios de estágio, prestando concurso público para a docência e estudando inglês para entrar no programa de pós-graduação Interunidades. Não sei como, mas consegui concluir tudo isso sem deixar nada para trás.

Arrumando minhas coisas para a mudança para minha atual residência com meu marido, encontrei alguns livros da coleção Vaga-Lume. Então, me lembrei da época que ganhei o meu primeiro livro, da internet, da revolução social que foi essa inclusão forçada do mundo virtual no nosso dia-a-dia e de como os livros de literatura e as histórias em quadrinhos estiveram tão presentes em minha infância e adolescência. Senti saudades daquele tempo tão bom, das leituras instigantes e desafiadoras e de como era bom fazer parte de histórias em mundos distantes e muitas vezes impossíveis de conhecer, mas que ficaram muito próximos durante minhas leituras. Nesse momento fiquei triste em perceber que hoje, essa cultura de leitura não é tão cultivada, pois vejo todos os dias meus alunos vidrados em celulares e computadores e poucos fazendo uma leitura tão prazerosa como as minhas. Senti vontade de reler os livros da série Vaga-Lume. Nossa! Parecia que tinha sido ontem que eu os tinha lido. Rapidamente lembrei-me das histórias e cheguei a uma conclusão: o livro é atemporal. Não importa em qual época do ano você está vivendo, enquanto aquele livro 
existir, a história existirá também. Eles pediram licença para entrar em minha casa, discretos e quietos, sem cores ofuscantes, simples, sem sons a cada 5 minutos e a sensação de alegria foi total.

Percebi que não importa onde você esteja, mesmo que um dia a energia elétrica acabe, que a internet caia, o livro sempre estará lá, esperando para alguém abri-lo e lê-lo. O livro nunca sai de moda, o estilo literário nunca morre. E não creio ser diferente com essa coleção. Depois dessa leitura conversei com meu orientador de mestrado sobre a literatura e discutimos sobre a Série Vaga-Lume em especial. Compramos mais livros da série e fiz a leitura dos mesmos, foi quando me deparei com o livro $O$ caso da borboleta Atíria, que é um romance policial que me chamou atenção por abordar muitos conteúdos científicos e logo pensei em como poderia ser o seu uso em sala de aula. Acredito que esse livro também tenha me cativado por ser instigante quando a investigação está ocorrendo e ao mesmo tempo por seu acolhimento e doçura. Acolhimento por conversar com seu leitor e doçura por esperar pacientemente sem apressar o seu retorno, esperando o momento ideal que é quando abrimos o livro e mergulhamos na história que ele tem a nos oferecer. Não tive dúvidas e comecei a analisar as possibilidades que esse livro traria para o ensino de ciências.

Portanto, para análise nesta dissertação de mestrado, escolhi $O$ Caso da Borboleta Atíria por tudo que ele, como livro, possibilita a seu leitor e algumas dessas possibilidades estão apresentadas nesse trabalho. Proponho o uso da obra literária como recurso para o trabalho de questões a respeito da construção da ciência porque esse tema não é muito abordado em sala de aula devido as sua complexidade conceitual e à falta de recursos didáticos como apoio aos professores. Em minha formação pouco tempo foi dedicado ao tratamento desse conteúdo e no decorrer da minha prática docente e em conversas com professores de ciências, percebi que esse tema é essencial de ser trabalhado, porém, é visto como complexo de ser debatido. Essencial porque os conteúdos trabalhados nas aulas de ciências naturais são os resultados da construção da ciência, sendo, portanto fundamental esse embasamento inicial com os alunos.

O trabalho foi organizado em cinco capítulos, sendo que no primeiro capítulo começo falando sobre como a literatura juvenil surgiu e seus impasses em ser aceita como literatura, fazendo assim, uma contextualização histórica sobre ela e sobre a sua importância nas salas de aula e falo sobre as características da literatura brasileira. Para delimitar melhor o gênero literário (romance policial) escolhido, no segundo capítulo faço uma abordagem dos diferentes grupos de narrativas policiais, mostrando as mudanças que foram acontecendo com 
o decorrer do tempo na escrita do gênero, na caracterização do detetive, nos métodos de investigação e mostro que por atuar na esfera do raciocínio possibilita trabalhos nesse sentido.

No terceiro capítulo apresento a história do romance policial $O$ caso da borboleta Atíria, falo sobre a autora Lúcia Machado de Almeida e sua história na série Vaga-Lume. Nesse capítulo relato detalhadamente as possibilidades didáticas para o trabalho de conteúdos que fazem parte do currículo e em especial apresento as relações análogas entre a investigação científica e a investigação do detetive. Para um trabalho mais embasado com a obra realizei no quarto capítulo, uma análise semiótica e uma análise do discurso da obra. Com essas análises eu pude entender melhor o contexto político sócio econômico de produção da obra e entender para quem se destina.

A atração que sinto pela área de ensino, em especial, pelo ensino de ciências, tem me motivado desde a graduação a buscar cada vez mais recursos didáticos diferenciados para que minha prática docente seja cada vez mais eficiente e de qualidade. Acredito ser possível passar, por meio desse trabalho, a mesma fascinação que tive e tenho pela literatura. 


\section{CAPÍTULO 1: LITERATURA INFANTO-JUVENIL E ENSINO DE CIÊNCIAS}

A proposta do trabalho com a literatura infanto-juvenil no Ensino de Ciências surgiu a partir de leituras sobre esse tema, que mostram os benefícios e quão poucos são os trabalhos nessa área. Dentre as leituras sobre os benefícios proporcionados pela literatura encontramos autores que falam sobre temas diversos como, adolescência, cultura, formação de leitores, promoção da leitura, entre outros temas (COLOMER, 2003; SILVA, 2009; GREGORIN FILHO, 2011; FERNANDES, 2007). Como exemplos de professores e pesquisadores que incorporam a literatura e outros recursos didáticos no Ensino de Ciências, temos Zanetic (2005) que nos mostra as relações existentes entre arte e ciência, Resende (2000) que apresenta diversas propostas de atividades em sala de aula com o uso da literatura e em outro trabalho (RESENDE, 1983) traz relatos de experiências na escola, com uso de gêneros literários diversos. Há também exemplos com o uso de poemas (COELHO, 1993; MOREIRA, 2002; RESENDE, 1983), contos (PIASSI, 2007; RAMOS, 2012), filmes (MACHADO, 2008; SANTOS, PIASSI, VIEIRA, 2009; SANTOS, 2009) e histórias em quadrinhos (DANTON, 2005; NASCIMENTO, 2013). A partir das propostas de tais autores notamos que o uso da obra de literatura no ensino de temáticas diversas geram interesse e motivação nos estudantes. $\mathrm{Na}$ abordagem de temas científicos, observamos a formação de hábitos e atitudes positivas em relação à Ciência causadas pela obra de ficção.

Diversos são os benefícios gerados pelo uso da literatura, entre eles os de cunho educacional, como melhor desenvolvimento da leitura, escrita, oralidade e o estímulo ao debate. Em relação aos benefícios transversais, notamos que a leitura estimula a sensibilidade, a capacidade crítica e senso estético, para melhor compreensão do mundo e de si mesmo. Também pensamos nessa proposta como uma ideia diferenciada, que pode ser utilizada como um recurso na inserção de temas científicos no Ensino de Ciências no Ensino Fundamental I e II que compreende do $5^{\circ}$ ao $9^{\circ}$ ano ( $4^{\circ}$ à $8^{\circ}$ série).

Zanetic (2005, p. 22) nos mostra que o uso da arte por cientistas para divulgar suas descobertas ou expressar suas ideias não é recente. Ele cita exemplos como o poema $O s$ lusíadas, de Camões, que sofreu influência aristotélico-ptolomaica; as obras do poeta e professor de ciências John Milton que apresentou em sua escrita às visões do mundo geocêntrico aristotélica e a heliocêntrica copernicana, que estavam em pauta na época. Também fala de Milton que sofreu influencias do Renascimento e que em seu poema $O$ 
paraíso perdido, publicado em 1667, relata "sua visão religiosa, política, social e científica do mundo". Newton é outro exemplo, que influenciado pelas descobertas de Galileu e por suas próprias ideias de gravidade, escreveu a novela Sonho ou astronomia da Lua, onde ele descreve "em Sonho uma viagem à Lua". Por meio desses exemplos e de muitos outros, Zanetic (2005, p.23) ressalta que "as operações culturais desses dois campos do conhecimento - literatura e ciência - acabam se cruzando e, talvez, apresentando uma certa complementaridade de construção sobre a realidade" mostrando que há poetas com veia científica e cientistas com veia literária e tais produções podem e devem ser utilizadas no ensino de conteúdos que fazem parte do currículo, possibilitando muitas vezes trabalhos interdisciplinares (ZANETIC, 2005, p. 22).

Dentre as diversas temáticas que fazem parte do currículo de ciências, propomos a utilização do livro de literatura no debate da investigação científica, ou seja, a maneira como a Ciência é construída, tema que muitas vezes não é abordado em sala de aula. Acreditamos que o romance policial seja um dos gêneros literários mais apropriados, porque mesmo sendo uma ficção, constitui um jogo de imaginação, que se utiliza dos processos fundamentais da razão, ou seja, o leitor se coloca na trama como um ser pensante com o intuito de desvendá-la, por meio das pistas fornecidas pelo autor. No romance policial, o enigma torna-se um crime misterioso, gerando prazer em quem lê.

Pensamos em uma analogia da ciência, em que o cientista transforma-se em detetive para descobrir o enigma. É possível assim perceber as ligações existentes entre os dois e as possibilidades múltiplas de abordá-los. Para abordar esse tema, nada melhor do que um romance policial, pois assim como dito por Boileau-Narcejac (1991, p. 12). "O romance policial é o modelo muito aperfeiçoado da investigação científica". Isso porque o romance policial é dotado de características que se aproximam do mundo da investigação científica, de como a ciência é construída.

Este trabalho tem como obra modelo $O$ caso da borboleta Atíria de Lúcia Machado de Almeida que foi escolhida por ser um romance policial que está presente nas salas de aula e bibliotecas escolares como livro paradidático até os dias de hoje. Essa obra foi concebida em especial para o público jovem, que poderá lê-la tanto no espaço escolar como fora dele, assim como para os professores, que são os mais interessados no seu uso em sala de aula. Segundo Borelli (1996), a obra agrada não somente o público infanto-juvenil como também aos professores e isso se deve à sua criação, que é voltada para a escola de ensino formal. Além do mais, possui qualidade, grande tiragem e apresenta conteúdos científicos com uma 
linguagem acessível aos alunos.

Mas por que a proposta do uso de uma obra literária no ensino da investigação científica? Além dos motivos já citados, sabemos que a vida corrida e cada vez mais dependente da tecnologia está modificando a visão do homem de forma tão invasiva, que reduz seu olhar filosófico, tendo como consequência a perda do hábito de aprender e pensar os problemas existenciais da humanidade. Acreditamos que a leitura de obras literárias recoloca o leitor na condição de ser pensante e reflexivo e resgata a consciência de sua humanidade e de sua compreensão enquanto ser no mundo.

Quando se pensa no uso da literatura no ensino, geralmente se pensa na disciplina de Língua Portuguesa. Porém, muitos livros que não são direcionados ao Ensino de Ciências e que podem ser utilizados com essa finalidade, afinal, muitas obras literárias são escritas por escritores interessados nos resultados da ciência. Esses resultados estão presentes no dia-a-dia de todos e o fato da ciência fazer parte do mundo, faz com que ela também faça parte do mundo do escritor infanto-juvenil.

Segundo Linsingen (2008), esse interesse resulta em sensações de temores e esperanças que muitas vezes se transformam em ficção. Uma vez que a ficção tem a capacidade de incidir na emoção das pessoas, Waal (2007 apud LINSINGEN, 2008, p. 6) defende que as emoções fazem com que as pessoas não se coloquem de forma indiferente perante as informações, fazendo com que fiquem retidas na memória do leitor. Por esta razão, a obra literária pode ser usada como um recurso didático, que poderá atuar nas emoções das pessoas, possibilitando ao professor a abordagem de conteúdos de ensino por meio dela (LINSINGEN, 2008).

Com base nisso, Linsingen (2008, p. 3) ressalta que:

\footnotetext{
Entendendo o ser humano, e, sobretudo, a criança e o adolescente, como um sujeito em formação, e entendendo a cultura como uma série profusa e complexa de fazeres e saberes na qual estamos mergulhados mesmo antes de nascermos, não faz sentido desmerecer uma expressão literária em detrimento de outra. Mais ainda, se pensarmos que nenhuma obra humana é isolada, que cada criação do Homem é um reflexo da realidade que o circunda, e ao mesmo tempo um diálogo com este contorno, então é razoável pensar a Literatura Infantil em um contexto como o Ensino de Ciências.
}

No decorrer da leitura, a cumplicidade do leitor com o conteúdo vai aumentando e a partir disso, ele vai tomando consciência de que, ao escrever, o autor concebeu um projeto de comunicação. Em sua produção, o autor, com maior ou menor margem de manobra, tem a 
possibilidade de manipular restrições e liberdades linguísticas conforme a sua finalidade textual.

A esse respeito Silva e Martins (2010) dizem:

\begin{abstract}
Ler é estabelecer relações; trata-se de tentativas de retomar os sentidos pretendidos pelo autor em meio à configuração textual. Nessa perspectiva, a leitura não está nem no texto, nem fora dele. Trata-se de um espaço de interlocução entre aquele que escreve e aquele que lê, mediado pela estrutura textual. Se, de fato, o sentido não reside no texto a priori, então é preciso convocar os sujeitos para as múltiplas leituras possíveis. Ler consiste, portanto, em exercer uma tarefa (SILVA e MARTINS, 2010, p. 28)
\end{abstract}

A importância da leitura no processo de ensino e aprendizagem de um estudante é de real e indiscutível importância, por aperfeiçoar seu desempenho em toda e qualquer disciplina, e também em sua vida pessoal. Ao entrar em contato com o mundo das ideias e das informações, amplia-se sua área de conhecimento. Além da significativa contribuição que a literatura pode proporcionar ao ensino, no plano da educação geral, pensamos que ela proporciona também uma capacidade crítica para melhor compreensão do mundo e de si mesmo. Porém, o uso da literatura será eficaz apenas se os mediadores (professores) receberem a formação adequada para o seu uso.

É importante ressaltar neste trabalho, o papel desempenhado pelo professor de mediador do conhecimento, que está situado entre o recurso didático e o aluno, portanto, ele direciona o olhar dos alunos para um objetivo pedagógico, sem deixar de se atentar às capacidades cognitivas individuais dos alunos. Haja vista que a literatura traz uma gama de possibilidades, o seu uso deve ser cada vez mais incentivado e pesquisas nessa área devem ser mais realizadas e difundidas.

Sendo assim, o objetivo principal desse trabalho é propor o debate da construção da ciência em sala de aula por meio da literatura policial, abordando a maneira como a ciência é construída, de forma diferenciada, utilizando o livro como um recurso didático diferenciado dos utilizados rotineiramente no dia-a-dia escolar, como livros didáticos. Para a utilização da obra literária infanto-juvenil em sala de aula, apresentaremos propostas didáticas para a realização de discussões acerca de algumas visões epistemológicas da investigação científica, através da literatura de Popper, Kuhn, Feyerabend e empirismo.

No decorrer do trabalho, apresentamos a análise semiótica e do discurso da obra estudada, assim como, diversos conteúdos que nela estão presentes com o intuito único de conhecer melhor a obra e mostrar as vastas possibilidades de seu uso, porém, ressaltamos que 
o intuito central é mostrar que é possivel um trabalho com o romance policial sobre conteúdos relacionados à construção da ciência. Sendo assim, iniciaremos relatando no próximo capítulo as vatagens e características da obra de literatura juvenil que fazem desse recurso um parceiro para o professor em suas aulas.

\subsection{LITERATURA JUVENIL}

O nascimento da literatura infantil e juvenil como fenômeno cultural ocorreu no século XVIII. Conforme Teresa Colomer (2003, p.23), no decorrer do período entre guerras deste século surge uma reflexão crítica sobre este material e o início de um desenvolvimento editorial acerca da literatura.

No início do século XVIII houve um incentivo à ampliação da alfabetização para todas as camadas sociais, porém, a escola ainda estava nesse período focada em uma leitura formativa. Com o decorrer do tempo, mudou a visão dos meios bibliotecários a respeito da leitura e estudos referentes à literatura infantil e juvenil começaram a surgir. Em algumas regiões houve crescimento na produção de produtos voltados para a infância devido à existência de uma rede descentralizada de bibliotecas públicas. Essa difusão da leitura voltada para a fase infantil teve início nas bibliotecas britânicas e norte-americanas, posteriormente nas francesas e nas do norte da Europa. A preocupação com a formação literária infantil foi tão grande que foram fundadas bibliotecas infantis experimentais como forma de incentivo à esse tipo de leitura para o público infanto-juvenil (COLOMER, 2003, p.23).

Em 1880 surge pela primeira vez, uma sala de leitura voltada para crianças. Tais salas foram crescendo em número nos Estados Unidos da América, e em paralelo cresceu também a difusão de edições americanas. Tal crescimento espalhou-se por outros países, ocasionando no período entre guerras, mais precisamente em 1918, a formação em Nova York de um comitê voltado para livros infantis, assim como, novas bibliotecas de livros infantis. A primeira surgiu em Bruxelas no ano de 1920 e outra foi criada em Paris, no ano de 1924. Paralelamente a isto, cresceram os estudos nesta área e nomes como, Sara Cone, May Hill Arbuthnot, Paul Hazard, entre outros, se consagraram como grandes autores (COLOMER 2003, p.24).

Esta tendência continuou crescendo após a Segunda Guerra Mundial em diversos países, ocorrendo em 1949 a criação da Biblioteca Internacional de Munique por Jella Lepman, se tornando um local de grande promoção da literatura infantil e juvenil. Organizações desse tipo foram crescendo cada vez mais com o passar do tempo, como a 
IFLA $^{5}$ e nos EUA o Centro de Literatura Infantil da Biblioteca do Congresso (COLOMER 2003, p.25).

Segundo Colomer (2003), todo esse movimento bibliotecário e as renovações pedagógicas elaboradas produziram dois discursos: o de incentivo à leitura de materiais utilizados pela burguesia que se aproxima de um discurso típico da escola, e o de incentivo também a uma literatura "livre e funcional, nos objetivos do ensino". Esses discursos produziram movimentos diferentes, surgindo em 1953, em Zurique, o IBBY ${ }^{6}$ (Organização Internacional para o livro Infantil e Juvenil), também criado por Jella Lepman. Essa organização adquiriu dimensões internacionais ao se associar com a $\operatorname{UNESCO}^{7}$ e com a $\mathrm{UNICEF}^{8}$, estando presente atualmente em mais de sessenta países, se mantendo associada internacionalmente a diversas outras associações voltadas para a literatura infanto-juvenil (COLOMER, 2003, p. 26).

Conforme dito, a princípio os estudos sobre a literatura infanto-juvenil surgiram com o intuito de selecionar, classificar e difundir tais livros. A partir disso, surge um questionamento sobre quais obras deveriam ser inseridas nesta literatura. Conforme Colomer (2003, p.28), a partir de pesquisas históricas sobre a instauração desta literatura, países como os anglo-saxões e os nórdicos superam de forma significativa outros países tanto qualitativamente como quantitativamente na produção literária infanto-juvenil, enquanto os outros ainda estavam iniciando essa jornada de pesquisa e produção.

Os estudos sobre o que seria a literatura infantil e juvenil perpassam por algumas discussões, como se os livros infantis pudessem ser considerados literatura; se a caracterização da obra deveria ser feita com base em sua qualidade ou pelo sucesso que alcançava; ou se sua definição deveria ser feita admitindo que ela se tratava de um campo literário específico inserido em um sistema de comunicação literária (COLOMER, 2002, p. 43).

Colomer (2003, p.43) diz que diversos são os autores que negam se tratarem de obras de literatura os textos que são produzidos para o público infantil e juvenil. Dentre eles estão Sánchez Ferlosio, Benedette Croce, Rico Alba, entre outros, que dentre seus argumentos dizem que a arte literária necessita de maturidade para ser apreciada e que a literatura infantil, além de não obter isso de seu leitor fere normas de qualidade utilizadas na produção da

5 Federação Internacional de Associações de Bibliotecas

6 International Board on Books for Young Peoples

7 Organização das Nações Unidas para a Educação, a Ciência e a Cultura

8 Fundo das Nações Unidas para a Infância 
literatura.

A partir de confrontos de posicionamentos como estes, a literatura infanto-juvenil passou a ser considerada uma literatura menor por alguns. Com o intuito de reverter tal visão, os defensores dela procuraram apresentar as "marcas de 'literariedade' nos textos para crianças" com o intuito de mostrar suas características que a tirassem de tal esteriótipo (COLOMER, 2003, p. 44 apud POSLANIEC, 1990). Percebemos que tal discussão é grande e que possui adeptos com pensamentos distintos, pois há os que a veêm como uma literatura menor que não pode ser comparada com obras literárias. Mas em contrapartida, também há os defensores da literatura infanto-juvenil como literatura de qualidade, que possui apenas públicos distintos.

\subsubsection{Histórico da Literatura Juvenil brasileira}

Com a vinda da família real para o Brasil, a instituição escolar brasileira se fundamentou nos padrões europeus. Gregorin Filho (2011) mostra que o Brasil seguia "os padrões de intelectualidade e estética literária aceita pelos europeus, conveniente para a sociedade portuguesa". Isso compreende o período que ia desde os trabalhos dos jesuítas até o final do século XVIII. A literatura infanto-juvenil começou a se expandir a partir do século XIX na Europa e consequentemente, textos traduzidos em Portugal passaram a aumentar em sua colônia, o Brasil. Tais textos continham elementos culturais das sociedades europeias. Esse cenário mostra um ciclo de dominação, onde Portugal segue ideologias de nações poderosas como França e Inglaterra e consequentemente, o Brasil seguia seus modelos e costumes (GREGORIN FILHO, 2011, p. 27).

Portugal apresentou tentativas de se libertar dos modelos europeus e o mesmo passou a ocorrer no Brasil, tentando se soltar das amarras ideológicas importadas por Portugal, e passou a inserir em suas obras contribuições de outras culturas, a fim de produzir uma identidade cultural própria (GREGORIN FILHO, 2011, p. 30).

Esse histórico mostra que a literatura juvenil (ou de um modo geral) vincula as práticas sociais em que está inserida. A partir do momento em que a escola passou a ser a responsável pela educação, na segunda metade do século XIX, a literatura juvenil sofreu mudanças históricas e dialógicas, apresentando em sua escrita: 
A diversidade de valores do mundo contemporâneo; o questionamento do papel do homem diante de um universo que se transforma a cada dia; as vozes de diferentes contextos sociais e culturais na formação do povo brasileiro, sua diversidade e dificuldade de sobrevivência; e, o mais importante, as vozes e sentimentos do adolescente nas páginas dos livros, nas ilustrações e nas diferentes linguagens que compõe a produção artística para os jovens (GREGORIN FILHO, 2011, p.32).

Os textos passaram a ser dialógicos, abrindo espaço para a voz questionadora do jovem, tendo as obras de Lobato como marco para tais mudanças. No início da década de 40, mudanças drásticas aconteceram no mundo, como a II Guerra Mundial e o Holocausto. Os valores começaram a desaparecer meio a esses conflitos. Ocorreu então, a expansão da literatura em quadrinhos, que possuía histórias de aventuras e super-heróis, percorrendo temas maravilhosos e científicos. (GREGORIN FILHO, 2011, p. 33).

Com as reformas feitas no ensino, a partir de 1942 por Gustavo Capanema, a iniciação cultural era voltada para a prática de valores e para a formação do cidadão. Neste período, as obras de Monteiro Lobato passaram a ser proibidas nos colégios religiosos, trocando o literário pelo didático. Nas obras de literatura juvenil houve um aumento de documentários, de temas voltados para a natureza e temáticas sobrenaturais com a presença de super-heróis. Nas escolas eram utilizadas de forma bem incisiva a "literatura rósea", de cunho romântico, principalmente pelas mulheres (GREGORIN FILHO, 2011, p. 34).

$\mathrm{Na}$ década de cinquenta vivia-se uma crise de leitura, pois diminui a produção da literatura aumenta a falta de interesse dos jovens pela leitura. Nesse período também surgiu a televisão com produções artísticas diversas de altíssima qualidade, fator este que fez com que a leitura fosse deixada de lado. Foi nesse período em que as obras de Lúcia Machado de Almeida, como As Aventuras de Xisto e a obra analisada neste trabalho foram produzidas. No início da década de sessenta, mais precisamente, em 1961, surgiu na $\operatorname{LDB}^{9}$ a lei 4.024 voltada para a democratização do ensino, que em meio a questões políticas e econômicas, não se concretizando rapidamente. A leitura "passou a ser vista como apoio para atividades de aprendizagem, devendo ser a ferramenta para promover o enriquecimento do vocabulário e a compreensão do significado das palavras" (GREGORIN FILHO, 2011, p. 36).

Manifestações artísticas como música e teatro ganharam força nesse cenário político, sendo que, a literatura não emplacou tanto por causa da repressão utilitarista. Com isso, poucos foram os escritores de literatura brasileira. Já nas décadas de 70 e 80, a literatura juvenil voltou a emplacar, tratando em seus enredos os conflitos dos jovens nesse novo 
contexto social. Destacaram-se nesse momento, autores como Lygia Bojunga e José Mauro de Vasconcelos, com escritas que propunham diálogos e não imposições, apresentando também a voz do jovem (GREGORIN FILHO, 2011, p.38).

No ano de 1990, por meio da Lei $\mathrm{n}^{\circ} 9.394$ da LDB, juntamente com os $\mathrm{PCN}^{10}$, temas transversais considerados como tabus passaram a ser debatidos na literatura juvenil. Dentre eles estão, a sexualidade, a pluralidade cultural e questões étnico-raciais (PCN, 1999, p. 39). Nesse mesmo viés, foi promulgada em 2008 a Lei ${ }^{\circ}$ 11.645, que:

(...) tornou obrigatória a inclusão, no currículo de estabelecimentos de ensino fundamental e médio, o estudo da história e cultura afro-brasileira e indígena, visando resgatar as contribuições desses povos nos campos social, econômico e político. A lei prevê a inserção desses temas em toda a estrutura curricular, particularmente nas áreas da educação artística, história e literatura brasileiras (GREGORIN FILHO, 2011, p.39).

As questões multiculturais apareciam com o intuito de proliferar a visão de que se vive meio a uma grande diversidade social em vários setores. $\mathrm{O}$ narrador de literatura juvenil buscava criar um leitor crítico, consciente do que o cercava e que buscava apresentar uma identidade brasileira, mostrando aspectos étnicos e de pluralidade cultural. Vemos então, a construção de uma arte literária que estava presente no processo educativo do jovem, sem deixar de explorar a pluralidade brasileira. Notamos que o cenário mudou, a literatura deixou de veicular exclusivamente padrões estéticos de outras culturas com valores moralizantes, passando a mostrar as manifestações artísticas brasileiras (GREGORIN FILHO, 2011, p. 41).

\subsubsection{Literatura Contemporânea Brasileira}

Segundo Gregorin Filho (2011, p.41), na contemporaneidade temos uma literatura juvenil rica em seus diálogos, que apresenta a realidade sociocultural brasileira e que não tem o objetivo único de veicular padrões estéticos e de conduta de outras culturas, como acontecia anteriormente.

O autor mostra também que:

\footnotetext{
A literatura feita para o jovem da atualidade está vinculada à arte, isto é, ao mesmo tempo em que traz à tona as discussões de valores sociais, devolve para a sociedade novas maneiras artísticas de discutir e veicular esses valores, seja por meio de múltiplas linguagens, seja por intermédio das atuais formas de suporte para que essa arte seja veiculada (GREGORIN FILHO, 2011, p.41).
} 
José Nicolau explica que há dois momentos significativos para a concepção da atual literatura, sendo eles, a década de vinte e o período pós Segunda Guerra Mundial. Nos anos vinte houve a Semana de Arte Moderna que suscitou mudanças na arte, buscando sua modernidade. Nesse período a maioria dos livros eram de cunho pedagógico. Surgiu então Monteiro Lobato, com livros que,

(...) suscitaram reações bem acaloradas, dados o pensamento tradicionalista no ensino e a manutenção do cenário conservador, com a maioria dos livros destinados à literatura literária na escola guardando, ainda, o caráter absolutamente pedagógico de épocas anteriores (GREGORIN FILHO, 2011, p.42).

Nos anos quarenta as histórias em quadrinhos viraram mania e nos anos cinquenta, houve um aumento da produção cultural voltada para os jovens, por meio da criação de filmes e de novos ritmos musicais vindos de toda parte do mundo. Houve um aumento das produções de histórias em quadrinhos, que viram na fase de rebeldia dos adolescentes, um bom mercado. Meio aos confrontos armados da época, a rebeldia veiculada pela produção cultural norte americana ganhou espaço, em oposição aos padrões de moralidade aceitos na época pela educação brasileira (GREGORIN FILHO, 2011, p. 43).

Com isso, as produções culturais das instituições escolares passaram a negar os jovens, em especial por meio da literatura. Tais instituições não aceitavam os novos padrões estéticos voltados para a literatura e acabavam criando propostas que se distanciavam cada vez mais dos alunos. Essas negações de forma autoritária acabaram incentivando reações por parte dos jovens, tendo como exemplo, o movimento Tropicália que por volta dos anos sessenta confrontava as imposições da ditadura. Nesse momento o "rock-and-roll" foi muito consumido e os livros didáticos passaram a sofrer influências da estética das histórias em quadrinhos (GREGORIN FILHO, 2011, p. 44).

Nos anos setenta surgiu uma gigantesca produção própria para crianças e jovens, e com isso, houve um aumento do número de novos autores, tendo como exemplo João Carlos Marinho e Odette de Barros Mott que disseminaram meio a censura, questões importantes da época e da realidade cotidiana. Na contemporaneidade, obras como $O$ Senhor dos anéis de J. R. R. Tolkien e Harry Potter de J. K. Rowling, que apresentavam em suas escritas o maravilhoso, passaram a ser muito consumidas pelos leitores juvenis. Essas leituras combateram a ideia de que o jovem não lê uma quantidade grande de páginas, pois tais obras eram bem extensas (GREGORIN FILHO, 2011, p. 44).

A partir do que foi apresentado percebemos que a literatura juvenil sofreu diversas mudanças com o passar do tempo, porém, vemos que apesar de todas as influências estéticas, 
culturais, sociais, entre outras, ela não se desvinculou da escola.

Conforme Vera Maria Tieztmann, (2009, p. 38) a literatura juvenil é uma invenção recente que serve de ponte entre a literatura infantil e a leitura de obras adultas. Seu crescimento ganhou mais força porque a leitura está associada ao ambiente escolar, favorecendo o aumento da produção editorial de livros infantis e juvenis. Ela também aborda alguns fatores que acabam interferindo "no percurso do leitor em formação" sendo dois deles a ponte feita entre a leitura e a escola, que cria uma falsa visão de que a leitura deixa de ser feita visando o prazer e passa a ser realizada pelo dever; e a o atual cenário cultural em que vivemos "cercado por um bombardeio constante de sons e de imagens". Isso faz com que os jovens se acomodem e não dediquem mais de seu tempo à leitura.

Vera Maria Tieztmann explica esse cenário ao dizer:

\begin{abstract}
Para o comodismo de hoje, com jovens habituados ao imediatismo das imagens trazidas instantaneamente às telas da televisão, dos computadores e dos jogos eletrônicos, os livros de aventura que seduziam a imaginação de seus pais e avós parecem fastidiosos de tão longos. O fôlego de nossos jovens anda curto, sua paciência também. As diversões eletrônicas, os 'shoppings centers', a vida noturna, a prática de esportes, a malhação nas academias são atividades que encurtam o tempo que poderia ser despendido com uma leitura de prazer.

(...) É com essa limitação que temos que enfrentar o problema de como propiciar ao adolescente escolar um passaporte de leitura para a vida adulta (SILVA, 2009, p. 38).
\end{abstract}

Outro ponto interessante abordado por Vera Maria Tieztmann (2009) são as mudança que aconteceram com o desenvolvimento da leitura com o decorrer do tempo. Ela mostra que o ato de ler não é muito cultivado nas sociedades atuais, diferentemente dos leitores do passado, que começavam suas leituras com histórias em quadrinhos e revistas infantis, passando por Lobato e chegando a obras de grandes escritores sem dificuldades de entendimento. Já o leitor atual não consegue fazer esse percurso de forma simples, e talvez isso possa se dar por causa das mudanças dos hábitos de leitura dos leitores atuais (SILVA, 2009, p. 38).

Sabemos que a leitura é um percurso que flui de algo mais simples para uma leitura mais elaborada, e isso se dá quando o leitor aprimora e exercita sua leitura. Além disso, há diferenças entre os diferentes tipos de leitura, como o formato e a utilização de ilustrações entre outros fatores que acabam caracterizando o público para o qual a literatura é destinada. A esse respeito, Silva (2009, p. 39) diz que:

Daí a complexidade crescente dos textos, segundo a idade de seus destinatário. Extensão, estrutura e temas abordados relativizam-se e dimensionam-se de acordo com a maturidade de seu leitor potencial. As publicações para os muitos pequenos são facilmente identificáveis seu formato, material, ilustração, antes mesmo de se conferir o que dizem. Quanto maior o percurso percorrido pelo leitor, mais o texto se 
estende e a ilustração rareia. Aproximando-se do limiar da prontidão para a complexidade das obras literárias, chega-se a um ponto onde já não se distinguem as diferenças entre o juvenil e o adulto (SILVA, 2009, p. 39).

Pensando nisso, surge o seguinte questionamento: Há temas que são exclusivos e podem ser caracterizados como temas que devem ser abordados apenas em uma determinada faixa etária, "infantil", “juvenil” e "de adultos"? Silva mostra que as editoras e os autores produzem seus livros tendo como modelo um leitor ideal, em que "o crescimento físico e etário corresponde ao crescimento intelectual e psíquico", porém, na realidade atual, percebemos que constantes são as adequações feitas pelos professores para que seus alunos consigam acompanhar a leitura do nível de ensino em que estão devido a sua defasagem (SILVA, 2009, p. 39).

Também acontece de leituras mais elaboradas serem apreciadas e entendidas por leitores de um nível intelectual para a qual ela não é destinada. Sendo assim, as editoras têm investido cada vez mais na qualidade dos livros com o intuito de ganhar mais leitores e o fato da leitura estar atrelada á vida escolar fez com que melhorasse a qualidade dos livros, pois houve um aumento da produção editorial gerando concorrência entre as editoras.

\subsubsection{Literatura Juvenil na escola}

O acesso à literatura se dá conforme as condições sociais do indivíduo. Alguns ganham livros desde pequenos, quando ainda nem mesmo sabem ler, onde a leitura é feita por meio das imagens e da contação de histórias por parte dos adultos. Entretanto, de maneira geral, na escola todos passam a ter acesso a um leque de obras literárias que começam a fazer parte do dia a dia dos alunos. Conforme Silva e Martins (2010, p.26), à escola está reservado o papel de "promover o ensino da leitura e da escrita", sendo a "agência de letramento das mais importantes". E na escola há figura do professor como mediador desse letramento, afinal, conforme dito por Zanetic (2005) "todo professor, independente da disciplina que ensina, é professor de leitura". Porém, cabe ressaltar que a leitura deve ter significado para o aluno, pois como dito por Paulo Freire (2001, p. 18) “o comando da leitura e da escrita se dá a partir de palavras e temas significativos à experiência comum dos alfabetizados e não de palavras e de temas apenas ligados à experiência do educador".

Sobre o porquê da leitura na escola e sobre como ela deve ser feita, Silva e Martins 
(2010) dizem que:

Leríamos na escola, espaço de produção cultural, para ocuparmos o lugar de sujeitos, para questionarmos os sentidos colhidos nas configurações textuais e propor-lhes outros sentidos... Leríamos estabelecendo relações com as experiências herdadas da vida em sociedade, arriscando alcançar além do nosso conhecimento de mundo (SILVA e MARTINS, 2010, p. 29).

Essa leitura crítica e contextualizada também é ressaltada por Paulo Freire (2001, p. 9, 13) ao dizer que "a leitura de mundo precede a leitura da palavra e a leitura desta implica a continuidade da leitura daquele" e que "a compreensão do texto a ser alcançada por sua leitura crítica implica a percepção das relações entre o texto e o contexto".

Para a utilização da literatura em sala de aula, Gregorin Filho (2009) fala sobre alguns pontos que devem ser observados, dentre eles:

\footnotetext{
- entender a literatura como um fenômeno de linguagem que resulta de experiências sociais e culturais vivenciadas pelos autores;

- valorizar as relações existentes entre literatura, história e cultura, pois cada momento histórico e cada cultura criam uma estética própria para o fazer literário; -compreender a leitura como diálogo entre leitor e texto, entre contextos -integração entre o momento da leitura (presente) e o da produção textual (passado); - perceber a variedade de linguagens e suportes textuais... sabendo que o papel principal da escola é partir da linguagem iconográfica para a verbal;

- entender o espaço escolar como aquele em que podem ser desenvolvidas as primeiras relações do indivíduo com a sociedade, espaço responsável pelas primeiras lutas e pelas primeiras conquistas (GREGORIN FILHO, 2009, p. 75).
}

A partir disso, percebemos que a literatura é um grande veículo para tais discussões, pois conforme Gregorin Filho (2009), ela é a expressão máxima da arte e da alma de um povo. Cabe ressaltar também que cada gênero possui suas especificidades de trabalho em sala de aula e o professor tem que ter em mente o seu objetivo com o uso da obra literária, buscando entender a melhor forma de utilização do gênero que escolheu.

A esse respeito, Silva e Martins (2010, p. 32) ressaltam que há uma gama gigantesca de gêneros literários em circulação na sociedade e que dependendo do contexto e do objetivo, para uma melhor organização do trabalho do professor, a escolha da obra literária deve ser feita de forma cuidadosa, sendo a escolha do material um importante passo a ser considerado, avaliado e planejado. Acrescentam que:

O papel do professor e de outros mediadores da leitura é fundamental desde o momento da selação dos textos e materiais de leitura - em diferentes suportes (livros, revistas, jornais, recortes, cartas, e-mails, blogs, cartazes, panfletos, bulas, etc.) e numa diversidade de gêneros (literários, jornalísticos, científicos, publicitários, epistolares, etc.). Qualquer que seja o nível da turma com que se trabalhe, o planejamento da leitura e, dentro dele, a organização do tempo pedagógico para as atividades de leitura são peças-chave para o bom resultado do trabalho do professor (SILVA e MARTINS, 2010, p. 33). 
Quando se pretende trabalhar o mesmo gênero ou obra em salas de aulas diferentes e com alunos com características diferentes, devemos pensar que:

\begin{abstract}
A utilização em uma ou mais série deverá ser precedida de uma avaliação diagnóstica para que se verifiquem as reais condições de leitura e o amadurecimento do aluno para tal atividade, dentre outros fatores. Em caso de classes com diferentes tipos de leitor (por exemplo, com portador de deficiência), pode ser necessário um trabalho direcionado a pequenos grupos (GREGORIN FILHO, 2009, p. 78).
\end{abstract}

Quando se trabalha um texto narrativo, os alunos passam a descobrir os elementos estruturais dessa narrativa, que são importantes para a compreensão do "enredo, como personagens, espaço, tempo, ações, entre outros", proporcionando o estabelecimento de uma inter-relação entre o microcosmo do texto literário e o macrocosmo, que nada mais é que o contexto social em que o aluno está inserido. Pensando nisso podem ser propostas atividades com o intuito de que a partir da observação da obra de arte sejam pensadas questões do mundo que rodeia os alunos leitores (GREGORIN FILHO, 2009, p. 76).

Ao se trabalhar com a literatura em sala de aula, criamos:

Condições para que se formem leitores de arte, leitores de mundo, leitores plurais. Muito mais do que uma simples atividade inserida em propostas de conteúdos curriculares, oferecer e discutir literatura em sala de aula é poder formar leitores, é ampliar a competência de ver o mundo e dialogar com a sociedade (GREGORIN FILHO, 2009, p. 77).

Outro ponto interessante do trabalho com o uso da literatura nas escolas é que muitas obras, além de trazerem uma linguagem artística que estimula a imaginação do aluno, muitas vezes também trazem conteúdos que fazem parte do currículo escolar e podem ser trabalhadas de forma interdisciplinar pelos professores, assim como é proposto nesse trabalho com o uso da obra $O$ caso da borboleta Atíria. Dessa forma, a literatura alcança diversos resultados, possibilitando o incentivo à leitura, a criação de atividades diferenciadas, o ensino de conteúdos que fazem parte do currículo e temas transversais, ampliando-se o projeto pedagógico da escola, ao trazer maiores possibilidades com o seu uso.

A escolha do gênero romance policial se deu por ele possuir características que possibilita ao leitor estabelecer relações entre a história do detetive com a pesquisa do cientista. As características e a história desse gênero literário será apresentada no capítulo seguinte, asssim, o leitor poderá no decorrer da leitura da obra observar os aspectos que a diferencia de outros gêneros. 


\section{CAPÍTULO 2: ROMANCE POLICIAL E INVESTIGAÇÃO}

\subsection{INTRODUÇÃO}

Boileau-Narcejac (1991, p.12) questiona o fato de Edgar Allan Poe ser o singular merecedor do reconhecimento pela criação do gênero romance policial. Segundo ele, o romance policial existe porque os humanos no geral são seres pensantes, com um intelecto que escapa às limitações do espaço e do tempo. E que almejam extrair, de qualquer forma, o inteligível do sensível.

O romance policial parece ter-se constituído pouco a pouco, em uma época relativamente recente. É apenas uma aparência. Os mecanismos da razão que ele emprega são contemporâneos do próprio homem... Poe não forjou o romance policial. Divulgou-o, ajudado pelas circunstâncias (BOILEAU-NARCEJAC, 1991, p.12).

De qualquer forma, Poe (1809-1849) foi genial ao divulgar o romance policial, como tal, primeiro com a publicação do conto The murders in the Rue Morgue (O assassinato na rua Morgue), em 1841, sob a forma de folhetim. Podemos dizer que com Edgar Allan Poe nasceu a escola policial clássica, pois ele possibilitou o surgimento de outros tipos de narrativa policial que serão apresentados neste trabalho (BOILEAU-NARCEJAC, 1991).

A narrativa policial, ou romance policial, também é conhecida por narrativa policial de detetive ou romance de enigma. A caracterização de uma narrativa policial não é tão simples. Neste tipo de narrativa há os elementos, crime, delito e alguém com a intenção de desvendálo, porém, a presença de tais elementos em uma narrativa não podem classificá-la como policial, pois, além disso, a narrativa deve ser articulada de uma forma específica que a caracteriza com tal. No romance de enigma, o enigma é o desencadeador da narrativa, sendo a sua elucidação o encerramento da narrativa. Sobre o do romance policial, Marisa Lajolo (2004) diz,

No romance policial - tão mal-amado pela crítica -, o leitor é empurrado para a posição de detetive. E este leitor- Sherlock me parece um emblema feliz do bom leitor do bom romance: sigo pistas, imagino situações, desmancho álibis. Tudo para chegar a verdade. Verdade com maiúscula que - o gênero garante - me espera na última página do livro. Lá estão as respostas a todas as perguntas. Não é para isso mesmo que servem os romances? (LAJOLO, 2004, p.25).

Para que haja o entendimento do surgimento desse gênero, primeiramente apresentaremos os pensamentos e as propostas levantados por Edgar Allan Poe em relação ao 
gênero policial, e a visão de seus seguidores, Conan Doyle e Agatha Christie. Além disso, abordaremos outra vertente do romance policial, o romance Série Negra. Posteriormente apresentaremos a história desse gênero no Brasil.

\subsubsection{Dupin de Edgar Allan Poe: a invenção do romance de enigma}

Para entender o que levou Poe a invenção do gênero, devemos levar em consideração o contexto político-sócio-histórico da época que o influenciou. Na época em que Poe vivia, havia nos jornais populares de grande tiragem (que surgiram no século XIX na Europa), seções que trabalhavam com o chamado "fato diverso", ou seja, dramas e crimes raros e inexplicáveis que atraíam a atenção do grande público para a leitura regular. Público este, que moravam nas grandes cidades industriais, produtos da Revolução industrial. Tendo isto como base, os crimes das primeiras narrativas policiais de Poe aconteciam em ambientes urbanos (REIMÃO, 1983, p.11).

A polícia, em sua significação contemporânea do termo, surge a princípio na França, com o recrutamento de ex-condenados no início do século XIX, ou seja, pessoas que conhecem profundamente o mundo do crime. Tal situação, em que era leve o limite entre um contraventor e um ex-contraventor, não era muito aceita pela classe média da época. Em oposição a isso, as primeiras narrativas policiais de Poe eram de oposição a esse tipo de investigador, criando como personagem central de suas histórias, o detetive Chevalier Dupin, que não pertencia à polícia. Eis que surge naquele momento o protótipo do detetive moderno.

Outro ponto que influenciou Poe em suas criações na época foi o Positivismo, movimento filosófico que tinha como pressuposto a ideia de que os fenômenos são regidos por leis, tendo como consequência a ampliação da teoria da associação de ideias, em que estava em alta a visão de que a "mecânica mental obedece a certos princípios gerais e quem dominar estes princípios saberá usá-los em cada cadeia de ideias, de cada homem particular" (REIMÃO, 1983, p.13).

Além disso, o cidadão urbano da época, apoiado nas ideias positivistas, tinha uma nova visão do criminoso, a de um inimigo social, que podia prejudicar a sociedade como um todo. Essa figura criminosa passou a ser patologizada, pois ela apresenta um quadro clínico de doenças mentais, devido à degradação dos seus valores éticos e morais. A partir dessa visão, surgem nas narrativas policiais o termo "gênio do crime" em oposição ao "gênio da justiça" 
que seria o detetive (REIMÃO, 1983, p.15).

Levando em consideração o contexto descrito acima, na Inglaterra, França e EUA estavam sendo produzidas nos jornais as novelas de folhetins, baseadas em policias excondenados que utilizavam em suas investigações métodos empíricos. Conforme Reimão (1983), de forma contrária e totalmente inovadora, o americano Allan Poe lançou na Graham's Magazine, sua primeira narrativa policial, Assassinatos na Rua Morgue, fundando o gênero. De forma inovadora, o protagonista C. Auguste Dupin era um detetive moderno, que fazia suas investigações pautadas em inferências a respeito dos pensamentos que permeavam a mente dos envolvidos nos crimes, inferências estas que eram muito bem vistas pelo Positivismo. O detetive se apresentava como uma pessoa que tinha a investigação com um substituto ao ócio, propondo ao leitor, a princípio, a ideia de que a leitura é também uma forma de se afastar do ócio. A base das histórias era o crime que acontecia nas novas cidades industriais.

Esse modelo literário descrito aparece apenas nos contos: Assassinatos na Rua Morgue, O Mistério de Marte Roget e A Carta Roubada. Conforme Reimão (1983), a invenção do gênero policial é o resultado da nova proposta de Poe a respeito da literatura, onde ele combinava a ficção com raciocínio e inferências lógicas, deixando de lado a ideia de fantasia para ter algo mais palpável e real. Essa visão foi apresentada em seu texto Métodos de Composição, onde Poe levantou o método que deveria ser utilizado na criação de um texto literário. Levando para a narrativa policial, Reimão (1983) salienta dois pontos deste texto, sendo o primeiro a substituição do acaso e da intuição pelo rigor e precisão e o segundo é a forma de escrita da história. Para Poe, a história deveria ser escrita de trás para adiante, de forma que os incidentes se dirigiriam ao fim desejado, estabelecendo um rigor lógico, utilizado pelo autor no método de investigação do detetive Dupin das histórias, assim como na construção do texto.

As histórias de Dupin são narradas por um narrador anônimo, que é seu amigo, sendo apenas um mediador, estabelecendo um modelo de enunciação comum ao romance policial de enigma. O leitor tem poucas informações a respeito deste narrador e também do detetive, que é visto como uma máquina de raciocinar. Dupin faz suas inferências por meio de fatos vistos em jornais, relatos verbais, entre outros, construindo teorias a respeito dos fatos e até mesmo dos pensamentos dos outros personagens sem sair de sua casa. Conforme Reimão (1983, p. 21), isso é o resultado da ideia do "homem como uma máquina desmontável", que segue princípios universais que ao serem desvendados por alguém, possibilitará o entendimento dos 
pensamentos alheios (REIMÃO, 1983).

Um recurso muito interessante utilizado por Poe é a criação de suas histórias de ficção tendo como ponto de partida, histórias reais. Com isso, os leitores se deparam com fatos de acontecimentos reais, como o assassinato de Mary Cecília Rogers (relatado em O Mistério de Marie Roget), que são transportados para a ficção.

Uma das regras básicas do romance de enigma, é ser composto por duas histórias, a história do crime e a do inquérito, sendo que a primeira pode não estar diretamente presente no livro, ou seja, pode aparecer de forma indireta, por meio de relatos dos envolvidos no crime. Já a segunda, estará presente no decorrer da investigação, sendo o espaço em que os personagens atuam. Tal estrutura que não tem como foco o crime, mas sim o inquérito, construiu a narrativa policial clássica. Sendo assim, o detetive se tornava imune aos perigos no decorrer da investigação, pois os personagens da segunda história não agiam, apenas relatavam os fatos da ação passada. Isso reafirma a ideia do detetive como uma "máquina", que não morre. Diferente de Dupin, o narrador não é uma "máquina", por isso se surpreende com as deduções do detetive, estando no mesmo patamar do leitor, que se surpreende a cada fato desvendado (REIMÃO, 1983, p. 23).

Outro componente importante da construção narrativa de Edgar Allan Poe é o grande uso de superlativos, antíteses e hipérboles, que por sinal eram muito adequadas nas narrativas do século XIX. Além disso, jogos intertextuais estão presentes não apenas nos textos de Poe, mas em toda a evolução do romance policial.

\subsubsection{Sherlock Holmes de Conan Doyle}

O detetive Sherlock Holmes foi a criação literária de Conan Doyle (1859-1930) mais expressiva e famosa do romance de enigma, sendo levado inclusive para o cinema. Diferente de Poe, Doyle inovou ao dar importância central ao narrador da história, que no caso das histórias de Holmes era John Watson.

O narrador pode ser de três tipos: o narrador impessoal, vários narradores ou personagens-narradores. Dentro da classificação personagens-narradores, há os personagensnarradores fixos, os memorialistas ou historiógrafos dos detetives. A criação do narrador se deve ao fato da impossibilidade do detetive assumir essa função, pois ao fazer suas deduções e expô-las ao leitor, acabaria com o suspense da descoberta final, pois o leitor estaria andando 
lado a lado com o detetive na trama, sendo que é função dos narradores promoverem nos leitores sua admiração pelo detetive (REIMÃO, 1983).

Porém, Watson não era um simples narrador. Ele selecionava quais histórias iria relatar com base em três princípios: especificidade da matéria para valorizar o público leitor, narrativas que salientassem as qualidades do detetive e casos que fossem solucionados mediante provas lógicas. Sendo assim, Watson buscava, a princípio, saciar a sede de seus leitores com notícias inéditas e buscava especificidades na forma do tratamento da matéria, ou seja, a forma de abordá-la que era única de Holmes e que deveria ser admirada. Outro ponto importante é a forma de narração adotada por Watson que nem sempre coincidia com o que Holmes esperava. Watson atuava quando o enigma já havia sido resolvido, tentando entender o processo de investigação e, por fim, tentando esclarecê-lo ao leitor. Isso mostra que a visão de Watson sobre os fatos era parcial, pois ele sabia o mesmo que os outros personagens, assim como o leitor (REIMÃO, 1983).

Reimão (1983) acredita que o sucesso de Conan Doyle com a criação de Holmes se deve também a outros dois fatores, o primeiro é a personalidade de Sherlock Holmes, que além de ser uma "máquina dedutiva", também tinha personalidade própria, fazendo com que o leitor se aproximasse mais do detetive. O outro fator se refere a metodologia de investigação adotada por Holmes, que utiliza além de suas deduções intelectuais, procedimentos técnicos científicos na análise dos dados do crime como, por exemplo, de impressões digitais.

O uso do jogo intertextual permanece com Doyle, sendo uma "metalinguagem, uma auto-reflexão do gênero nascida na própria história deste” (REIMÃO, 1983, p.39). Tal uso continuou sendo feito posteriormente nos romances de enigma, podendo ser interpretado como algo fundamental por leitores assíduos, pois deram especificidade ao texto ou pode ser visto como algo estranho aos leitores não habituados com o gênero, isto é, tais digressões não terão sentido, porém, poderão servir de indicações para novas leituras (REIMÃO, 1983).

\subsubsection{Agatha Christie}

Os textos de Agatha Christie seguem uma linha mais "clássica" do romance de enigma, com base nos modelos de Edgar Allan Poe e Conan Doyle. Os detetives criados por ela foram Miss Jane Marple, Mrs. Ariadne Oliver, Superintendente Battle, o casal Tommy e Turppence Beresford, Mr. Parker Pyne, Mr. Quin, Mr. Satterthwaite e o mais famoso, o 
detetive belga com características francesas, Hercule Poirot, que só ficou atrás de Sherlock Holmes na história da narrativa policial.

Ao mesmo tempo em que Agatha Christie segue a tendência "clássica" do romance de enigma, conforme Reimão (1983), ela também produziu obras que romperam as regras consideradas clássicas (de Van Dine ${ }^{11}$ ), como por exemplo, a história em que o narrador é o criminoso, a que o crime é criado e executado por vários personagens, a peça que o público sabe de antemão quem é o assassino e outra onde todos os personagens principais morrem.

Em alguns dos textos no qual Poirot é protagonista, há a figura do capitão Hastings, que atua como narrador-personagem. Seu desejo sempre foi se tornar um detetive, porém, ele é lento em deduzir pistas e explicar os fatos, por isso, nos momentos que ele é ludibriado por pistas falsas, muitas vezes o leitor também se perde, pois é por ele que o leitor recebe as informações. Em contrapartida, há momentos que o leitor consegue perceber os enganos de Hastings e se adiantar no entendimento da trama.

Diferente de alguns outros detetives mencionados anteriormente, Poirot utiliza em suas investigações tanto o trabalho de dedução mental, como o trabalho empírico na busca de pistas, sendo que o primeiro é considerado mais decisivo em suas deduções. Outro ponto que difere as criações de Agatha Christie das de outros autores é que ela foi uma das autoras que salta do real, do campo do verossímil, para a esfera dos possíveis, ficando muito mais próxima da ficção, e faz isso de forma mais radical. Além disso, é importante salientar que Agatha Christie faz uso dos jogos intertextuais nas obras em que Poirot é o personagem principal (REIMÃO, 1983, p. 41).

\subsubsection{O Romance "Noir"}

Conforme relatado anteriormente, várias mudanças ocorreram no romance de enigma, porém a mais expressiva ocorre com a criação do romance negro, também conhecido por romance americano, que segundo alguns estudiosos foi criado por Dashiell Hammett (18941961), que teve seu ápice por meio da coleção "Série Noire", publicada na França em 1945 por Marcel Duhamell.

Vejamos o que diz Boileau-Narcejac:

11 Van Dine enunciou em 1928, vinte regras no artigo do American Magazine que eram consideradas básicas no gênero. 
Ora, se é emoção que se procura, a saber, a emoção brutal, aquela que precisamente paralisa o raciocínio, então se renuncia ao Romance Policial propriamente dito, em proveito de outra coisa que se chamará romance criminal ou romance 'noir'.

É aqui que a palavra "polar" (Em francês, termo popular para romance policial, com a conotação de vulgarização.) vem criar o equívoco. Claro, objetar-se-á que o "polar" mantém a investigação e quer somente corrigir por uma ação arrebatada a natureza demasiadamente cerebral do R. P. Mas, desde que se abandona o enigma exatamente construído para o quebra-cabeça ou, pior ainda, o imbróglio, desde que substitui, por conseguinte, o rigor pelo tateamento, não há mais detetive. Resta um empreiteiro da investigação que, em vez de progredir de maneira necessária rumo à verdade, só a encontra finalmente por acaso (BOILEAU-NARCEJAC, 1991, p. 5).

Essa mudança proposta pelo romance negro ocorre em um contexto de grande confusão política que surgiu após a Primeira Guerra Mundial. O início das publicações ocorrem às vésperas da II Guerra Mundial, e é escrito para um público diferenciado do romance de enigma, que buscam questionamentos da sociedade em que vivem. Segundo Vera Lúcia Follain de Figueiredo (1988, p. 22), a passagem do romance de enigma para o noir seria a passagem do pensamento para ação. Essa diferenciação pode ser vista no trecho abaixo, presente nos primeiros volumes da coleção:

O leitor desprevenido que se acautele: os volumes da Série Noire não podem, sem perigo, estar em todas as mãos. O amante de enigma à Sherlock Holmes aí não encontrará nada a seu gosto. O otimismo sistemático tampouco. A imoralidade, admitida em geral nesse gênero de obras, unicamente para contrabalançar a moralidade convencional, aí se encontra bem como os belos sentimentos, ou a amoralidade simplesmente. O espírito é raramente conformista. Aí vemos policiais mais corrompidos do que os malfeitores que perseguem. O detetive simpático não resolve sempre o mistério. Algumas vezes nem há mistério. E até mesmo, outras vezes, nem detetive. (DUHAMELL apud REIMÃO, 1983, p. 52).

Conforme Reimão (1983) podemos dizer que o romance negro é a inversão do romance de enigma, com características inovadoras e não apenas inovadoras por oposição, mas, que traz em seu enredo características vistas socialmente como negativas. No romance negro há a destruição da estrutura de dupla história, não apresentando mais uma narrativa em forma de memória e sim construída no presente, coincidindo com a ação. Isso ocorre porque muitas vezes a história é narrada pelo próprio detetive (regra do romance negro), portanto, a ideia de imunidade física do detetive se perde e o leitor passa a estar diretamente ligado às descobertas com o detetive. Devido a esse envolvimento do detetive com a trama, ações são geradas e constituem parte da história (detetive da ação). Os traços psicológicos de personalidade dos personagens não são relatados nas histórias e, para Reimão (1983), isso acontece devido à oposição existente entre o romance negro e o romance psicológico que predominou após a I Guerra Mundial, tendo como principais representantes André Gide e 


\section{Marcel Proust (REIMÃO, 1983).}

As histórias trazem resultados de investigações que não são mais inquestionáveis devido ao ponto de vista do investigador. Por isso, os resultados são suscetíveis a dúvidas, onde não há mais uma verdade final indiscutível, tendo um protagonista frágil, diferente dos detetives Holmes e Dupin. O detetive está no mesmo patamar ético-moral dos outros personagens da história e do leitor, que se envolve emocionalmente. Além disso, opta-se pela utilização da linguagem coloquial em detrimento da linguagem culta, com o uso de palavras de baixo calão, e tem o humor como um ingrediente importantíssimo (REIMÃO, 1983).

Um fator que marca os textos de Hammett é a crítica ético-político-social, "utilizando o mundo do crime como uma metáfora da sociedade em geral” (REIMÃO, 1983, p.61). Para fazer isso, o protagonista da história dialoga com o leitor, visando fazê-lo enxergar o mundo e questionar criticamente o espaço em que vive.

Para exemplificar tais características, tomemos como exemplo o detetive Sam Spade, criado por Dashiell Hammett e o detetive Philip Marlowe criado por Raymond Chandler (1888-1959), seguidor mais expressivo de Hammett. Sam Spade é um detetive que trabalha para sobreviver, é um empregado assalariado que vive envolvido com mulheres em relacionamentos sem romantismo e com bebida, inclusive quando está trabalhando.

Assim como ocorre com Sam Spade, inicialmente Chandler cria um detetive sem nome e depois dá vida a Marlowe, que via de regra, sempre é o narrador de suas histórias. Marlowe tem propositalmente um vocabulário com erros gramaticais, carregado de gírias e palavras rudes. Ele é um detetive profissional, que trabalha por dinheiro. Muitas vezes se envolve emocionalmente com os casos que investiga e nunca bebe quando trabalha. Marlowe mostra claramente a fragilidade de seu trabalho ao apresentar resultados de investigações vagos e imprecisos e por nunca fazer deduções sem contrastá-las com a realidade, não faz inferências acerca do caráter das pessoas. Vemos que ambos são bem humanizados, se mostram detetives com sentimentos.

\subsubsection{O romance policial brasileiro}

Assim como o romance de Edgar Allan Poe, o romance policial brasileiro nasceu em folhetins, em rodapés de jornal. O interessante é que se passaram setenta e nove anos desde a 
primeira publicação de Poe, cabendo aqui, a opinião de Medeiros e Albuquerque (1979, p.206) a este respeito: "E nós, já nessa época, ainda estávamos naquele tempo".

Veja alguns trechos da divulgação feita pelo jornal A folha, jornal de Medeiros e Albuquerque (apud Medeiros e Albuquerque, 1979, p.205), no dia 20 de março de 1920 do início da publicação dos romances:

Começamos hoje a publicação do romance $O$ Mistério, escrito por Coelho Netto, Afrânio Peixoto \& ${ }^{12}$, Viriato Correia.

Seria atualmente impossível reunir três nomes de prosadores que superassem em mérito os autores do folhetim, cuja publicação hoje iniciamos.

O que há de interessante nele, além do raro valor literário dos três grandes nomes que o vão escrever, é o fato da surpresa contínua em que viverão os leitores. E a surpresa aqui é tanto mais infalível, quanto os próprios autores a terão. Nenhum deles sabem o que os outros vão fazer. É lendo o que o seu colaborador da véspera produziu, que cada um decide o que tem de escrever.

E tudo será feito não com o descuidado estilo dos fabricantes de rodapés sem arte, mas com a superioridade de três dos maiores nomes de nossa literatura (ALBUQUERQUE, 1979, p.205).

A partir da nota, vemos que a ideia de escrever $O$ Mistério foi de Medeiros e Albuquerque, que inclusive escreveu o primeiro folhetim com o pseudônimo \&. O Mistério foi escrito em quarenta e sete capítulos no folhetim, tornando-se livro no mesmo ano. $\mathrm{O}$ sucesso foi tanto, que em 1928 o livro obteve a venda de dez mil exemplares.

O Major Mello Bandeira é o detetive da história, com um estilo parecido com o de Sherlock Holmes, uma máquina de raciocinar, porém, em certo momento, Bandeira tem uma atitude carinhosa com uma das personagens da trama, perdendo assim, sua caracterização. $\mathrm{O}$ assassino da história, Pedro Albergaria, é utilizado pelos autores com o intuito de direcionar críticas à polícia. Porém críticas à polícia, ao sistema judiciário e ao detetive não são as únicas, pois, conforme dito por Reimão (2005), a própria narrativa ironizava a literatura policial de enigma clássica, como se auto-ironiza, utilizando seus recursos de forma exagerada. Cabe ressaltar, que a falência do personagem Bandeira enquanto detetive, não se propagou nas posteriores obras de romance policial no Brasil, sendo que, caso houvesse a presença de traços pessoais, estes apareceram como justaposições, agregações, não alterando o desempenho dos detetives (REIMÃO, 2005).

Conforme Reimão (2005, p.14), essa proposta de parceria na escrita do romance $O$ Mistério, em que era impossível um planejamento prévio, muito menos a realização de uma 
revisão, em que um autor dava continuidade ao capítulo do autor anterior, conferia a narrativa um caráter lúdico, um aspecto de "irresponsabilidade, de brinquedo".

Depois da publicação nos jornais, Medeiros e Albuquerque publicou mais dois livros de contos policiais, O assassinato do General em 1926 e Se eu fosse Sherlock Holmes em 1932. Já os outros autores do romance $O$ Mistério, deixaram de publicar o gênero. Depois desses trabalhos, durante um bom período de tempo, cessaram as publicações, afinal, havia uma ideia preconcebida contra o gênero (MEDEIROS E ALBUQUERQUE, 1979).

Na década de 30 surgiu Jerônimo Monteiro, que por trás do pseudônimo Ronnie Wells criou o detetive Dick Peter. Ele foi o primeiro a utilizar um pseudônimo. A princípio, Dick Peter foi criado para uma série radiofônica em São Paulo e três anos depois estava nos livros, em dez volumes. Segundo Medeiros e Albuquerque (1979, p. 210), "suas histórias não eram apenas policiais e sim uma mistura de mistério, ficção científica e até mesmo de detecção policial ". Não se pode dizer ao certo quantas obras foram publicadas por Jerônimo Monteiro, mas ele deve ser reconhecido por ser o primeiro a criar o detetive que teve mais de uma aventura. A título de curiosidade, Dick Peter publicou na Editora Edições e Publicações do Brasil e na Livraria Martins Editora. Dentre as obras, há $O$ fantasma da $5^{\circ}$ avenida, Dragão O estrangulador, $O$ crime do $9^{\circ}$ andar, Clube da morte, O enigma do automóvel da Prata, entre outras.

Conforme dito anteriormente, a literatura policial brasileira costuma usar de modelo o detetive clássico, que utiliza a mente para desvendar os mistérios. Porém, nos detendo às exceções, temos o protagonista de Quem matou Pacífico?, Tonico Arzão. Criado por Maria Alice Barroso, ele era um delegado que resolvia os mistérios com a ajuda de seu lado místico e supersticioso, reconstituindo o momento do crime, onde o assassino aparecia em forma de reencarnação. Além disso, ele tinha características opostas aos detetives do romance de enigma clássico.

Com essa abordagem de cada grupo de narrativas policiais, podemos perceber as mudanças que foram acontecendo com o decorrer do tempo na escrita do gênero, porém é notável que a estrutura básica do romance de enigma não é alterada, pois ela continua agindo na esfera do raciocínio. Por meio desse capítulo podemos perceber as mudanças na caracterização do detetive que, a princípio era visto como uma máquina de raciocinar, sem personalidade própria, tendo como exemplo Dupin. Posteriormente, surgem os detetives mais humanizados, próximos do real, com personalidades próprias, como é o caso de Holmes e Poirot. 
Os métodos de investigação também sofreram mudanças. A princípio, as investigações eram feitas apenas no âmbito do intelecto, posteriormente, procedimentos técnicos científicos passaram a ser utilizados e a criação de elementos ficcionais sofisticadíssimos para incrementar a trama surge rompendo com a verossimilhança, sendo cada vez mais difícil para o leitor desvendar o crime, assim como era a proposta do romance de enigma clássico. Reimão (1983, p.76) acredita que isso se deve a importância que o narrador adquire no romance, dificultando o acompanhamento das deduções do detetive por parte do leitor. Mesmo com todas essas mudanças, a ideia do romance como "quebra-cabeças" não se perde.

Já no romance americano, há a inversão das características básicas do detetive, a narrativa coincide com a ação, a ideia de resultado de investigação inquestionável se perde dando lugar ao erro humano e surge a intenção de criar um leitor que questione, por meio da história, o contexto social em que está inserido e se posicione.

Refletindo a respeito de tudo que foi apresentado e sobre o que Boileau-Narcejac (1991) diz sobre o romance "noir", caracterizando-o como "a decomposição do romance policial", acreditamos que o romance policial (romance de enigma) e o romance negro são produções literárias distintas, destinados a públicos distintos, que optam por ler o que lhes é mais compatível, o que lhes agradam. Por isso, convivem muito bem juntos. Um se destina a um público interessado no raciocínio, no que a mente proporciona, e o outro, em uma possibilidade de se obter um novo olhar acerca da realidade e do mundo.

Haja vista que o romance negro possui características que foram herdadas do romance policial, podemos dizer que este serviu de modelo, nem que seja um modelo de oposição. Essa diferença marcante do romance policial para os outros pode ser pensada tendo como base a frase de Boileau-Narcejac (1991, p.8) "O romance policial é precisamente um gênero literário, e um gênero cujos traços são tão fortemente marcados que não evoluiu, desde Edgar Poe, mas simplesmente desenvolveu as virtualidades que trazia em sua natureza". Vimos também que a literatura policial brasileira costuma usar como modelo o detetive clássico, que utiliza os recursos mentais para desvendar os mistérios.

Para conhecermos melhor a obra literária utilizada e analisada nesse trabalho, iremos apresentar no capítulo seguinte a história do surgimento e da proposta da Série Vaga-Lume da qual da obra faz parte, assim como, relatar a história da autora Lúcia Machado de Almeida. Posteriormente contaremos brevemente o enredo da obra e detalharemos alguns conteúdos conceituais que estão presentes na obra e que também podem ser obordados em sala de aula tendo o romance como recurso. Porém, não é o foco desse trabalho abordar tais conteúdos nas 
propostas didáticas, portanto, esses conteúdos foram apresentados com o intuito de possibilitar uma melhor compreensão do professor sobre os conteúdos abordados e suas possibilidades, cabendo a ele um trabalho mais profundo nesse sentido. No final do capítulo são estabelecidas as possíveis relações entre o trabalho do cientista com a investigação do detetive, apresentando as interfaces entre essas duas figuras e fazendo um debate sobre as possibilidades do uso da obra na realização de comparações análogas entre o fazer científico e o desvendar de um mistério. 


\section{CAPÍTULO 3: O CASO DA BORBOLETA ATÍRIA}

Sabendo que as Ciências da Natureza fazem parte do currículo do Ensino Fundamental e que tal área do conhecimento engloba uma grande quantidade de assuntos a serem abordados, principalmente aqueles de alto nível de interesse e curiosidade dos estudantes, o presente projeto foi pensado e elaborado, com o objetivo de trabalhar alguns destes por meio da literatura, e para isso apresentaremos a análise da obra literária infanto-juvenil $O$ caso da borboleta Atíria de Lúcia Machado de Almeida (1991) onde buscamos averiguar seu discurso, verificando se nela há a abordagem de temas científicos, como essa abordagem é feita e entender como é realizada a investigação dos acontecimentos que permeiam a história da obra para propor atividades pautadas nesse viés investigativo para o Ensino de Ciências. A partir disso, entender a visão e o intuito da autora e apresentar uma reflexão sobre as possibilidades de utilização de tais obras literárias no Ensino de Ciências, com ênfase na investigação científica e nos diferentes métodos científicos utilizados. A proposta levantada é a de que o uso da obra em sala de aula não seja encarado simplesmente como "uma leitura por leitura", e sim que proporcione prazer e um aprendizado diferenciado.

Alguns pontos foram determinantes na escolha da obra, dentre eles o fato desta e de outras que compõe a Série Vaga-Lume da editora Ática estarem presentes nas salas de aula e bibliotecas escolares, desde a década de oitenta e fazerem parte do repertório de leitura de muitos alunos atualmente. Mesmo que tais livros não tenham sido concebidos para ensinar Ciências, eles são repletos de conteúdos que permeiam várias áreas de conhecimento, possibilitando trabalhos interdisciplinares por meio da literatura. Pensando nisso e sabendo que tal uso muitas vezes não é voltado para o Ensino de Ciências, haja vista que poucos são os trabalhos na área do Ensino de Ciências sobre a Literatura Infantil e Infanto-juvenil, seu uso necessita ser repensado e explorado em sala de aula. Por meio de pesquisa ${ }^{13}$, constatamos que tal coleção ainda está sendo adotada como livro paradidático nas escolas até o presente

13 Com o intuito de argumentar a favor do uso da obra $O$ caso da borboleta Atíria fizemos contato com a editora Ática para averiguar se a obra está sendo utilizada até os dias de hoje nas escolas como livro paradidático, porém, por meio do contato via e-mail, só foi possível constatar que a obra é editada e vendida atualmente pela editora. Para exemplificar esse uso atualmente podemos ver que o livro consta nas listas de materiais de 2011on-line dos Colégios "Ressurreição Vita et pax", "Stella Maris" e "Antônio Vieira" disponíveis

em: <http://www.aper.org.br/ribeirao/imagens/downloads/LISTA\%20MATERIAL\%20ESCOLAR\%206\%C2\%B A\%20ANO\%202011.pdf , http://www.fea.br/Anglo/calendario/lista\%20material_fund_\%20-2011.pdf e http://www.colegioantoniovieira.com.br/userfiles/LISTA_MATERIAIS_4_SERIE_EF_2011(1).pdf> Acessado em 16 de fev 2011. 
momento e pelo contato com a editora via e-mail (EDITORA ÁTICA, 2011) fomos informados que a editora edita e vende a obra. Além disso, essa literatura foi escolhida por possuir qualidade, tiragem grande e por trabalhar conteúdos científicos com uma linguagem bem próxima da utilizada pelos alunos.

\subsection{A SÉRIE VAGA-LUME}

O início da publicação da série Vaga-Lume pela Editora Ática foi dia 03 de junho de 1965. Sua origem se deu a partir do curso Madureza Santa Inês voltado para jovens e adultos, e surgiu com a intenção de divulgar as apostilas produzidas pelo curso. Portanto, no princípio os primeiros livros tinham cunho didático, sendo que as publicações das obras de literatura só começaram a serem executadas em 1970 (BORELLI, 1996, p. 97).

A série Bom Livro, também da editora Ática, abriu caminho para o setor dos paradidáticos nas áreas de Português e de Literatura, trazendo publicações de clássicos da literatura brasileira e portuguesa. Possuía um suplemento literário ${ }^{14}$, que ligava a série à escola e trazia exemplares destinados aos professores com questões resolvidas, como recurso de apoio. Ainda hoje,

\footnotetext{
"a série Bom Livro ainda continua a ser publicada, e é bastante requisitada pelos alunos do Ensino Médio e do Ensino Superior, devido à facilidade na leitura, além de possuir textos confiáveis e uma comercialização a preço mais baixo do que nas editoras concorrentes" (BORELLI, 1996, p.106).
}

A série Vaga-Lume acompanhou a tendência da época e foi lançada com fichas de leitura (ANEXO A: ficha do livro $O$ caso da borboleta Atíria), de modo a ser utilizada em sala de aula, seguindo as determinações estabelecidas pelo $\mathrm{MEC}^{15}$ na década de 70 . Tal fato foi uma inovação da Editora Ática que possibilitou a criação de um novo modo de trabalhar a literatura na escola. A série Vaga-Lume surgiu para atender as necessidades de livros paradidáticos para o primeiro grau (BORELLI, 1996, p. 107) e, diferente da série Bom Livro, é composta por obras de autores que não pertencem ao cânone da literatura brasileira, possuindo narrativas simples, enfáticas na "ação", palavra a partir da qual se estruturam as propostas literárias (BORELLI, 1996, p.115), podendo ser um dos motivos de tanto sucesso junto aos jovens.

Por volta do final do ano de 1972, José Adolfo Granville Ponce, editor da coleção

14 Disponível em www.atica.com.br Acessado em 15 de março de 2010.

15 Ministério da Educação (http://www.mec.gov.br/) 
Ensaios, propôs a criação de uma coleção dirigida para o publico juvenil, com a direção de Jiro Takahashi, com a visão de que o jovem não é um adulto em miniatura e que por isso, os livros teriam suas narrativas adequadas a essa faixa etária, dando surgimento à Vaga-Lume. Conforme Mendonça (2007), se analisarmos o contexto da literatura juvenil dos anos 70, veremos que essa foi uma época em que o governo aumentou o número e o ritmo de lançamentos dos novos títulos escritos para crianças e jovens, gerando um incentivo à produção de obras produzidas por autores brasileiros. Também nesse período foram incluídos nos livros voltados para crianças, suplementos com "instruções e sugestões didáticas; fichas de leitura, questionários, roteiros de compreensão do texto" que "marcam o destino escolar de grande parte dos livros infanto-juvenis a partir de então lançados" (LAJOLO e ZILBERMAN, 1985, apud MENDONÇA, 2007, p. 87). O diferencial da Editora Ática foi o fato de inovar ao criar os suplementos com base em informações dela própria.

Na década de setenta, sob a perspectiva tecnicista, a Escola passou a ser profissionalizante e houve a proliferação das escolas particulares, tendo como consequência uma baixa qualidade no ensino que contribuiu para o desenvolvimento de textos voltados para as massas. O ensino da língua passou a ser feito sob a perspectiva da comunicação e da expressão, tornando textos literários nacionais obrigatórios para o ensino da Língua Portuguesa. Com base em todos esses aspectos, percebemos que a série Vaga-Lume acompanhou a tendência da época, fazendo uma ponte entre a Escola e a literatura (MENDONÇA, 2007).

Conforme Mendonça (2007), a partir da leitura dos livros de literatura infanto-juvenil da coleção, as diversas tendências discursivas dessa época, como o utilitarismo às avessas no questionamento dos conteúdos burgueses, a valorização da figura infantil e de seus questionamentos, entre outros, nos dão uma alusão de como caminhavam os pensamentos da época e em que medida eles influenciaram a literatura.

Os livros contemplam diversos estilos: aventura, policial, fantasia, humor, romance, protagonizados por personagens envolvidos em mistérios e aventuras. A primeira obra da série foi A ilha perdida de Maria José Dupré, em 1973. Essa foi uma terceira edição da obra, que teve a primeira datada em 1944 e que já se tratava de um sucesso quando foi levada para a série. Essa obra trazia consigo elementos característicos da narrativa da época, assim como outras que compuseram os primeiros títulos da Série Vaga-lume, como Éramos Seis (1943), que rendeu à autora Maria Jose Dupré grande sucesso, além do prêmio Raul Pompéia da Academia Brasileira de Letras em 1944. 
O segundo livro publicado na série Vaga-lume foi Cabra das Rocas, de Homero Homem. Assim como o livro A ilha perdida, ele também já havia sido publicado anteriormente com o titulo $O$ povo das rocas em 1960, porém, não era direcionado para o público jovem. Já em 1966 foi republicada com o título atual e indicada para os jovens e em 1973, a obra surge na coleção Vaga-lume com indicação a estudantes da $4^{\mathrm{a}}$ e $5^{\mathrm{a}}$ série (COELHO, 1983, p.345). Do mesmo autor, o livro Menino de asas foi editado pela primeira vez em 1969 e posteriormente em 1973 e foi editado pela segunda vez por meio da Editora Gernasa. Em 1975 voltou a ser editada pela Novacultura, passando a compor a série Vagalume apenas em 1978. Em 1988, a obra chegou a vender mais do que o dobro das vendas de Cabra das rocas e esteve na lista de honra do Premio Hans Christian Andersen comemorativa do Ano Internacional da Criança, em 1979.

A obra $O$ caso da borboleta Atíria de Lucia Machado de Almeida havia sido publicada pela primeira vez em 1951 e teve sua publicação pela Série Vaga-lume em 1976, trazendo grande sucesso à autora. Em sua primeira edição, a obra era intitulada $O$ caso de Atíria, a borboleta e para ser incluída na série sofreu alterações no título e em outros pontos. Em uma reportagem de Cassiano Elek Machado (2012) do jornal Folha de São Paulo, intitulada Coleção Vaga-Lume comemora 40 anos com edição digital e versões no cinema, o atual editor da Série Vaga-lume ressalta a importância dos designers e ilustradores, "que criaram uma identidade marcante para a coleção". No caso da obra O Caso da Borboleta Atíria o ilustrador Milton Rodrigues passou um tempo internado no Museu de Zoologia para dar qualidade às suas ilustrações e disse "Não tínhamos internet e a melhor maneira de saber a forma de um 'Dynastes hercules' era ir ao museu...".

Da mesma autora, a obra $O$ escaravelho do diabo foi um dos maiores sucessos da série Vaga-lume, que teve sua segunda edição em 1974, sendo publicada pela primeira vez na revista $O$ Cruzeiro (MENDONÇA, 2007). Também de Lucia Machado de Almeida, a obra As aventuras de Xisto com primeira publicação em 1957 e que aparece na série como terceira edição em 1973, sofreu alterações. A mais significativa foi realizada na passagem da segunda para a terceira edição, quando houve "a ampliação da matéria ligada ao conhecimento cientifico, a presença do mágico ou do maravilhoso e também a nova consciência de linguagem" (COELHO,1983, p.479).

Diversos são os livros da série Vaga-Lume que povoaram e povoam o imaginário dos jovens. A maior parte deles foram escritos nos anos 70, mas tiveram seu ápice na década de 80, época em que passamos a conhecer os excelentes livros de autores como Marcos Rey, 
Lúcia Machado de Almeida, Maria José Dupré, José Maviael Monteiro, Lygia Bojunga Nunes, Marina Colasanti, Bartolomeu Campos Queirós, Sérgio Caparelli, Ana Maria Machado, Ruth Rocha, João Carlos Marinho, etc.

As obras da série Vaga-Lume são indicadas para a classe infanto-juvenil e para todos aqueles que gostam de se deliciar com grandes aventuras. É difícil encontrar alguém que viveu sua infância ou pré-adolescência nos anos 80 e não leu uma obra da série. Dentre as mais de 90 histórias, alguma marcou e/ou ainda marca a vida de diversas pessoas com suas histórias fantásticas, seja por opção ou por obrigação de leitura escolar, mas que realmente geram prazer com suas histórias magníficas. Atualmente Machado (2012) nos conta em sua reportagem que a Série Vaga-Lume vai passar a lançar em 2013 novas linhas visuais com versões digitais das obras e no final deste mesmo ano começarão as filmagens de $O$ Mistério do Cinco Estrelas, de Marcos Rey.

\subsection{LÚCIA MACHADO DE ALMEIDA}

Lúcia Machado de Almeida colaborou para a série Vaga-Lume com obras de sucesso, principalmente entre os jovens dos anos 80. Suas obras são editadas até os dias de hoje e podem ser consultadas no anexo B juntamente com as obras de outros autores. A capa da obra estudada nessa pesquisa, $O$ Caso da Borboleta Atíria ${ }^{16}$ e a contracapa contendo a imagem das capas das outras obras podem ser visualizadas no anexo C e D.

A escritora Lúcia Machado de Almeida nasceu na Fazenda Nova Granja, no município de Santa Luzia em Minas Gerais no ano de 1910 e morreu em abril de 2005 aos 94 anos de idade. Ainda era criança, mudou-se para Belo Horizonte, onde realizou o curso primário e o secundário no Colégio de religiosas dominicanas Santa Maria. Ela também estudou inglês, francês, história da arte e da literatura, piano e canto. Lúcia é irmã dos escritores Paulo Machado, Aníbal Machado e Carolina Machado já falecidos. Pertenceu a uma família de intelectuais e foi casada com Antônio Joaquim de Almeida, irmão do poeta Guilherme de Almeida. Tornou-se jornalista profissional, tendo se iniciado nessa carreira quando

16 A obra foi publicada em braile tornando-a acessível para portadores de deficiência visual. Houve uma publicação pela Fundação Dorina Nowill para Cegos em 2004, disponível em [http://www.fundacaodorina.org.br/]. No site da Secretaria Municipal de Cultura do Estado de São Paulo [http://www.prefeitura.sp.gov.br/cidade/secretarias/cultura/bibliotecas/acervos_especiais/braile/index.php?p=23] é possível localizar as bibliotecas de São Paulo em que há a obra disponível. Acessado em 16/05/2011. 
adolescente (ALMEIDA, 1991, p. 3).

Seu primeiro trabalho literário foi realizado quando ela ainda era bem jovem, com apenas quatorze anos de idade, o poema Desencanto que foi publicado no Estado de Minas Gerais. Já seu primeiro livro No Fundo do Mar foi publicado alguns anos depois. Com essas publicações, ela ganhou diversos prêmios de destaque na literatura infanto-juvenil. Dentre os vários prêmios que conquistou, destacam-se: Medalha de Ouro da Bienal do Livro em São Paulo; Prêmio Othon Bezerra de Mello da Academia Mineira de Letras; além da condecoração Stella delia Solidarietá (medalha de mérito cultural do Governo Italiano) e de Chevalier des Arts et des Lettres, do Governo Francês.

\subsection{O CASO DA BORBOLETA ATÍRIA - HISTÓRIA DA OBRA}

O livro $O$ caso da Borboleta Atíria conta a história de uma borboleta órfã que é criada por uma jitiranabóia, a Dona Jitirana. Devido a um defeito em suas asinhas, ela não pode voar longas distâncias e por isso para realizar suas revoadas, precisa da colaboração de diversos insetos da floresta em que vive. O bosque onde vive Atíria é reinado pelo príncipe Grilo que já no início da história se vê frente ao desafio de descobrir quem assassinou sua noiva, chamada Helicônia. Para desvendar esse mistério, o príncipe conta com a ajuda do detetive Papilio, seu assistente Caligo e da borboleta Atíria na investigação do caso. No decorrer da história o príncipe passa a ter contato com uma borboleta chamada Vanessa que também é assassinada de forma misteriosa, se tornando o tema das conversas da população da mata. $\mathrm{O}$ grandioso mistério sobre o culpado norteia todo o desenrolar da história que é pautada na investigação do crime. A partir do momento que Atíria conhece o príncipe Grilo sua vida também passa a correr perigo, pois o príncipe era o alvo principal dos assassinos, porém, corajosamente a borboletinha vai enfrentar alguns inimigos como o Esqueleto-Vivo e passar por situações de perigo como suportar a câmara de tortura.

$\mathrm{Na}$ história da borboleta Atíria, a autora segue a tendência da década de 40, com o uso da zoomorfização dos personagens, aproximando a narrativa do público infantil. Conforme Mendonça (2007), essa obra tende a ser permeada por dois gêneros: o policial e o maravilhoso. O romance segue as regras do romance policial, em que há um crime e consequentemente uma investigação por parte do detetive. Já o tom maravilhoso utilizado no enredo da obra pode ser visto na realização do casamento entre animais diferentes, uma borboleta com um grilo. O maravilhoso também pode ser visto até mesmo na fala dos 
personagens, que são animais de diversas espécies que se comunicam por meio de diferentes linguagens (em borboletano, maribondês, mosquitano, besourês, sabiano, a língua mãe insetês, etc.) Conforme Mendonça (2007), a fragilidade da borboletinha Atíria devido a um defeito em suas asas, representa a criança em sua fragilidade, além de apresentar no enredo da história, ensinamentos de moral e atitude.

\subsection{CONTEÚDOS CONCEITUAIS CIENTÍFICOS DA OBRA}

Um ponto fundamental do livro e que é intuito desse trabalho apresentar, são suas possibilidades didáticas, pois nele está presente, além do caráter policial e fantástico, o mundo da ciência. Tais conteúdos, que são em sua maioria de cunho biológico, possibilitam ao leitor a apreensão de termos científicos e de informações diversas. Nesse tópico serão apresentados alguns conteúdos presentes no livro que podem ser trabalhados em sala de aula por meio do currículo, porém, cabe ressaltar que esse não é o foco dessa pesquisa, portanto, eles serão apresentados nesse tópico para que o livro possa também ser usado como um recurso a mais no tratamento desses conteúdos. Temos no livro a abordagem da diversidade de fauna e flora da floresta; fatores abióticos necessários á vida animal; termos científicos; características de comportamento, de alimentação, de habitat, de aparência, fases de vida dos seres vivos, etc.

O trecho a seguir mostra como acontece a metamorfose de uma borboleta, apresentando assim, características de comportamento e as fases dessa transformação:

Num bosque cheio de passarinhos e flores, aparecera certa vez uma pequenina e silenciosa crisálida, colada ao tronco de uma árvore. Uma velha Jitiranabóia examinava-a admirada, pensando nas coisas extraordinárias que estavam acontecendo com ela... Em toda parte as mães borboletas gostavam de vigiar as crisálidas, esperando a hora em que se completasse o fenômeno maravilhoso da metamorfose e as filhinhas-borboletas saíssem dos invólucros (ALMEIDA, 1991, p. $5)$.

Podemos ver também no trecho a seguir, como a autora apresenta mais características comportamentais da borboleta:

Era linda, e suas asas amarelas e pretas estavam como molhadas... Lembrava-se vagamente de seu estado de larva, quando se arrastava pelo chão e só sabia comer folhas e dormir. Depois do sono de dois meses... o esquecimento na crisálida... Até que um ímpeto de vida a fez tomas conhecimento real de sua personalidade (ALMEIDA, 1991, p. 5).

A diversidade da fauna e da flora na floresta onde vive Atíria é bem grande e podem 
ser debatidos temas como espécie, população, comunidade, ecossistema, esquema taxonômico (domínios, reinos, filos, classes, ordem, família, gênero e espécie) interações entre as espécies, entre outros temas presentes no currículo escolar. Alguns exemplos de fauna são as jitiranaboias, as borboletas, os besouros, os louva-a-deus, as cigarras, os grilos, os marimbondos, os gafanhotos, as corujas, as aranhas, os pássaros, os arlequins da mata, as joaninhas, as abelhas, as formigas, as taturanas, as lacraias, entre outras. No trecho a seguir, há alguns exemplos de fauna:

O homem abaixou-se e segurou a sacola de filó, procurando agarrar a borboleta... Nesse mesmo instant, veil zumbindo um marimbondo, que pousou na mão do entomologista. Ao percebê-lo, o homem... largou instintivamente o saco, que caiu no chão. Aproveitando do feliz imprevisto, Atíria saiu voando com tanta força... e pousou na primeira árvore alta que encontrou... Logo depois chegou um mosquito acompanhado de duas borboletas, que pousaram na mesma árvore em que estava Atíria (ALMEIDA, 1991, p.27).

Quanto à diversidade da flora, muitas são as belíssimas árvores que compõe a floresta, como o pé de Jacarandá onde vive Atíria, o milharal onde Atíria se perdeu e o pé de framboesa que gerava as frutinhas que a borboletinha tanto gostava.

A autora se preocupou em fazer uma pesquisa científica proporcionando ao leitor o contato com termos científicos, apresentando o nome e as características de diversas espécies de animais e plantas. Dentre os muitos citados está o famosíssimo detetive Papílio, cujo nome científico é Papílio anchisiades capys, pertencente á família papilonidae. O livro também relata que a borboleta Papílio é comum nos campos, prados e jardins do Brasil e que sua lagarta vive nas laranjeiras, trazendo outras duas informações importantes, o habitat e uma das fases de desenvolvimento da borboleta, a lagarta. Há também a borboleta chamada Bômbix, sobre a qual a autora relata:

\footnotetext{
Uma delas era branca, pequenina, toda peluda e chamava-se Bômbix (as atuais bômbix não voam, pois perderam essa faculdade em consequência do cativeiro a elas imposto pelos sericultores. Conhecida cientificamente por Bombyx mori)... - Sou tão importante, exclamou Bômbix, toda cheia de si. Não sei se vocês sabem que meu casulo produz fios com que se faz a seda... Pois é isso, meus caros... Infelizmente nem todos podem ser úteis como eu (ALMEIDA, 1991, p. 27).
}

Outro exemplo é o do vilão Esqueleto-Vivo, que segundo a autora, é um esqueleto de inseto desprovido de olhos e de asas, que possui filamentos nervosos de alta sensibilidade pressentindo tudo em sua volta. Ele habita grutas sombrias e pertence à família dos grilos (ALMEIDA, 1991, p. 11 e 77).

Dentre as histórias contadas sobre as interações entre as espécies, a autora Lúcia 
Machado de Almeida (1991, p.9) relata o mimetismo utilizado pelo Senhor Louva-a-deus para se proteger de predadores. No decorrer do texto, o personagem do louva-a-deus conta como funciona esse mecanismo ao dizer:

-Como vê, Senhorita Atíria, divirto-me com meu mimetismo. Quando quero passar despercebido, pouso nalgum alho de árvore e fico misturado nas folhas como se fosse uma delas... E, assim disfarçado, ouço muito segredo interessante e protejo-me contra os inimigos...(ALMEIDA, 1991, p. 9).

O mesmo acontece com a borboleta Caligo, que se utiliza do artifício de se parecer com uma coruja para enganar os investigadores, suas presas e toda a população da floresta. Tal fato pode ser visto no trecho:

A natureza colocara na parte detrás das asas de Caligo dois grandes círculos negros numa posição tal que faziam lembrar um par de olhos arregalados. $\mathrm{O}$ corpo comprido da borboleta assemelhava-se ao nariz das corujas e a cor, o tamanho e a forma de suas asas, quando vistos de baixo para cima, pareciam a cabeça daquela agourenta ave noturna. A ilusão era perfeita!.

Todas as borboletas do gênero Caligo possuem essa particularidade, o que o leitor poderá verificar examinando-as pelas costas e virando-as de cabeça para baixo (ALMEIDA, 1991, p. 66).

O debate desses casos poderá servir de exemplo para o ensino de conceitos de mimetismo, antes mesmo de ele ser inserido, possibilitando ao leitor uma abordagem do assunto de forma diferenciada, deixando mais claro ao leitor as vantagens e a importância desse recurso para os animais da natureza, como é também o caso de algumas borboletas que são parecidas com abelhas na cor e na forma. Com isso, as borboletas se aproveitavam para entrarem na colmeia e matarem as larvas, podendo assim, roubar o mel dos alvéolos (ALMEIDA, 1991, p. 55).

Olhando para o lugar de onde partiam os sons, Papílio, sem ser visto, descobriu duas grandes abelhas que vinham conversando. Seriam abelhas mesmo? Céus! Não era possível! Eram borboletas! O detetive sempre tinha ouvido falar de lepidópteros semelhantes aos insetos das colmeias, na forma e no colorido, mas nunca tinha tido ocasião de observá-los pessoalmente. Num instante compreendeu tudo. As borboletas, aproveitando-se de sua semelhança com as abelhas, entravam na colmeia, matavam as larvas e roubavam o mel dos alvéolos (ALMEIDA, 1991, p. 55).

Por meio da história podemos entender como ocorre o funcionamento de uma colmeia, pois o detive Papílio é convidado para investigar a morte por estrangulamento de noventa e duas larvas. No decorrer dessa visita, diversas informações são passadas ao leitor. Vemos que as abelhas suam uma substância chamada cera para a confecção dos alvéolos ou celas da colmeia e que a alimentação das abelhas é baseada em néctar e pólen extraído das flores. A história informa que o mel é produzido a partir de parte desse alimento das abelhas em uma 
bolsa na parte superior do estômago. Depois de feito, o mel é regurgitado e serve de alimento para as larvas das abelhas. Na colmeia, cada abelha tem uma função, dentre elas estão as abelhas trabalhadoras, a abelha rainha, as princesas e os zangões.

No capítulo "Papílio na colmeia" (ALMEIDA, 1991, p. 48), podemos ler sobre as fases de desenvolvimento das abelhas (ovo, larva, inseto), a divisão de tarefas e de posições hierárquicas existentes na colmeia. Fala também sobre a reprodução (somente a abelha rainha deposita ovos nas celas: cerca de três mil por dia), além de curiosidades como o ácido que está localizado em uma pequena bolsa junto ao ferrão que em a função de conserva o mel, impedindo sua fermentação. Tal assunto pode ser lido no trecho seguinte em que a rainha da colmeia oferece um presente ao detetive Papílio:

\footnotetext{
- Leve este pequeno presente. O mel que está aí dentro foi feito com néctar dos mais perfumados e belos lírios do campo... - Majestade! Se possível, entretanto, preferiria que mandasse trocar o favo por outro menor. Receio muito que o mel se estrague com esse calor tão forte que temos tido. - Não há perigo, senhor Papílio. Todas nós possuímos, junto ao ferrão, uma pequena bolsa, donde é segregado um ácido que impede a fermentação do mel. Depositamos uma gotinha desse ácido em cada um das celas e, com essa precaução, nosso alimento se conserva perfeito por tempo indeterminado. Pode estar certo de que vai aproveitar o seu mel até o fim (ALMEIDA, 1991, p. 57).
}

Todos esses pontos levantados são, entre outros, os que conferem à narrativa um caráter ambíguo, que a mantém entre o didático e o maravilhoso, e a torna ímpar, pois conserva o leitor nesse trânsito entre a fantasia e o cientifico, uma vez que as informações científicas são passadas ao leitor por uma voz impessoal, destituída de magia, "a margem do texto - um paratexto - e do contexto maravilhoso que informa os dados científicos, mantendo deste modo, bem marcadas as linhas que separam os dois universos" (MENDONÇA, 2007, p. 101). A autora apresenta notas e um sumário onde são listadas as bibliografias de onde foram retiradas as informações passadas ao leitor no decorrer da narrativa, fortalecendo o caráter científico das informações e reforçando sua associação à escola, sendo assim, mais um ponto positivo a respeito do seu uso em sala de aula, como um recurso didático diversificado. Porém, não foi realizada nenhuma pesquisa a respeito da veracidade das informações apresentadas, cabendo ao leitor realizar uma leitura crítica, pois esse não foi o foco da pesquisa ao apresentar tais conteúdos.

\subsection{ESTABELECENDO RELAÇÕES ENTRE A PESQUISA CIENTÍFICA E A INVESTIGAÇÃO DO DETETIVE}


Conforme já dito, no decorrer da história, acontece de forma misteriosa o assassinato da noiva do príncipe Grilo, a borboleta Helicônia. Posteriormente a borboleta Vanessa Atalanta, por quem o Príncipe Grilo estava começando a se interessar também é assassinada. Para desvendar os assassinatos, o detetive Papílio possui muitas dúvidas e para solucioná-las, ele segue pistas e levanta hipóteses, que no decorrer da trama são confirmadas e refutadas. Esse encadeamento também ocorre na pesquisa científica e permeiam as investigações de cunho científico. Com base nisso, procuramos estabelecer uma relação entre a história da borboleta Atíria com um modo de construção da ciência.

Sendo assim, fizemos o levantamento de uma sequência de acontecimentos que ocorreram na floresta na forma de tópicos, para que posteriormente, por meio de analogias, pudéssemos fazer uma comparação entre os acontecimentos e as etapas da realização de uma pesquisa científica, possibilitando que o professor explique de forma mais facilitada tal conteúdo aos seus alunos.

\subsubsection{Tópicos}

Primeiro assassinato: a história começa relatando o assassinato da noiva do Príncipe Grilo, chamada Helicônia. Conforme as investigações do detetive Papílio, o corpo foi encontrado no Antro das Bruxas e Helicônia não tinha inimigos, tornando o caso muito misterioso.

Caligo suspeita que a morte de Helicônia tenha sido causada por aves que são muito comuns na região.

$\checkmark \quad$ Surge na floresta a borboleta Vanessa Atalanta que veio da Inglaterra.

Atíria, que era uma borboleta muito gulosa, se perdeu ao sair para procurar amoras, sua fruta preferida.

O Príncipe Grilo estava começando a se interessar pela borboleta Vanessa. Esse boato, que era muito comentado na floresta, que pode ser visto por meio da conversa entre o bicho pau e Atíria (ALMEIDA, 1991: p.29): “- Parece que nosso Príncipe anda enamorado, disse ele. Ouvi dizer que está estudando butterflish com a Senhorita Vanessa, e muita gente acha que isso acaba em casamento." 
$\checkmark \quad$ Segundo assassinato: A borboleta Vanessa Atalanta foi encontrada ao lado de uma planta até então desconhecida, agonizando no Antro das Bruxas e murmurando a palavra 'coruja'.

A planta que estava ao lado da borboleta era "Mancenilha", que nada mais é do que uma planta venenosa, conforme dito por Caligo.

Papílio levanta a hipótese de que Helicônia pode ter sido morta da mesma forma que Vanessa, ou seja, envenenada.

$\checkmark \quad$ Como não se sabia quem era o assassino, as corujas do bosque passaram a ser vigiadas, sendo uma forma de precaução para com os outros animais do bosque.

$\checkmark \quad$ Surge um boato de que há um fantasma que aparecia nas noites de Lua, no alto do morro. O detetive Papílio resolve verificar o caso e descobrir se tem alguma relação com as mortes.

O detetive descobriu que o fantasma se tratava de um inseto e que este fato nada tinha a ver com os assassinatos.

$\checkmark \quad$ Em um de seus voos noturnos, Papílio se perdeu pelo bosque e parou perto de uma pedra para descansar e acabou ouvindo a conversa de dois indivíduos. A conversa estava sendo realizada em 'insetês' (língua universal dos insetos), impedindo que o detetive pudesse fazer deduções a respeito das espécies de animais que conversavam. No decorrer da conversa, um dos indivíduos relatou ter matado Helicônia e Vanessa, sendo assim, uma conversa entre o assassino e seu cúmplice.

$\checkmark \quad$ A suposta coruja seria rainha e o outro iria matar os fracos, doentes e feios e escravizar o resto dos animais do bosque.

$\checkmark \quad$ A próxima vítima seria a borboleta Atíria.

$\checkmark \quad$ O cúmplice da possível coruja era um ser vivo que possuía um sistema nervoso que não suportava luz. Além disso, ele nasceu nas trevas e nela vivia.

$\checkmark \quad$ Para não atrapalhar as investigações o detetive resolveu não revelar nada a ninguém.

Em uma colmeia localizada perto do Antro das Bruxas surgem novos assassinatos. O detetive Papílio foi chamado pela Abelha Rainha para solucionar o caso das mortes de suas filhas.

O detetive descobriu que as assassinas das larvas eram duas borboletas semelhantes a insetos que tinham a coloração parecida com a das abelhas e que também imitavam os seus zumbidos. Esse fato acabou não sendo uma pista direta. 
$\checkmark \quad$ Durante um concerto no bosque, o bicho-pau riu tanto que acabou caindo do banco em que estava. Achando que ele havia desmaiado, Caligo voou para baixo, a fim de socorrê-lo. Neste instante algumas peças do quebra-cabeça se encaixaram e uma nova pista surgiu.

Com base nos dados que tinha, Papílio enviou uma carta para Atíria alertando-a dos perigos. Nesta carta é possível ver algumas suspeitas de Papílio: “Senhorita Atíria - não saia depois do Sol posto de modo algum. Fuja de corujas e de borboletas de voo crepuscular. Guarde reserva. Papílo (ALMEIDA, 1991, p. 62)”.

Atíria acabou se atrasando na volta para casa e notou estar sendo perseguida. No caminho ela encontrou Caligo que a enganou e a levou para dentro de uma gruta, onde revelou ser a assassina.

Com base nos dados que ele foi coletando em suas investigações, e no sumiço de Caligo, Papílio confirma ser Caligo a assassina.

Para desvendar esse mistério, pensar no mimetismo foi um dos passos mais importantes. $\mathrm{O}$ detetive pode ter sido estimulado por meio dos outros casos que sucederam no decorrer da investigação. Ao desvendar o mistério do fantasma, Papílio percebeu que alguns insetos se utilizam de artifícios para se proteger de presas. Já no caso das mortes que ocorreram na colmeia, Papílio verificou que alguns animais imitavam outros para roubarem seu alimento, utilizando o mesmo artifício do assassino, ou seja, se passando por outro animal. A assassina Caligo tinha uma marca nas asas que pareciam os olhos de uma coruja.

Para descobrirem o local onde Atíria estava aprisionada por Caligo, algumas pistas também foram utilizadas. Uma delas foi fornecida pelo Louva-a-deus e a outra pelo detetive Papílio. O mistério foi desvendado, porém, não é relatada no livro a forma como a borboleta Helicônia foi morta, deixando no ar as suspeitas de envenenamento.

\subsubsection{Interfaces entre a história e a pesquisa científica}

Fazendo uma analogia entre a história e uma pesquisa científica, podemos pensar em Atíria, o detetive Papílio e sua assistente Caligo como sendo os integrantes de um grupo de pesquisa científica. Conforme a história, os fatos são que duas mortes ocorreram na floresta, sendo assim, o objetivo da pesquisa seria desvendar quem é (são) o (os) assassino (os). Primeiramente ocorreu a morte da borboleta Helicônia. Baseado nisso, de dados 
experimentais iniciais para a investigação, só se sabia que a morte ocorreu no Antro das Bruxas, que a borboleta assassinada não tinha inimigos e que ela se tratava da noiva do Príncipe Grilo. A partir desses dados surge a hipótese de que a morte tenha sido causada por aves que são muito comuns na região.

Posteriormente, novos fatos surgem na floresta. A borboleta Vanessa Atalanta chega da Inglaterra, Atíria se perde ao sair para procurar amoras e o Príncipe Grilo começa a se aproximar mais de Vanessa. No decorrer da pesquisa, surge um novo dado experimental, a borboleta Vanessa Atalanta foi encontrada agonizando ao lado de uma planta venenosa, no Antro das Bruxas e murmurando a palavra 'coruja'. A partir dos novos dados, uma nova hipótese pode ser levantada, a de que Helicônia pode ter sido morta da mesma forma. Como forma de prevenção, até que a pesquisa seja concluída, as corujas do bosque passaram a ser vigiadas como precaução.

Surge um novo dado, o boato de que há um fantasma que aparecia nas noites de Lua, no alto do morro. O pesquisador Papílio resolve verificar o caso e descobrir se tem alguma relação com as mortes e descobre que o fantasma se tratava de um inseto e que este fato nada tinha a ver com os assassinatos, refutando assim tal hipótese. Em um de seus voos noturnos, Papílio ouve uma conversa em 'insetês' (língua universal dos insetos) entre o assassino e seu cúmplice, impedindo que o detetive pudesse fazer deduções a respeito das espécies de animais que conversavam. A partir dessa conversa, Papílio descobre que as mortes ocorreram porque os assassinos queriam atingir o Príncipe Grilo e que o intuito deles eram matar os fracos, doentes e feios e escravizar o resto dos animais do bosque e que a próxima vítima seria a borboleta Atíria. O cúmplice da possível coruja (assassina) era um ser vivo (cúmplice) que possuía um sistema nervoso que não suporta luz. Além disso, ele nasceu nas trevas e nela vive. Todos esses são mais dados experimentais para a pesquisa de Papílio. Com tais informações, o detetive resolveu não revelar nada a ninguém, nem aos seus companheiros de pesquisa.

Em uma colmeia localizada perto do Antro das Bruxas surgem novos assassinatos. $\mathrm{O}$ pesquisador Papílio vai até o local para solucionar o caso das mortes e para ver se há alguma ligação entre os casos. Após a análise da situação, Papílio acredita que não havia ligação entre as mortes das larvas de abelhas com as mortes de Helicônia e Vanessa. Além disso, ao solucionar outro caso, sua hipótese de que as assassinas das larvas eram duas borboletas semelhantes a insetos, que tinham a coloração parecida com a das abelhas e que também 
imitavam os seus zumbidos foi confirmada. Esse fato acabou não sendo uma pista indireta para o seu caso de investigação principal.

Posteriormente, durante um concerto no bosque, Caligo voa e isso faz com que Papílio tenha uma nova teoria, a de que Caligo seria uma das assassinas e que teria feito isso se disfarçando de coruja. Ela possuía o artifício do mimetismo, ou seja, ela ficava de costas, abria as asas e virava de cabeça para baixo, apresentando semelhanças físicas ou de comportamento. Normalmente, esse recurso é utilizado pela borboleta com o intuito de se proteger de seus predadores exibindo os mesmos sinais ou comportamentos de advertências das espécies perigosas que ela imita.

Podemos pensar que Papílio chegou a essa conclusão ao se lembrar do fato que ocorreu na colmeia e com o pássaro do alto do morro, porém desvendar que Caligo havia usado do mimetismo foi resolvido por meio das pesquisas bibliográficas que ele havia feito para a realização de sua pesquisa. Com base nos dados que o detetive Papílio foi adiquirindo no decorrer de sua investigação, ele provou que a morte de Helicônia também havia sido por envenenamento.

Para solucionar o mistério do lugar em que Atíria foi aprisionada, o pesquisador Papílio também se baseou em dados experimentais, como a pista fornecida pelo Louva-a-deus e a lembrança do lugar em que ele tinha ouvido a tal conversa esclarecedora na noite escuríssima.

Conforme vimos, por meio de analogias o professor pode explicar de uma forma diferenciada e simplificada aos alunos, uma das maneiras que os pesquisadores utilizam em suas pesquisas científicas. Tal atitude desmistifica a ideia de que a ciência é algo que está distante dos alunos e de que ela pode ser compreendida, caso seja explicada de uma forma mais esclarecedora.

Sabemos que a realização de uma pesquisa científica faz parte do conteúdo procedimental, que é caracterizado pelo estudo de técnicas e estratégias para o avanço do conhecimento proporcionado através da experiência do fazer. Para Zabala (1999, p.10), um conteúdo procedimental é provido de regras, de técnicas, de métodos, de habilidades, de estratégias e de procedimentos. “É um conjunto de ações ordenadas e com finalidade, quer dizer, dirigidas à realização de um objetivo". Esse é um dos três conteúdos apresentados por Antoni Zabala, sendo os outros, os conceituais e os atitudinais, que se referem respectivamente à construção ativa de capacidades intelectuais e à formação de atitudes e valores em relação à informação recebida (ZABALA, 1998, p.42). 
Essa análise que acabamos de fazer, também pode ser relacionada com os conteúdos necessários para a realização de uma investigação proposto no modelo de Pro Bueno que são: a formulação de um problema com base no contexto analisado; a formulação de uma hipótese, onde as ideias são testáveis; a coleta de dados; a identificação e o controle das variáveis que são relevantes ou irrelevantes para a solução do problema de pesquisa; as montagens experimentais para o teste das hipóteses, caso seja necessário; as técnicas de investigação que serão utilizadas; a análise dos dados por meio de recursos diversos e por fim, o estabelecimento da conclusão (et al CAMPOS,1999, p.48).

Para desvendar os assassinatos, o detetive Papílio possui muitas dúvidas e para solucioná-las, ele segue pistas e levanta hipóteses que no decorrer da trama são confirmadas e refutadas. Esse encadeamento também ocorre na pesquisa científica e permeiam as investigações de cunho científico.

Conforme vimos nos exemplos citados que permeiam o enredo da história, o professor pode explicar a produção da ciência fazendo uma interface com o romance policial, tornando o aprendizado mais fácil e simplificado, utilizando a analogia. Tal atitude desmistifica a ideia de que a ciência é algo que está distante dos alunos, favorecendo sua compreensão. Por meio da análise notamos que o romance policial é uma possibilidade didática na abordagem da temática investigação científica no ensino de ciências, pois a obra tem como foco central a busca do conhecimento por meio da investigação.

Esse método empírico apresentado é apenas um exemplo de produção científica, afinal, o método científico não é fechado, nem apenas empírico. Assim como dito por Chalmers (1993) não há uma definição fechada para a ciência, apenas um método. Porém, existem alguns consensos que são aceitos. Esse debate sobre outras formas de construção da ciência será apresentado adiante nas propostas didáticas para que seja debatido com os alunos.

Para entendermos melhor a obra $O$ caso da borboleta Atíria foram feitas algumas análises da obra, além do mais, tais estudos facilitam a elaboração de atividades didáticas com a obra. Iniciamos apresentando a análise do discurso da obra, tendo Maingueneau (2006) como aporte teórico, sem deixar de ressaltar que há outros autores que também utilizam dessa vertente de análise para entender o contexto de produção da obra. Posterioremente, abordamos as definições de enunciação e enunciado para que o enredo da obra e a análise semiótica nela realizada sejam entendidos. $\mathrm{Na}$ análise, buscamos entender as relações entre os personagens e seus objetos de valores, assim como o objetivo do discurso da obra. 


\section{CAPÍTULO 4: ANÁLISES}

Pretendemos nesse trabalho estudar as características do processo de produção da obra, que não podem ser negligenciados no contexto de ensino-aprendizagem. O estudo tem como aporte teórico, Maingueneau (2006), que estabelece parâmetros que permitem avaliar as principais características e as condições de êxito para os gêneros do discurso. Tais parâmetros foram utilizados com o objetivo de evidenciar elementos a serem considerados no processo de ensino-aprendizagem relacionados à estrutura da obra e ao contexto sociocultural em que está inserida.

A análise da obra literária foi proposta com o objetivo de ampliar a compreensão de sua produção face ao contexto sociocultural em que está inserida, além de evidenciar parte das características acerca do contexto e de sua estrutura, verificando se esta será uma boa possibilidade didática na abordagem de temas científicos. Também está sendo realizada uma análise baseada no uso da semiótica de Greimas (1976) e Pietroforte (2007) que procura estabelecer as relações sintáxicas no interior de um texto, podendo auxiliar um trabalho de interpretação mais profunda.

\subsection{CONDIÇÕES DE PRODUÇÃO DO DISCURSO DA OBRA}

A análise da obra literária foi feita a partir da estrutura mais formal do texto, com o intuito de estabelecer as implicações sociopolíticas nele veiculadas em relação a suas condições sociais de produção. Tal análise foi realizada a partir do conceito de gênero proposto por Bakhtin (2004) e principalmente pelos trabalhos de Maingueneau (2006) que considera que os gêneros textuais são atividades sociais que se submetem a critérios de êxito.

Para Bakhtin (2004), que examina a língua a partir do contexto social de sua produção, todo discurso deve ser analisado conforme sua função na comunicação entre os falantes. $\mathrm{O}$ discurso deve ser visto como portador de pressupostos ideológicos e intencionalidades inerentes à sua prática social. Os enunciados dos discursos devem ser interpretados a partir do seguinte contexto:

Toda enunciação, mesmo na forma imobilizada da escrita, é resposta a alguma coisa e é constituída como tal. Não passa de um elo em uma cadeia dos atos de fala. Toda inscrição prolonga aquelas que a precederam, trava uma polêmica com elas, conta as reações ativas da compreensão, antecipa-as (BAKHTIN, 2004, p. 98). 
Maingueneau (2006) estabelece parâmetros que permitem avaliar as principais características e as condições de êxito para os gêneros do discurso. Dentre os parâmetros - de uma finalidade, estatutos para os parceiros, circunstâncias adequadas, um modo de inscrição na temporalidade, a continuidade, o tempo de validade, um suporte, um plano textual e, certo uso da língua - foram selecionados alguns itens a serem utilizados em nossa análise. Contudo, antes da realização da análise propriamente dita com base nesses parâmetros, é necessário que se entenda o que é um gênero, para que posteriormente seja feita a caracterização da obra.

Para se caracterizar um gênero, devemos pensar em seu caráter histórico. $\mathrm{O}$ gênero possui características particulares que o diferenciam e que se manifestam em circunstâncias apropriadas. Os parâmetros normalmente empregados na definição de gênero nos estudos literários são bastante heterogêneos, separados em "historicamente definidos", "modos" ou “regimes enunciativos". Acerca disso, Genette (apud MAINGUENEAU, 2006, p.232) diz que "não existem arquigêneros que escapem totalmente à historicidade ao mesmo tempo em que conservam uma definição genérica. Existem modos, como a narrativa; existem gêneros, como o romance".

Entretanto, a noção de genericidade pode ser instável, afinal, a categoria gênero não é reservada apenas à literatura. Tal categoria não pode receber uma definição na literatura que não contemple outras produções verbais, como os discursos constituintes (MAINGUENEAU, 2006).

Conforme já dito, analisamos a obra embasados em alguns dos parâmetros propostos por Maingueneau (2006) sendo que, quando houve proximidade entre alguns deles, optamos pela sua junção:

- Uma finalidade: o gênero do discurso objetiva gerar alguma modificação da situação em que está sendo inserido. E saber qual é essa finalidade é importante para que o destinatário reaja adequadamente ao que for proposto.

Este ponto exige saber qual era o objetivo da autora e da editora ao escrever o livro. Sabemos que interesses comerciais estavam em pauta na época, pois o governo começou a adquirir títulos de literatura brasileira nas escolas, voltada para o público infantil.

Como a obra foi lançada na Série para atender em especial a demanda escolar, acreditamos que a obra foi bem aceita por fornecer subsídios para a educação formal, por meio da apresentação de conteúdos científicos. Tudo isso tendo como complemento as fichas de leitura, de modo a serem utilizada em sala de aula, conforme as determinações do MEC na década de setenta, assumindo assim um cunho didático. Talvez essa não tenha sido a intenção 
da autora, afinal, seu livro havia sido publicado anteriormente em outra editora, porém, pode ter sido um dos fatores determinantes de seu grande sucesso de venda.

- Estatutos para os parceiros: a fala em um gênero do discurso parte de um indivíduo de um dado estatuto a outro indivíduo. O estatuto está relacionado a determinados direitos, deveres e saberes. Pensando nisso, quando se escreve um artigo científico, subtende-se que seu leitor seja diferenciado do grande público, pois este deverá ter conhecimentos que o possibilite a realização de tal leitura. Quanto à obra literária, esta foi criada em um período em que os textos literários nacionais passaram a ser obrigatórios para o ensino de Língua Portuguesa, e a editora da qual a obra faz parte acompanhou a tendência da época, fazendo uma ponte entre a Escola e a Literatura. Sendo assim, ela é destinada em especial ao público jovem, que a lerá tanto no espaço escolar como fora dele. Mas ao se analisar com base no ponto de vista da época, e pensarmos nas suas intenções, conclui-se que a obra também é destinada aos professores, que são os mais interessados no seu uso em sala de aula. Sendo assim, a obra tinha o dever de agradar não só o público infanto-juvenil como também aos professores. Com base nesses pressupostos, podemos pensar que o intuito da autora em se atentar à realização de toda uma pesquisa científica e apresentar em seu enredo conteúdos que podem ser trabalhados em sala de aula, foi feita de forma proposital, para atender os interesses da época.

\section{- Circunstâncias adequadas e modo de inscrição na temporalidade.}

Circunstâncias adequadas: qualquer gênero do discurso acarreta em "momento" e "lugar" apropriados para seu êxito, que por sinal são fatores constitutivos, não coerções “externas". Dependendo do tipo de produção, o contexto muda e isso pode ser visto na comparação entre o texto escrito e o texto oral.

- Um modo de inscrição na temporalidade: estabelece que algo pode acontecer baseado em eixos como a periodicidade e a duração, sendo, respectivamente, os intervalos do discurso que podem ser regulares (missa) ou não (pronunciamento de chefe do estado) e a duração de um gênero do discurso, que pode chegar a envolver até mesmo duas durações, como acontece no decorrer da leitura de um jornal. Tal leitura pode ser restrita apenas aos elementos em negrito ou a leitura de todo o texto.

O livro é escrito em meio impresso, porém escrito de uma única vez, não sendo dividido em vários volumes como acontece em uma coletânea, tendo início e fim nele mesmo. A história é dividida em capítulos, com aproximadamente a mesma quantidade de páginas, que gira em torno de três. Os capítulos são: Atíria; A folha falante; O Príncipe Grilo, Caligo e 
Papílio; Vanessa Atalanta; Aventura; A nuvem negra; O galho mágico; Mistério; O fantasma; Um pouco de luz; O parque de diversões; Papílio na colmeia; O concerto; Perigo; A gruta dos horrores; Lá fora; O esqueleto vivo; Chegariam tarde?; Esclarecimento; As bodas; e Bibliografia. Tais características são compartilhadas por outros livros da Série Vaga-Lume, sendo assim, um padrão estipulado aos escritores.

- Um suporte: é a forma pela qual o texto é apresentado, podendo ser um livro, um manuscrito, na memória de um computador, em disquete, etc. O texto nada mais é do que a unidade formada entre o conteúdo e o seu modo de existência material. Ao se modificar o suporte material, há a modificação do gênero do discurso, como ocorre quando um livro é transformado em filme.

A obra $O$ caso da borboleta Atíria é feita em forma de livro e faz parte de uma coleção que possui um padrão seguido por todos os outros livros que ela publica, como, a quantidade de páginas (limite de espaço), o formato e o tamanho da fonte, a presença de desenhos com tamanhos e características comuns. Um diferencial não só apenas dessa obra, mas que no geral aparece em algumas outras, é a presença da bibliografia, apresentando as fontes pesquisadas pela autora. Além disso, em todas as obras da Série consta a biografia dos autores e em alguns há também a dedicatória. Na contracapa de cada livro encontram-se as imagens dos outros livros que fazem parte da Série, como forma de sugestão ao leitor.

- Certo uso da língua: Por haver uma imensa variedade linguística (diversidade de línguas, dialetos, variedades sociais, variedades profissionais, etc.), cada gênero do discurso pode ter a ele associado um desses diversos tipos, podendo nesse caso se tornar uma norma ou pelo contrário, não ter imposto um específico uso linguístico, como acontece na literatura contemporânea.

Nota-se que na obra, as falas - ou discursos - são estruturadas por meio do discurso direto, pois no decorrer da narração, há a reprodução da fala dos personagens. A linguagem é culta e acessível ao público infanto-juvenil e aos professores que utilizarem o recurso em sala de aula.

- O tempo de validade: Alguns gêneros do discurso possuem validade, como por exemplo, um jornal diário que tem a duração de um dia, diferente de um texto religioso que é indefinidamente legível.

O livro apresenta uma história que só perderá sua validade caso os conteúdos apresentados não sejam mais aceitos socialmente ou didaticamente, com a mudança do 
currículo. A autora apresenta conteúdos científicos, que são suscetíveis a mudanças, caso novas descobertas sejam feitas por meio dos avanços das pesquisas científicas.

A análise da obra, por meio dos parâmetros de Maingueneau (2006), com o intuito de estabelecer as implicações sociopolíticas nele veiculadas em relação a suas condições sociais de produção, foi importante para que houvesse um melhor entendimento das intenções e pretensões da autora, pautadas no contexto social de sua produção, afinal todo gênero do discurso é portador de pressupostos ideológicos e de intencionalidades inerentes à sua prática social.

É importante salientar também que os discursos são sempre constituídos e dirigidos a um interlocutor. No caso da obra analisada, tendo como pressuposto o contexto, notou-se que o público alvo da obra em especial, era/é o público jovem pertencente ou não ao espaço escolar, assim como os professores. Sendo assim, a linguagem da obra deveria se adequar a esse público leitor.

\subsection{A ENUNCIAÇÃO E O ENUNCIADO}

Sabemos que a comunicação é indispensável para os seres humanos e que esta é realizada por meio de diversas manifestações linguísticas, como a escrita, a oralidade, os sons, as expressões fisionômicas, nas artes plásticas, etc. Para Bakhtin (1997, p. 290), tais diversidades de manifestações existem devido às abundantes esferas da atividade humana. Porém, todas essas esferas da atividade humana estão sempre relacionadas com a utilização da língua.

A utilização da língua efetua-se em forma de enunciados, que não é uma palavra, uma frase ou um aglomerado de frases, mas um conjunto de ideias que, em contexto, dão sentido ao discurso. A esse respeito, Fiorin (1999, p. 30) diz que o enunciado é "um todo de significação", produto da enunciação (2011, p. 55) que "é o ato de produção do discurso, que ao realizar-se, deixa marcas no discurso que constrói”. Pietroforte (2007, p. 19), acrescenta que a enunciação, entendida como ato de linguagem, para ser realizada necessita de um enunciador e um enunciatário, "cuja relação produz a enunciação".

No livro "Marxismo e filosofia da linguagem" (1997), Bakhtin utiliza em certos momentos a palavra enunciação como sendo o ato da fala e é vista com a realização exterior da atividade mental do enunciador. 
A enunciação realizada é como uma ilha emergindo de um oceano sem limites, o discurso interior. As dimensões e as formas dessa ilha são determinadas pela situação da enunciação e por seu auditório. A situação e o auditório obrigam o discurso interior a realizar-se em uma expressão exterior definida, que se insere diretamente no contexto não verbalizado da vida corrente, e nele se amplia pela ação, pelo gesto ou pela resposta verbal dos outros participantes na situação de enunciação (BAKHTIN, 1997, p. 125).

A partir deste trecho, nota-se que Bakhtin apresenta a questão do contexto ou situação na qual um enunciado é produzido, possibilitando que seu sentido estabeleça uma relação de significação entre os interlocutores.

Sendo assim, para Bakhtin (1997, p. 14), por meio da enunciação, a interação verbal é realizada como fenômeno social, afirmando que "a fala está indissoluvelmente ligada às condições de comunicação, que, por sua vez, estão ligadas às estruturas sociais".

O enunciado, produto de uma enunciação, compõe o discurso realizado pelo enunciador, sendo uma frase ou oração que vai além de sua forma fonética ou morfológica, pois, levando em conta apenas esses dois fatores, não haverá um enunciado completo. $\mathrm{O}$ enunciado implica também em uma relação verbal entre dois sujeitos, na existência de um sujeito que enuncia e de um sujeito que recebe essa informação. Isso significa que o ato de enunciar pressupõe dizer alguma coisa a alguém, dentro de uma competência linguística e discursiva. Sendo assim, o discurso é uma relação verbal entre enunciador "sujeito que realiza um ato de enunciação" e o enunciatário "a quem o locutor dirige um ato de fala numa situação de comunicação".

Segundo Fiorin (2011, p. 56), a enunciação “define-se como a instância de um 'euaqui-agora", pois ela é uma instância que perpassa por um enunciado de pessoas (actorialização), de tempos (temporalização) e espaço (espacialização):

O $e u$ instaurado no ato de dizer: $e u$ é quem diz eu. A pessoa a quem o $e u$ se dirige é estabelecida como tu. O eu e o tu são os actantes da enunciação, os participantes da ação enunciativa. Ambos constituem o sujeito da enunciação porque o primeiro produz o enunciado e o segundo, funcionando como uma espécie de filtro é levado em consideração pelo $e u$ na construção do enunciado. Com efeito, a imagem do enunciatário a quem o discurso se dirige constitui uma das coerções discursivas a que obedece o enunciador: não é a mesma coisa produzir um texto para um especialista em uma dada disciplina ou para um leigo... $\mathrm{O}$ eu realiza o ato de dizer num determinado tempo e num dado espaço. Aqui é o espaço do $e u$, a partir do qual todos os espaços são ordenados (aí, lá, etc.); agora é o momento em que o eu toma a palavra e, a partir dele, toda a temporalidade lingüística é organizada (FIORIN, 2011, p. 56)

A partir do trecho nota-se que Fiorin exemplifica como são projetados para o leitor, a partir do discurso, os seus atores, assim como, suas coordenadas espaços-temporais. Salienta 
também a importância dada pelo enunciador ao enunciatário, pois ao escrever uma obra, o autor leva em consideração o seu público leitor, afinal o produto de sua escrita, o enunciado, a ele é direcionado. Fiorin acrescenta ainda que a produção de seu discurso é feita de forma persuasiva com a intenção de fazer com que o enunciatário aceite o que ele diz, se apropriando de "procedimentos argumentativos", em contrapartida, "o enunciatário realiza um fazer interpretativo" (FIORIN, 2011, p. 57).

Fiorin também fala a respeito das condições de verdade dos atos de linguagem que se realizam pela enunciação (1999, p. 35) relatando que ao se produzir um enunciado, “estabelece-se uma 'convenção fiduciária' entre enunciador e enunciatário, a qual determina o estatuto veridictório do texto". Isso significa dizer que o enunciador reconhece o dizerverdadeiro da enunciação destinada ao enunciatário.

Conforme apresentado anteriormente, o enunciado não é uma frase qualquer, mas uma frase constituída de sentido no nível de interpretação e é caracterizado conforme o contexto em que é pronunciado. Tal enunciado possui um objetivo de comunicação que neste trabalho será analisado e refletido no discurso literário.

\subsection{ANÁLISE SEMIÓTICA}

Os estudos do discurso fornecem diversas abordagens que, embora possam ser empregadas isoladamente, quando aplicadas a um mesmo conjunto de textos podem auxiliar em um trabalho de interpretação mais profunda. Um desses instrumentos é a semiótica estruturalista que estuda a significação ao procurar estabelecer relações sintáxicas no interior de um texto.

Dentre os trabalhos que utilizam a semiótica de Greimas podemos destacar o seu uso como ferramenta de análise do discurso científico por Latour (1988); como referencial no processo de ensino-aprendizagem (PIKKARAINEN, 2010); como instrumento de análise em livros didáticos por Piassi (et al., 2009); como meio de promover à —acessibilidade da ciência através de divulgação científica (LOWREY; VENKATESAN, 2008, p. 253) e para analisar o discurso de professores em cursos de formação continuada (SANTOS et al, 2010). Sendo assim acreditamos que o instrumental fornecido pela análise semiótica greimasiana favorece a interpretação do texto do romance assim como dos próprios objetos de valores 
inerentes à investigação científica.

Segundo Souza, Algirdas Julien Greimas (1976) é o representante mais fiel da análise estrutural, sendo utilizada nas análises em diversas áreas como a literária, a pintura, a música, os anúncios publicitários, entre outros (SOUZA, 2006, p.54). Por isso, antes de se começar uma análise, Pietroforte (2007) diz que temos que pensar no plano de expressão e no plano de conteúdo, sendo que o primeiro pode ser verbal ou não e refere-se a forma de manifestação do conteúdo e o segundo diz repeito ao significado do texto, ou seja, "o que o texto diz e como ele faz para dizer isso", por isso podemos dizer que o sentido está nesse plano. A partir disso, o sentido pode ser analisado por meio da semiótica, que buscará entender a significação, a forma como esse texto foi feito, pois para Greimas, o sentido é entendido como um processo gerativo (PIETROFORTE, 2007, p.11).

Nesse percurso gerativo de sentido o discurso encerra uma dinâmica entre actantes (personagens), objetos e programas narrativos, onde o sentido é estabelecido por meio da criação de uma rede de relações. De acordo com Fiorin, o percurso gerativo pode ser definido em três níveis, o narrativo, o fundamental (profundo) e o discursivo (FIORIN, 2011, p.11).

Refletindo sobre no plano de expressão da obra, notamos que ela possui um sistema de significação verbal por se tratar de um romance. A forma pela qual o livro foi escrito e a história propriamente dita, que começa com os assassinatos, depois com o relato das investigações até que por fim, acontece a descoberta dos assassinos é o plano de conteúdo. A manifestação do conteúdo é feita em forma de narrativa, onde o leitor está passo a passo com o investigador (detetive), porém, nem sempre está por dentro de todos os seus pensamentos tornando a leitura mais atrativa.

$\mathrm{Na}$ história, os personagens estabelecem uma rede de relações voltada para o tema investigação. A partir desse tema desenvolve-se uma narrativa em que os sujeitos estão em busca de seus objetos de valor. Nessa análise vamos nos atentar a um personagem, o detetive Papílio.

\subsubsection{Nível narrativo}

O nível narrativo se refere às transformações de estados do percurso gerativo de sentido, que implica na transformação do estado de um actante em relação a um objeto-valor. 
Uma narração completa contaria com ao menos dois actantes (PIETROFORTE, 2007, p.17) e quatro fases, "a manipulação, a competência, a performance e a sanção (FIORIN, 2011, p. 29)".

Ao analisar a história, que por sinal é extensa, notamos que há diversos sujeitos com seus respectivos objetos de valor e antissujeitos relacionados, tendo como exemplos, Atíria, Papílio e o Príncipe Grilo, porém, como a princípio, o detetive será o sujeito foco da análise. O actante Papílio é o representante do investigador que busca o conhecimento para desvendar a mistério da história, indo de encontro com a proposta da busca pelo conhecimento por meio da investigação científica proposta na realização de uma pesquisa.

O detetive Papílio almeja desvendar o mistério, descobrir o assassino tendo o "saber" como objeto de valor. A falta de informação, as pistas erradas e os problemas diversos que atrapalham a investigação são exemplos de antissujeitos. Do lado oposto da trama, encontram-se os assassinos, que tem por objetivo usurpar a posição do príncipe Grilo e dominar o reino, fazendo com que todos sejam seus escravos, mostrando ter como foco a busca pelo "poder". Isso significa que, descobrir quem é o assassino será uma forma de impedir que futuras mortes ocorram, e toda essa trama e é um exemplo de uma rede de relações existente nas histórias.

Conforme Fiorin (2011, p. 30), há manipulações de diversos tipos, sendo os mais comuns: "a tentação, a intimidação, a sedução e a provocação". A tentação implica no oferecimento de uma recompensa ao destinatário da manipulação, já a intimidação se vale de uma ameaça para conseguir seu objetivo. Nos dois casos, o manipulador se vale do seu poder para o convencimento do destinatário. A sedução, por outro lado, ocorre quando o actante manipulador valoriza ou elogia o actante manipulado para convencê-lo a cumprir o programa narrativo proposto, enquanto que a provocação o incita à ação por meio de desafios morais que colocam em dúvida sua competência. Nesses dois casos, o manipulador está se valendo de seu saber como instrumento de convencimento.

A competência seria o "saber e/ou poder fazer" que o personagem dispõe, a performance se refere à "fase em que se dá a transformação central da narrativa" operada pelo sujeito e a sanção é a "constatação de que a performance se realizou...o reconhecimento do sujeito que operou a transformação" (FIORIN, 2011, p.30).

Tendo como foco as etapas de manipulação, competência, performance e sanção, 
podemos dizer que o que manipula Papílio a desvendar o mistério é sua amizade pelo ao príncipe e em razão de sua função de detetive no reino. Além disso, o detetive é manipulado por meio da intimidação de que se ele não encontrar o assassino, outros animais do reino irão morrer. Para que a performance do detetive em descobrir o crime seja satisfatória, ele precisará adquirir por meio dos programas de uso, a competência (saber e poder) necessária para a realização de tal fato, ou seja, adquirir pistas por meio da investigação. O detetive Papílio é competente no sentido de ter conhecimento para fazer sua investigação (é famoso, tem estudos, experiência) realizando sua performance, porém, ele não tem o conhecimento de quem é o assassino (saber). Nesse caso, a competência pertence aos assassinos.

Fazendo uma breve analise sobre os outros actantes da história, podemos levantar dois exemplos: os assassinos e a borboleta Atíria.

Ex 1: No início da história, os assassinos não possuem seu objeto de valor, que seria a posição do príncipe (poder). Para obter esse poder é necessário que todos que atrapalham os planos do assassino morram. Sendo assim, o antissujeito dos assassinos, ou seja, aqueles que atrapalham o alcance de seu objetivo são a Noiva Helicônia, a pretendente do príncipe Vanessa, a borboletinha Atíria e qualquer um que atrapalhe seus planos.

Ex 2: Depois que Helicônia e Vanessa são mortas e o detetive Papílio descobre que a próxima vítima será Atíria, ela entra num estado vida-não vida, pois sua vida não lhe pertence mais, está em risco (dentro da gruta), nas mãos dos assassinos, que em certo momento da trama, a mantém presa no cativeiro. Para que Atíria volte ao estado inicial de vida, ou seja, quando ela não correrá mais risco, depende da ação de Papílio e dos outros personagens em descobrir onde ela está presa e salvá-la da morte.

Quanto à etapa de manipulação, notamos que o que manipula Atíria a desvendar o mistério para ajudar o príncipe é seu sutil interesse por ele. Já Caligo e o Esqueleto-Vivo são manipulados pelo interesse de dominar o reino. Esses dois exemplos de manipulações são respectivamente positivo "prêmio" e negativo "castigo".

Em relação a performance dos actantes da história, podemos citar o assassino Caligo que usou de seu mimetismo, para se livrar de acusações e enganar quem estava investigandoo, passando a ideia de que o assassino se tratava de uma coruja. Em relação à competência, tem-se como exemplo o esqueleto vivo, que detinha o saber de tudo que estava acontecendo sem mesmo sair de dentro da gruta, graças a seu "poder da visão", porém, isso não foi suficiente para concluir e realizar sua performance. 
A junção de competência e performance geram a ação, a trama da história. A sanção seria o fechamento da história, ou seja, descobrir quem é (são) o(s) assassino(s), da história e Atíria casar-se com o príncipe.

A articulação entre, ser verso parecer, gera as modalidades veridictórias usadas no percurso gerativo de sentido. Quando algo parece, mas não é, chama-se mentira - Ex: Parece que o assassino é uma coruja, mas é uma borboleta. Quando algo é, mas não parece, trata-se de um segredo - Ex: O assassino é uma borboleta.

\subsubsection{Nivel fundamental}

O nível fundamental refere-se à história do livro e é estruturado pela categoria semântica, fundamentada em uma diferença, em uma oposição. "No entanto, para que dois termos possam ser apreendidos conjuntamente, é preciso que tenham algo em comum e é sobre esse traço comum que se estabelece uma diferença" servindo de base na construção de um texto. As categorias opostas são a euforia (qualidades positivas) e a disforia (qualidades negativas) sendo formalizadas no modelo do quadro semiótico (PIETROFORTE, 2007, p.14). O quadrado semiótico ilustra como o percurso narrativo configura a passagem de uma situação de conjunção a um objeto-valor, sua negação (contraditório) que implica na disjunção ou perda (virtual, iminente ou concretizada) do valor e, finalmente, a possível conjunção ao valor contrário.

Segue um exemplo de quadrado semiótico apresentado por Noth (1996, p. 154 apud SOUZA, 2006, p.59):

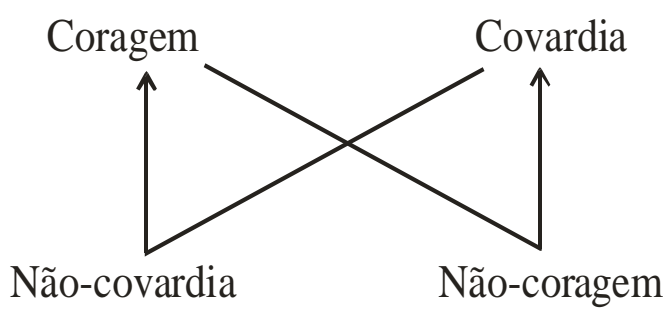

Figura 1 Quadrado semiótico

O quadrado semiótico mostra que o percurso narrativo se refere à passagem de uma 
situação de conjunção a um objeto-valor, em seguida ocorre sua negação (contraditório) que implica na perda ou disjunção (virtual, iminente ou concretizada) do valor e, por fim, a “possível conjunção ao valor contrário” (PIASSI, 2009, p.5).

A respeito da narrativa científica, Greimas relata que seu discurso científico apresenta uma "aventura cognitiva" que deixa evidente que o objeto-saber é o objetivo do discurso, ocorrendo a "transformação de um não-saber em um saber" (GREIMAS, 1976b, p. 11).

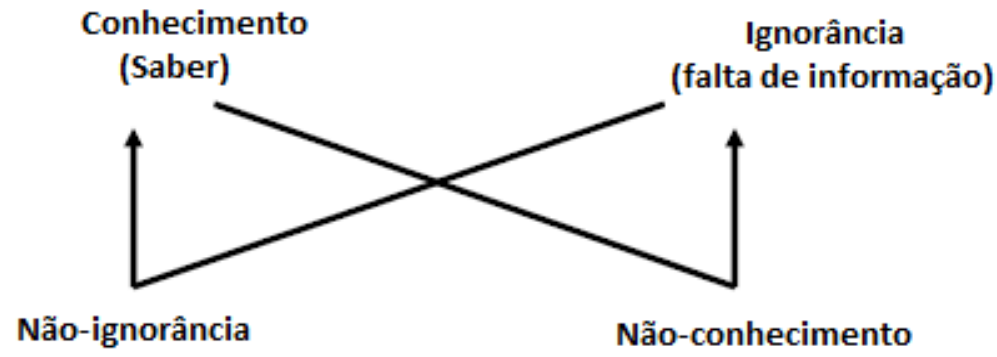

Figura 2 Quadro semiótico saber/ versus/ ignorância

Pensando no nível fundamental, percebemos que na história de Atíria, a categoria semântica seria a busca do saber (conhecimento), para que o mistério seja desvendado, por isso, podemos dizer que existe uma relação contrária entre Conhecimento x Ignorância. Fazendo uma analogia com a investigação científica, obtemos a relação Conhecimento científico x Senso comum. Essa relação contrária pode ser observada no quadro semiótico anterior.

\subsubsection{Nível discursivo}

Segundo Fiorin (2011, p. 41), no nível discursivo as "formas abstratas do nível narrativo são revestidas de termos que lhe dão concretude", sendo exemplificada na seguinte passagem:

A conjunção com a riqueza aparecerá no nível discursivo como roubo de joias, entrada na posse de uma herança, descoberta de uma mina de ouro, aplicação bemsucedida na Bolsa de Valores, recebimento de um grande prêmio de uma loteria, etc (FIORIN, 2011, p. 41). 
Pietroforte salienta ainda, que no nível discursivo ocorre a formação do processo de enunciação e as categorias de pessoa, tempo e espaço ganham investimentos semânticos, "que podem ser temáticos ou figurativos". O tema se refere ao assunto central da história e o figurativo, ao tipo de discurso que as figuras da história criam (PIETROFORTE, 2007, p. 21).

O plano de conteúdo, que se refere ao percurso gerativo de sentido, é veiculado por meio de um plano de expressão, sendo que esse pode se apresentar em "diferentes naturezas: verbal, pictórica, etc.”. Fiorin (2011) acrescenta que,

o percurso gerativo é um modelo que simula a produção e a interpretação do significado do conteúdo. Esse modelo mostra aquilo que sabemos de forma intuitiva: que o sentido do texto não é redutível à soma dos sentidos das palavras que o compõem nem dos enunciados em que os vocábulos se encadeiam, mas que decorre de uma articulação dos elementos que o formam - que existem uma sintaxe e uma semântica do discurso (FIORIN, 2011, p. 44).

Porém, para que esse modelo se manifeste é necessário a sua junção com um plano de expressão e essa união á chamada de manifestação. Segundo Fiorin (2011), o texto é a manifestação do conteúdo por meio de um plano de expressão. Essa distinção é apenas metodológica, afinal "não existe conteúdo sem expressão e vice-versa. Ela é realizada porque um plano de conteúdo pode ser veiculado por diferentes planos de expressão, como acontece quando uma obra é veiculada verbalmente (um livro de romance) ou/e verbalmente, pictoricamente, etc.: (um filme)".

Na história, as categorias de pessoa, tempo e espaço recebem investimento semântico figurativo, pois as figuras criam uma ilusão de um mundo possível, e isso pode ser notado quando são feitas referências ao mundo natural. Sendo assim, os personagens são figuras de um discurso figurativo. Temos como exemplos de figuras do discurso alguns animais que fazem parte do enredo, como as borboletas Atíria, Caligo e Papílio; e o grilo na figura do príncipe. Essas figuras recobrem o tema principal investigação.

O livro $O$ caso da borboleta Atíria foi escrito de uma única vez, ou seja, não é dividido em vários volumes como acontece em uma coletânea, tendo início e fim nele mesmo. A história é dividida em capítulos e conta com uma linguagem acessível. A forma pela qual o livro foi escrito e a história propriamente dita, que começa com os assassinatos, depois com o relato das investigações até que, por fim, acontece a descoberta dos assassinos é o que Greimas (1976) denomina, plano de conteúdo. O texto é uma relação entre um plano de expressão e um plano de conteúdo. O plano de expressão ocorre em um sistema de 
significação verbal, ou seja, a língua. A narração da história é o trânsito entre a fantasia e o cientifico.

Já o sentido do texto é definido como sendo uma rede de relações. Na história, as relações estabelecidas entre os personagens (Atíria, Papílio, etc.) e os demais elementos que compõe o discurso, adquirem sentido nas relações que estabelecem sua coerência. No decorrer da narrativa, Papílio, Atíria e o Príncipe Grilo, querem desvendar o mistério da morte de Helicônia e Vanessa. Para isso, precisam descobrir quem é o assassino. Neste caso, percebemos que há a busca pelo saber, ou seja, o conhecimento de quem é o assassino (s), do (s) motivo (s) que o levaram a cometer os crimes e quais suas intenções.

Do lado oposto da trama, encontramos os assassinos, que tem por objetivo usurpar a posição do príncipe Grilo e dominar o reino, fazendo com que todos sejam seus escravos, e para isso, irão matar qualquer um que tentar impedi-los. Neste caso, há a busca pelo poder. Isso significa que, descobrir quem é o assassino será uma forma de impedir que futuras mortes ocorram, e toda essa trama e é um exemplo de uma rede de relações existente nas histórias.

A história é narrada em terceira pessoa, conforme o trecho a seguir: "Num bosque cheio de pássaros e flores...”. Então o enunciador e o enunciatário estão implícitos no enunciado. Trata-se de uma enunciação enunciva, pois ocorre entre a autora e o cientista. $\mathrm{Na}$ enunciação o tempo no início da história é o passado, onde conta-se a respeito do nascimento da Atíria "Dito e certo, a borboleta tinha nascido com um desvio qualquer nas asas". Dois meses depois é o presente da história, e dessa forma segue até o final da história, sendo assim a enunciação enunciva do tempo presente, como por exemplo, o trecho: "Um ruído inesperado a fez olhar para a árvore vizinha, descobrindo Atíria toda escondidinha”. E o espaço é o aqui.

As figuras podem recobrir um ou mais temas. No caso da história de Atíria, perpassa por vários temas, como, investigação, relações sociais (ex: entre o príncipe e a camponesa), relação entre predador e presa (borboleta e coruja), adoção (Dona Jitirana adota Atíria), romance, entre outros.

Com base nas análises feitas da obra literária, ficam mais claras suas possibilidades didáticas, afinal a história de Atíria perpassa por vários temas, sendo a investigação apenas um deles, possibilitando um trabalho interdisciplinar em conjunto com outras áreas do conhecimento. 


\section{CAPÍtulo 5: Possibilidades e Propostas}

Entender que na história há a presença de diversos sujeitos com seus respectivos objetos de valor e antissujeitos relacionados amplia as possibilidades de elaboração de atividade. Estabelecer essas relações nas atividades tem por objetivo auxiliar o realizador das atividades e melhorar o seu entendimento sobre o enredo da história, possibilitando-o relacioná-la com a pesquisa científica, a desvendar o crime e a se colocar na situação de investigador pesquisador, que levanta hipóteses que são refutadas ou corroboradas com o objetivo de obter seu objeto de valor, o conhecimento. Entender o conceito de manipulação é importante na confecção das atividades porque se pode pensar a frente do realizador das atividades, levando em consideração quais seriam as circunstâncias que incentivariam a realização das atividades.

\subsection{IMPLICAÇÕES E PROPOSTAS DIDÁTICAS}

O uso da obra $O$ caso da Borboleta Atíria no ensino de Ciências foi proposto porque ela exige do leitor um espírito investigativo, uma vez que apresenta em seu enredo: problematização de situações e o trabalho com hipóteses na busca de soluções de problemas. O leitor exercita sua linguagem verbal ao se deparar com textos de tipos diferentes (termos e conteúdos científicos) enquanto interage com códigos e características próprios de outras linguagens. No decorrer da leitura, o leitor também pode se identificar com os personagens nas diferentes vertentes trabalhadas no livro como, família, desejos, postura frente ao adulto, o gosto pelo desafio, e a possibilidade de auto-avaliação.

Com o intuito de visualizar resultados referentes as proposta levantadas nesse trabalho foram elaboradas atividades didáticas de cunho educacional que possam ser aplicadas no ambiente escolar, com a finalidade de obtenção de parâmetros avaliativos. Tais propostas foram pensadas com o intuito de obter dos participantes pesquisados suas visões a respeito do uso da obra no ensino de como é feita a construção da ciência e avaliar o teor de eficácia das propostas nesse sentido. Além disso, as propostas buscam auxiliar a atuação e as competências envolvidas dentro da sala de aula, tanto para entender quanto para aperfeiçoar a elaboração dos planos de aulas dos educadores. Entendemos que a elaboração dessas 
propostas vai de encontro com a ideia de Paulo Freire (2006, p. 47), de que "Ensinar não é transferir conhecimento, mas criar as possibilidades para a sua própria produção ou sua construção".

As propostas terão com base as ideias de Antoni Zabala (1998) como instrumento de ajuda no trabalho em sala de aula, abordando os conteúdos em três naturezas: os conceituais, os procedimentais e os atitudinais. O conteúdo conceitual refere-se ao que se aprende, ou seja, o saber, que ao ser trabalhado amplia-se ao saber fazer, que faz parte dos conteúdos procedimentais e por fim, constrói-se um conjunto de valores que fazem parte da personalidade do indivíduo formando o seu ser, sendo assim, os conteúdos atitudinais. Tais conteúdos devem ser trabalhados dentro de um modelo de percepção da realidade da aula, onde estão estreitamente vinculados o planejamento, a aplicação e a avaliação.

Essas propostas terão como tema central a investigação científica. Tal conteúdo conceitual será abordado por meio de analogia tendo a literatura juvenil como recurso material principal e presente em todas as propostas. As propostas podem ser aplicadas isoladamente ou em conjunto, formando assim, sequências didáticas, cabendo ao professor utilizá-las conforme seu objetivo pedagógico.

Sendo assim, propomos aos professores atividades para serem aplicadas com seus alunos conforme suas necessidades e objetivos, ou seja, não havendo a necessidade de que todas sejam aplicadas nem que as sequências sejam seguidas a risca, conforme elas são apresentadas, e que forneçam ferramentas e novidades para enriquecer as aulas sobre investigação científica, com o intuito também de aumentar o interesse, a conscientização e atualização dos alunos. Elas também poderão ser complementadas por outras que o professor julgar pertinentes, tendo em vista seu planejamento e proposta de ensino, ou seja, essas atividades servirão de apoio às aulas para que sejam exploradas as competências e habilidades para a compreensão do saber e a apreensão dos alunos.

As propostas privilegiam os conteúdos procedimentais de leitura, realização de tarefas, debates e escrita, e realização de experimentos e objetivam fazer com que os alunos cultivem os conteúdos atitudinais de cooperação, de solidariedade, gosto pelo trabalho em grupo e pela leitura, e a obtenção de valores como o respeito e a ética.

Outro ponto privilegiado nessas propostas é a possibilidade de um trabalho interdisciplinar, pois a obra literária possibilita o trabalho com professores de disciplinas diversas. Também podem ser trabalhados conteúdos transversais, cabendo ao professor adaptá-los e abordá-los. 
Propomos o uso de diferentes metodologias, como é o caso da formação de grupos, que irá estimular os alunos a interagirem entre si. Também propomos o uso de discussões com a sala toda para incentivar os alunos a expressarem seus pontos de vista sobre as questões em debate. Também haverá propostas práticas que irão possibilitar ao aluno uma maior interação com o objeto de estudo, podendo facilitar o entendimento dos processos que permeiam o conteúdo ao refletirem sobre o assunto.

A avaliação será feita de acordo com o propósito da aula. Quando a aula estiver baseada em conteúdos atitudinais ou experimentais, será avaliada a atitude e a postura dos alunos durante a realização das tarefas e na apresentação dos resultados, bem como o engajamento apresentado na discussão inicial. A escrita dos alunos na realização de tarefas que trabalham conteúdos conceituais também serão objetos de avaliação. Cabe ressaltar a importância da realização de avaliações diagnósticas sobre o assunto antes e depois de sua aplicação. Sabemos que a avaliação é fundamental e importante no processo de ensino aprendizagem, além disso, é uma avaliação do trabalho docente, por isso, é importante escolher com cautela o método avaliativo conforme o objetivo desejado.

Tal atividade tem como público alvo alunos do $5^{\circ}$ ano do Ensino Fundamental I e para o Ensino Fundamental II com regime de cinco anos, que compreende alunos de $6^{\circ}$ a $9^{\circ}$ ano $\left(5^{\mathrm{a}}\right.$ a $8^{a}$ série), pois a obra literária é voltada para o público juvenil e o conteúdo trabalhado faz parte desse nível de ensino, porém, cabe ressaltar, que as propostas podem ser aplicadas em outros níveis de ensino caso sejam adaptadas e adequadas para o nível escolhido, cabendo ao professor esse trabalho.

As propostas foram divididas em três blocos, sendo que a proposta do Bloco 1 é uma avaliação diagnóstica dos conhecimentos prévios dos alunos sobre a pesquisa científica. No Bloco 2 propomos a realização da leitura da obra de literatura juvenil $O$ caso da borboleta Atíria. No Bloco 3 propomos o debate das teorias epistemológicas da construção da ciência dos empiristas, de Kuhn, Popper e Feyerabend, mostrando que não há uma única forma de se fazer ciência e no Bloco 4 apresentamos atividades práticas de fixação, onde o aluno será colocado em um cenário para que atuem como investigadores, sendo que o cenário será baseado na história do livro.Consideramos como base o tempo de cinquenta minutos por aula. 
Aulas 1 e 2

-Objetivos específicos: Realização de uma avaliação diagnóstica com os alunos para saber o que os alunos já sabem, para ponderar o tempo a ser desprendido em cada assunto e sensibilizá-los acerca do tema.

-Conteúdos conceituais: Os conteúdos serão acessados conforme o desempenho dos alunos durante a avaliação diagnóstica.

-Conteúdos procedimentais: Levantamento de ideias.

-Conteúdos atitudinais: Saber respeitar e ouvir a opinião dos colegas e saber esperar a vez de falar.

-Roteiro da aula: Iniciar apresentando o conteúdo por meio de perguntas, isto é, que levem os alunos a desencadearem novas perguntas, levantando suas próprias dúvidas e compartilhando-as com os colegas. Conforme as perguntas forem surgindo, o professor poderá ir anotando na lousa ou convidar um aluno para fazer esse registro. Esse registro na lousa é importante para que os alunos não percam as ideias já ditas e para que eles possam transcrever em seus cadernos.

Nessa discussão poderão ser abordadas e debatidas questões como: O que é um cientista?; O que ele faz?; Qual seu ambiente de trabalho?; Qual a importância da ciência no dia-a-dia das pessoas?; Diferenças entre o fazer científico e outras formas de investigações (ex: dedução); Como fazer uma pesquisa científica?, entre outros pontos. Tais discussões elucidarão dúvidas sobre o assunto e proporcionarão aos professores uma melhor visualização do conhecimento prévio dos alunos e possibilitar nas aulas seguintes uma leitura diferenciada da obra literária, ou seja, o olhar dos alunos leitores será mais aguçado e direcionado para esse fim.

-Recursos didáticos: Giz e lousa. O professor poderá, caso desejar, utilizar um computador com projetor e um programa de digitação, podendo convidar os alunos para que digitem suas perguntas e colocações.

-Tempo: 50 a 100 minutos (1 ou 2 aulas) de discussão para a avaliação diagnóstica.

-Modalidade didática: Discussão em grupo, com direcionamento do professor.

-Pré-requisitos: Para esta primeira aula não existem pré-requisitos imprescindíveis.

-Formas de avaliação: Observação do comportamento dos alunos durante o debate, 
assim como as colocações e o engajamento deles durante a atividade.

Cabe ressaltar que a partir da análise dos resultados dessa aula, o professor mediador das discussões poderá escolher o tempo de duração que aplicará na abordagem dada aos pontos que serão discutidos nessa proposta.

Aula 3 e 4

-Objetivos específicos: Desmistificar a ideia de que os cientistas são iguais acabando com possíveis estereótipos e debater alguns métodos de pesquisa.

-Conteúdos conceituais: Serão discutidos os estereótipos de cientistas e de seu ambiente de trabalho e as diferentes formas de se fazer ciência, abordando algumas profissões distintas que se utilizam de recursos científicos.

-Conteúdos atitudinais: Mudança da visão ou afirmação de ideias acerca do cientista e de sua postura frente a uma questão.

-Conteúdos procedimentais: Exercitar os hábitos de leitura de imagens e textos, escrita e transcrição dos pensamentos para o caderno e resolução de situações problema.

-Roteiro da aula: Com algumas perguntas selecionadas da aula anterior, relembrar os alunos das mesmas e convidá-los a responder a essas perguntas. Após essa primeira parte, o professor irá convidar os alunos a observarem algumas imagens e pedir para que escolham entre as imagens, a (as) imagem (ns) que julgarem ser a mais adequada com a ideia de cientista que eles possuem. Também serão apresentadas imagens de ambientes de trabalho diferentes conforme a função do cientista. Após a discussão será proposto aos alunos um problema de pesquisa que esteja próximo de sua realidade. O professor poderá escolher o cenário de sua escolha, como o problema exemplo a seguir:

"Todos os alunos da escola passaram mal no dia anterior depois de irem à aula".

Os alunos deverão explicar se colocando na posição de um cientista (conforme sua ideia de cientista) o que pode ter acontecido e quais métodos eles utilizariam para resolver essa questão. Esse cenário deverá ser anotado e resolvido individualmente pelos alunos como atividade escrita. $\mathrm{O}$ professor mediador dará um tempo para a realização da atividade e posteriormente fará a leitura delas para que sejam debatidas.

-Recursos didáticos: Giz, lousa e imagens. As imagens podem ser impressas ou apresentadas com o uso de um retroprojetor ou por um computador com projetor.

-Tempo: 50 minutos de leitura de imagens e de discussão sobre as mesmas e mais 50 
minutos para a leitura compartilhada das atividades propostas.

-Modalidade didática: Debate e aula expositiva.

-Pré-requisitos: Não há.

-Forma de avaliação: Observação dos alunos durante a discussão, avaliando suas reações e inquietações. Também haverá a atividade escrita como recurso material para ser avaliado. Se desejar, o professor poderá aplicar uma avaliação com questões sobre o conteúdo trabalhado para encerrar este bloco.

-Material de apoio para a aula: Imagens.

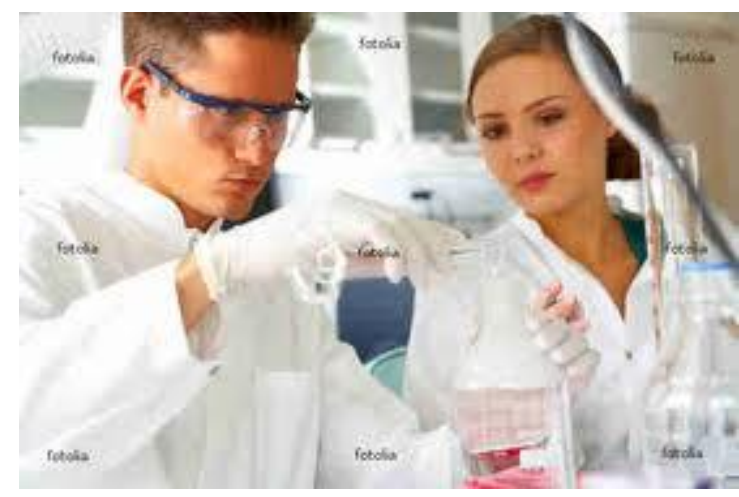

Figura 3 Cientistas trabalhando

Fonte:http://blog.daum.net/_blog/BlogTypeView.do?blogid=0 YYFH\&articleno=422\& categoryId $=3 \&$ regdt $=201212071803$ 00\#ajax_history_home

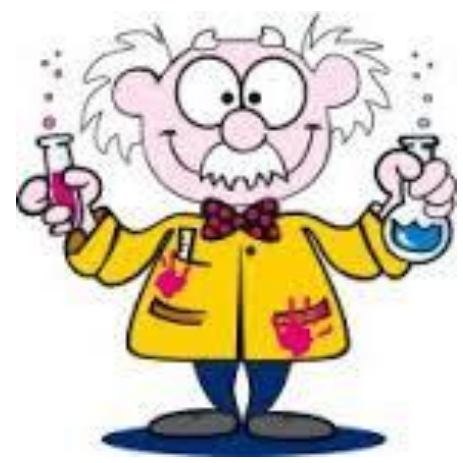

Figura 4 Estereótipo do cientista

Fonte:http://cctecaplanetario.blogspot.com.br/2011/11/projeto -jovem-cientista-reuniao-neste.html 


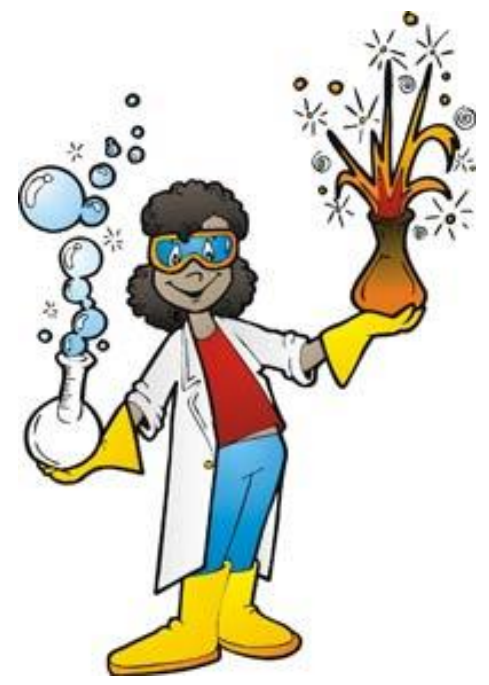

Figura 5 Estereótipo de uma cientista

Fonte: http://ceticismo.net/2011/11/04/faca-do-seu-filho-umpequeno-cientista-me-agradeca-depois/

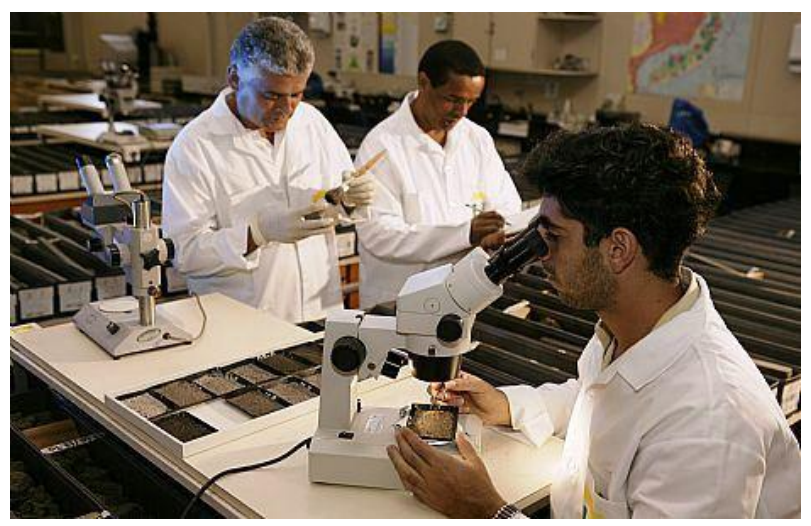

Figura 6 Ambiente de trabalho de cientistas

Fonte:http://commons.wikimedia.org/wiki/File:Cientistas_tra balhando_no_CENPES_-_UFRJ_2.jpg

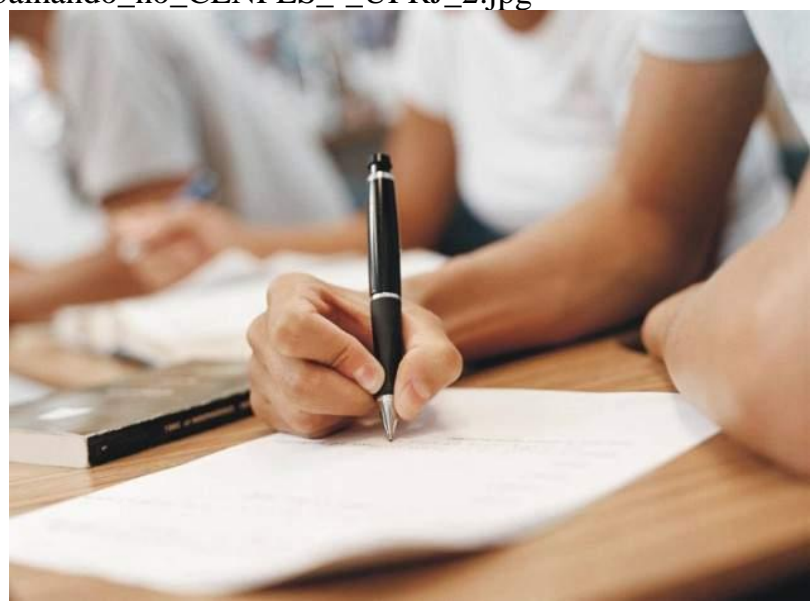

Figura 7 Produção científica escrita

Fonte: http://inovabrasil.blogspot.com.br/2007/05/arte-deredigir-um-trabalho-cientfico.html 


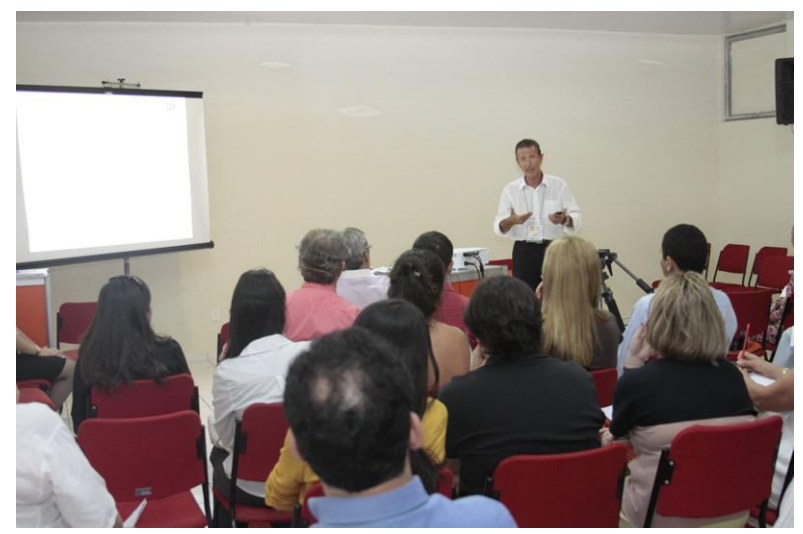

Figura 8 Divulgação do trabalho científico Fonte: http://www.cbpabp.org.br/hotsite/curso-comoescrever-e-publicar-um-trabalho-cientifico/

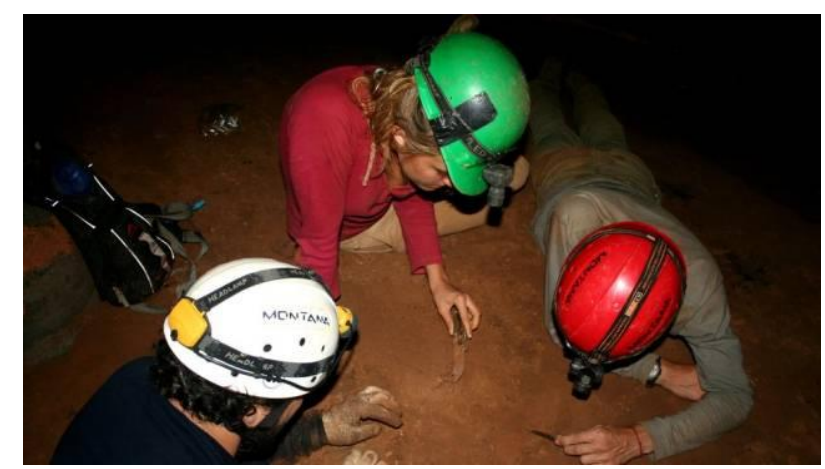

Figura 9 Trabalho de campo - escavações Fonte:http://extra.globo.com/noticias/educacao/vida-decalouro/onde-google-nao-tem-vez-jovens-universitarios-seenvolvem-em-pesquisas-serias-atraves-da-iniciacaocientifica-3992028.html

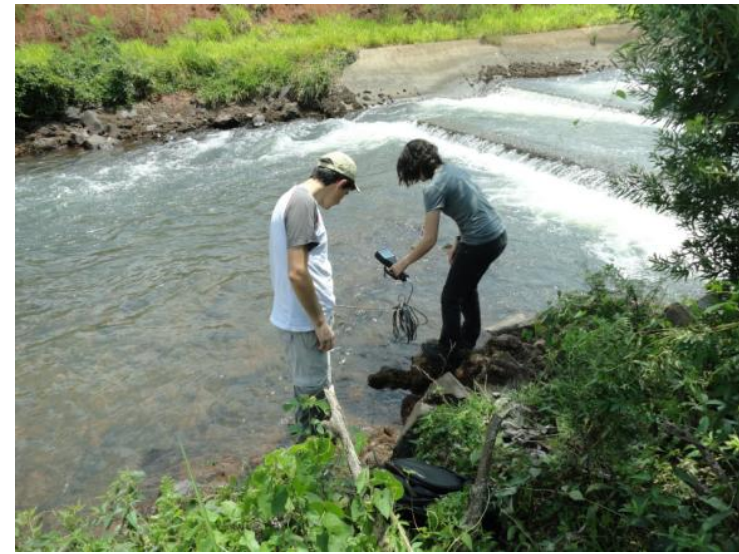

Figura 10 Análise de ambiente natural Fonte:http://unila.edu.br/noticias/pesquisacient $\%$ C3\%ADfica-0 


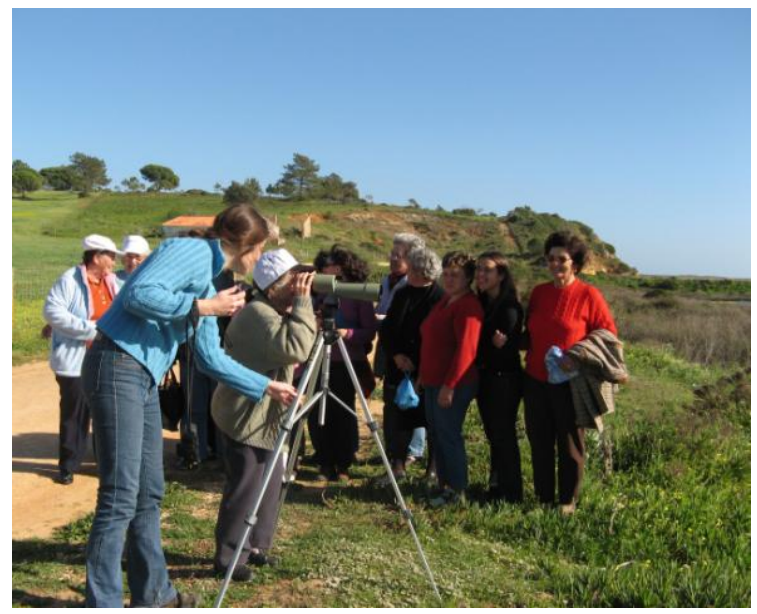

Figura 11 Observação do ambiente Fonte:http://www.arocha.org/pt-pt/somos/que/vol/ cienproj.html

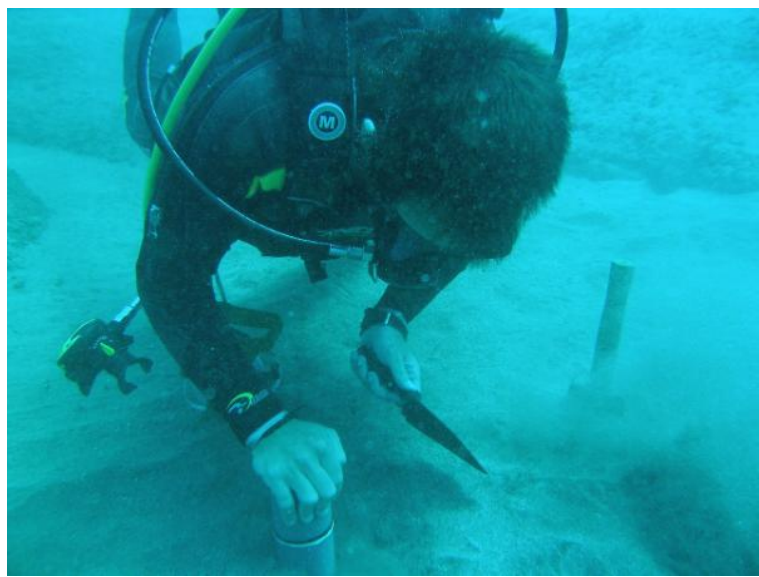

Figura 12 Pesquisa em ambiente aquático Fonte:http://www.nasal.uac.pt/pagina/entrada/cientifico

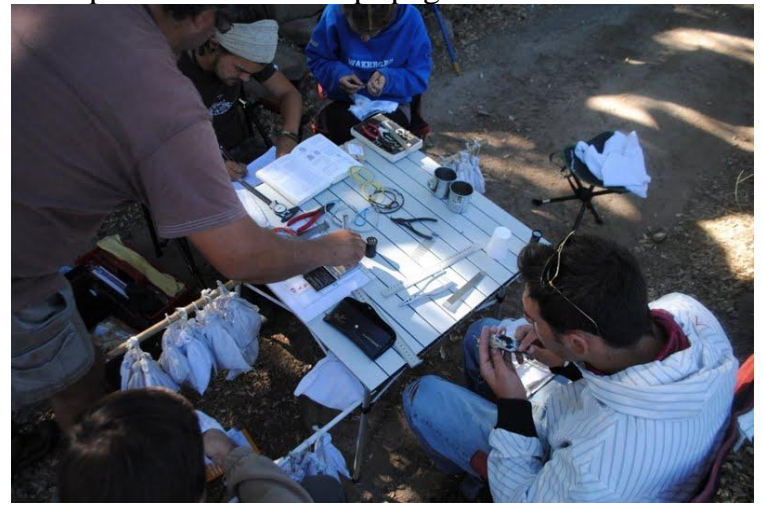

Figura 13 Organização de materiais coletados em campo Fonte:http://atnatureza.blogspot.com.br/2012_04_01_archive. html 


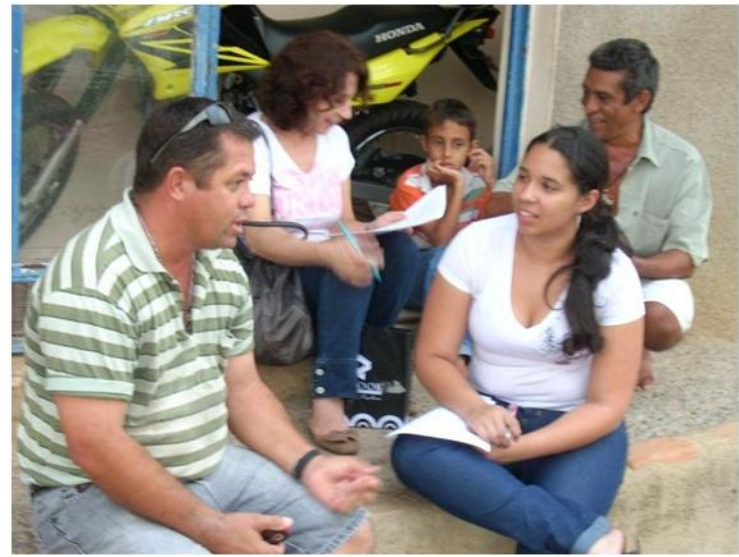

Figura 14 Entrevista para pesquisa

Fonte:http://www.fflch.usp.br/dl/indl/Extra/Projeto_Iphan_U SP.htm

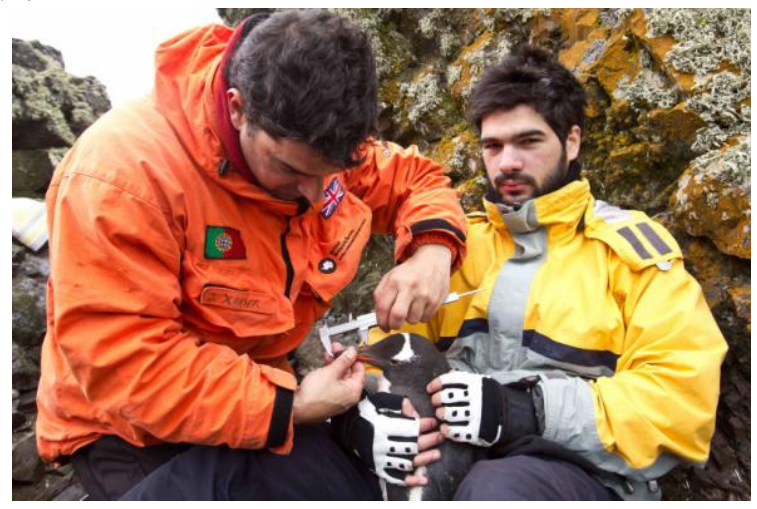

Figura 15 Pesquisa com animais

Fonte:http://cientistapolarjxavier.blogspot.com.br/2012_01_0 1_archive.html

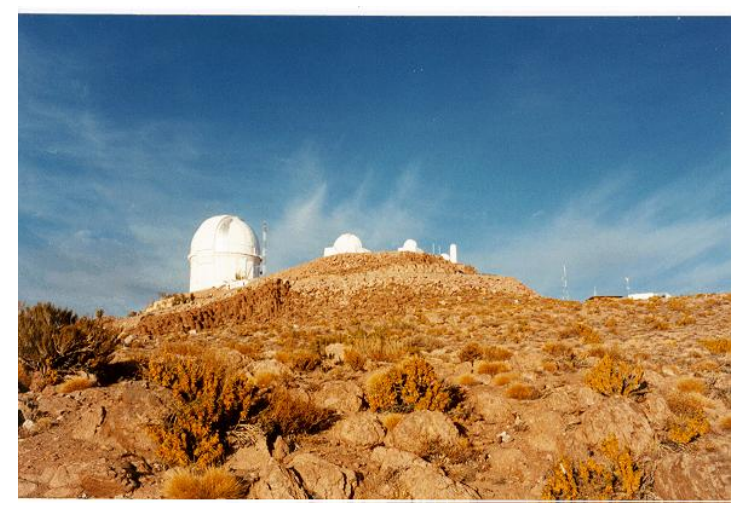

Figura 16 Local de pesquisas astronômicas Fonte:http://www.cdcc.usp.br/cda/ser-astronomo/node3.htm 


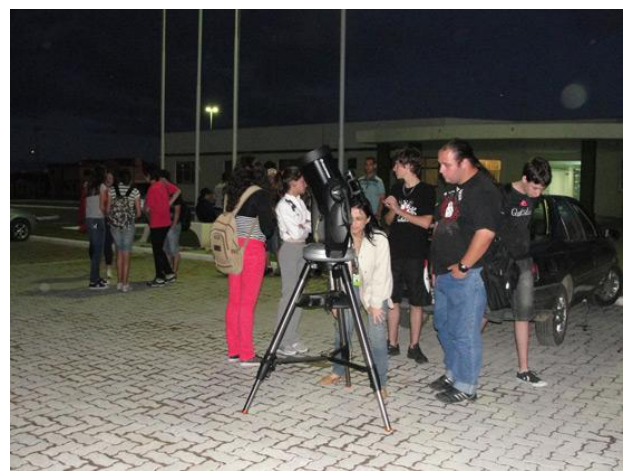

Fonte:http://portal.mec.gov.br/index.php?option=com_conten t\&view=article \&id=16632:telescopio-aproxima-astronomiae-fisica-de-estudantes- gauchos $\&$ catid $=209 \&$ Itemid $=86$

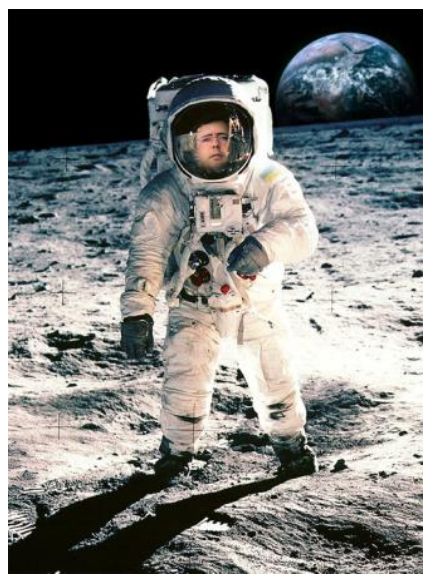

Figura 17 Viagens astronônicas para pesquisa Fonte:http://www.elitepoa.com.br/professores_daniel_fonsec a.asp

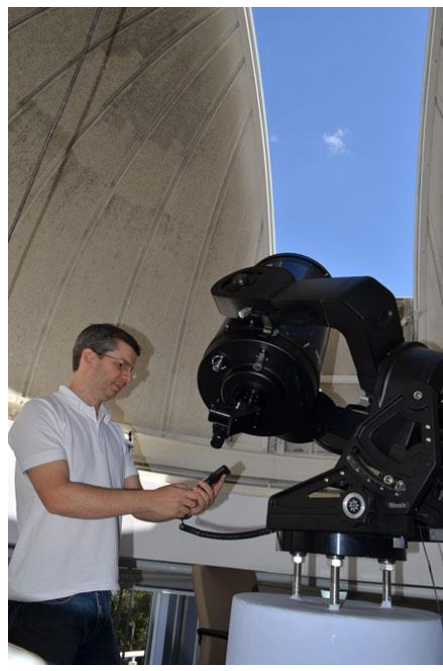

Figura 18 Observações para estudo

Fonte:http://www.univap.br/dialogo_informativo/2013/ed185 _sem11_18fev.html 


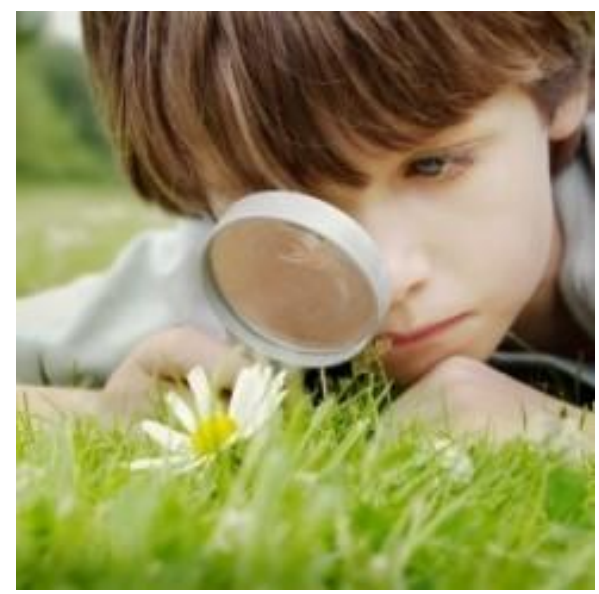

Figura 19 Observações do meio ambiente Fonte:http://www.maiseducativa.com/2012/06/14/ja-falasuniversites/

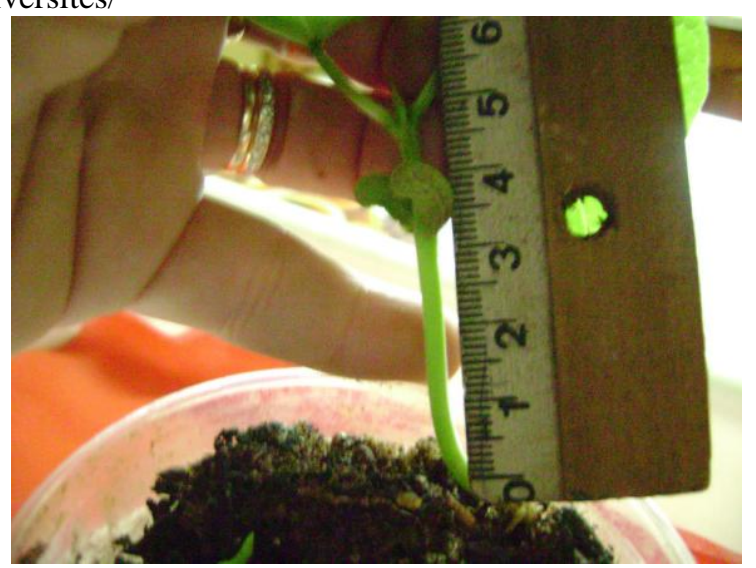

Figura 20 Realização e acompanhamento de pesquisa Fonte:http://pequenocientistacolaborador.blogspot.com.br/20 11/06/atividade-2-etapa-3-observando-e.html

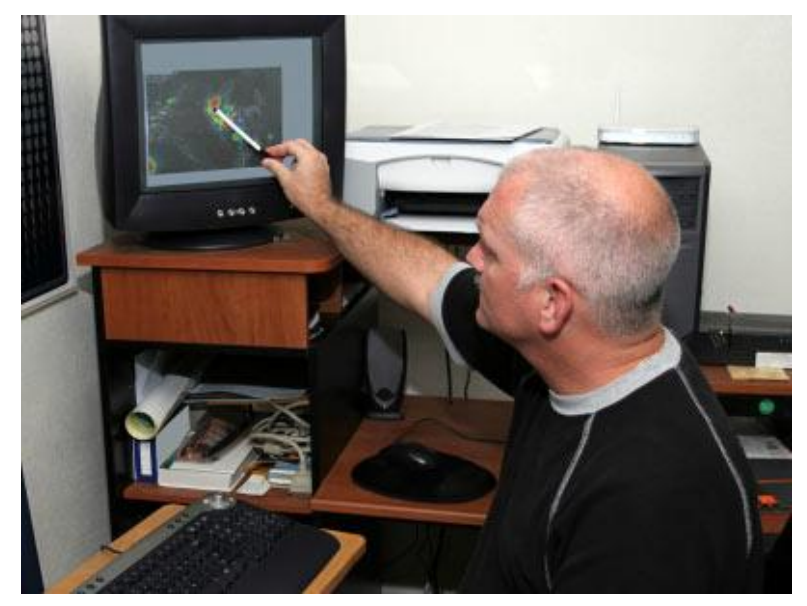

Figura 21 Análise de dados

Fonte:http://ciencia.hsw.uol.com.br/meteorologia3.htm 
Poderão ser debatidas com os alunos as funções de diferentes profissionais como, médicos, farmacêuticos, pesquisadores (biólogos, astrônomos, geólogos, matemáticos, físicos, químicos, astrônomos, etc.) e poderá ser questionado se suas funções pertencem ao ramo da ciência. Além disso, explorar os diferentes ambientes de trabalho e de realização de pesquisa conforme a área, como diferentes ambientes naturais (terrestre e aquático), laboratório e por fim, debater as diferentes formas de pesquisa, seja ela feita por meio de questionários, debates, análise de dados ambientais, etc.

Nesse bloco buscamos o desenvolvimento das seguintes competências e habilidades dos alunos:

$\checkmark$ Exercitar o poder de argumentação.

$\checkmark$ Organizar, relacionar, selecionar e interpretar dados e informações, representados de formas variadas para que situações-problema sejam solucionadas.

$\checkmark$ Relacionar informações e conhecimentos disponíveis em situações reais para criar argumentações consistentes.

$\checkmark$ Associar figuras ou desenhos de cientistas e laboratórios com modelos representativos da realidade.

$\checkmark$ Construir e aplicar o conceito de cientista e investigação científica.

$\checkmark$ Ler, interpretar e fazer o uso de diferentes linguagens como fotos e figuras.

$\checkmark$ Fazer anotações e esperar sua vez de falar.

\subsubsection{Bloco 2: Leitura compartilhada}

Aula 1 a 4

-Objetivos específicos: Leitura da obra de literatura juvenil $O$ caso da borboleta Atíria

-Conteúdos conceituais: Entender como funciona uma investigação em torno de um crime presente em um romance policial.

-Conteúdos atitudinais: Respeitar as regras estipuladas para a leitura, manter silêncio quando os colegas estiverem lendo, pró-atividade para a leitura e gosto pela leitura de obras literárias.

-Conteúdos procedimentais: Abstração para se colocar no enredo da obra e visualização das cenas, atenção durante a leitura, exercício do hábito de leitura de textos, 
estimular e aprimoramento da escrita por meio das transcrições dos fatos para o caderno.

-Roteiro da aula: O professor poderá realizar essa aula em um ambiente extraclasse, como o jardim da escola, caso haja algum. Acreditamos que a proposta de uma aula no jardim seja interessante porque a história do livro se passa em um bosque, portanto os sons naturais dos animais presentes no ambiente do jardim escolar servirão de recurso para situarem melhor os alunos no contexto, estimulando sua imaginação. Ao chegar ao local, os alunos devem se colocar de forma a ficarem confortáveis, pois para a leitura isso é essencial. Pensando nisso, o professor pode utilizar as cadeiras da sala pedindo para que cada aluno traga a sua ou espalhar colchonetes, como aqueles utilizados em aulas de educação física, caso haja.

Quando o ambiente estiver favorável para a leitura, o professor fará a apresentação da obra e convidará os alunos para a realização da leitura de forma compartilhada. A leitura compreenderá oito capítulos cujos títulos são: “Atíria; A folha falante; O Príncipe Grilo, Caligo e Papílio; Vanessa Atalanta; Aventura; A nuvem negra; O galho mágico; Mistério e O fantasma" que estão contidos entre as páginas 5 e 36 (versão utilizada na pesquisa). Caso a quantidade de livros não seja suficiente para todos os alunos, pode ser feita a realização de cópias desses capítulos ou uma leitura compartilhada em que o livro seja lido por alunos que se apresentarem como leitores voluntários.

O professor poderá pedir para os alunos que sejam feitos registros que julgarem importantes para o entendimento da história, com a finalidade de poderem recorrer às anotações quando necessitarem. Essas anotações individuais também serão importantes para que os alunos tenham mais facilidade na realização das atividades que farão nas aulas seguintes.

-Tempo: 20 minutos para a organização do ambiente de leitura e o restante do tempo para a leitura. Como serão necessárias no mínimo quatro aulas para a leitura dos capítulos, propomos que sejam feitas duas paradas de 5 minutos para que os alunos possam ir ao banheiro e beberem água, podendo assim relaxar o corpo.

-Recursos didáticos: Livro literário de romance policial $O$ caso da borboleta Atíria.

-Modalidade didática: Leitura.

-Pré-requisitos: Conhecimentos de leitura

-Forma de avaliação: Pó-atividade e interesse para a realização da leitura e o comportamento dos alunos durante a atividade. 
-Objetivos específicos: Entender o que os alunos entendem de etapas de investigação e se conseguem fazer associações entre o livro e o fazer científico.

-Conteúdos conceituais: Os conteúdos serão acessados conforme os conhecimentos prévios dos alunos e os pontos presentes no livro de literatura. Caso seja necessário, explicar o conceito de analogia.

-Conteúdos atitudinais: Expressar e ouvir opiniões sabendo esperar a vez de falar.

-Conteúdos procedimentais: Levantamento de ideias e realização de atividades.

-Roteiro da aula: Iniciar relembrando a história do romance policial juntamente com os alunos por meio de questionamentos. Também pode ser utilizada uma palavra cruzada (exemplo disponível no material de apoio dessa aula) para que os alunos relembrem a história. Tal atividade é baseada em quinze perguntas que ao serem respondidas corretamente, levam o seu realizador ao encontro do nome principal, que fica na única linha vertical da atividade.

Propomos essa atividade por se tratar de uma tarefa "cognitivamente desafiadora", ou seja, são atividades mentais que testam os conhecimentos armazenados na memória do seu realizador, pois ele terá que recorrer à memória, buscando fatos como nomes, palavras, situações e informações diversas sobre o conteúdo do livro.

Posteriormente, dependendo da faixa etária dos alunos, o professor poderá pedir para que façam um desenho do cenário mais marcante da história. A proposta de desenho pode ser mais interessante na fase inicial do Fundamental II, ou seja, no $6^{\circ}$ e $7^{\circ}$ ano.

Como atividade principal, será proposto aos alunos que registrem a partir do que entenderam da história e com base apenas em seus conhecimentos prévios, o que eles entendem por fatos, pistas e hipóteses e em que situações eles visualizaram tais pontos na história. Além disso, deverá constar nessa atividade o que para eles foi o ponto mais importante apresentado até o momento para que o mistério seja desvendado. Também deve ser pedido aos alunos que registrem suas opiniões sobre qual (is) seria o personagem (ns) que eles julgassem ser (em) o (s) assassino (s).

Para finalizar, pedir aos alunos que escolham um personagem que possa ser comparado analogamente a um cientista e explicar o porquê de sua escolha. Essa atividade deve ser aplicada tendo como ponto de partida apenas a leitura do livro, ou seja, sem nenhuma abordagem do assunto previamente, tendo como base apenas os conhecimentos prévios de cada aluno.

-Recursos didáticos: Giz, lousa, livro de literatura, folhas de sulfite para desenhos e 
almaço para o registro das atividades.

-Tempo: 10 minutos para relembrar a história do livro e 50 minutos de registros.

-Modalidade didática: Aula expositiva, colocações com direcionamento do professor e escrita, onde os alunos apresentam suas opiniões por meio de registros.

-Pré-requisitos: Leitura prévia do livro $O$ caso da borboleta Atíria, entender o conceito de analogia.

-Formas de avaliação: Participação, desenho e atividade escrita.

A leitura do livro pode ser feita de uma vez só, ao invés de ser feita em partes como proposto no bloco, pois o livro é de leitura rápida. Caso o tempo de aula seja curto para a abordagem dessa temática e o professor prefira, os alunos podem ler o livro em casa deixando para fazerem em sala apenas as discussões e atividades escritas. A proposta de leitura na escola junto com o professor é para que esta seja garantida, assim o professor poderá também avaliar a atividade. Além do mais, na leitura compartilhada os alunos exercitam sua atuação em público com a leitura em voz alta.

Caso o professor deseje, pode ser feita a leitura de trechos do livro com o objetivo de otimizar o tempo. Outra opção para o uso do livro seria o professor fazer sua apresentação e posteriormente fazer uma contagem de história sintetizada, ou seja, o professor irá contar aos alunos os pontos principais da história. Caso deseje fazer essa proposta, o professor poderá recorrer ao tópico "Estabelecendo relações entre a Pesquisa científica e a investigação do detetive" desse trabalho em que foi feito o levantamento das sequências de acontecimentos da trama.

Também fica como opção ao professor aplicar o Bloco 1 antes da leitura do livro pois o debate acerca do cientista poderá ajudar no momento em que os alunos fizerem a analogia entre o cientista e o personagem da história, assim como, os ajudarão a explicitar melhor o que entendem por fatos e hipóteses, caso esses termos apareçam nas discussões do Bloco 1.

- Material de apoio: Palavra cruzada 


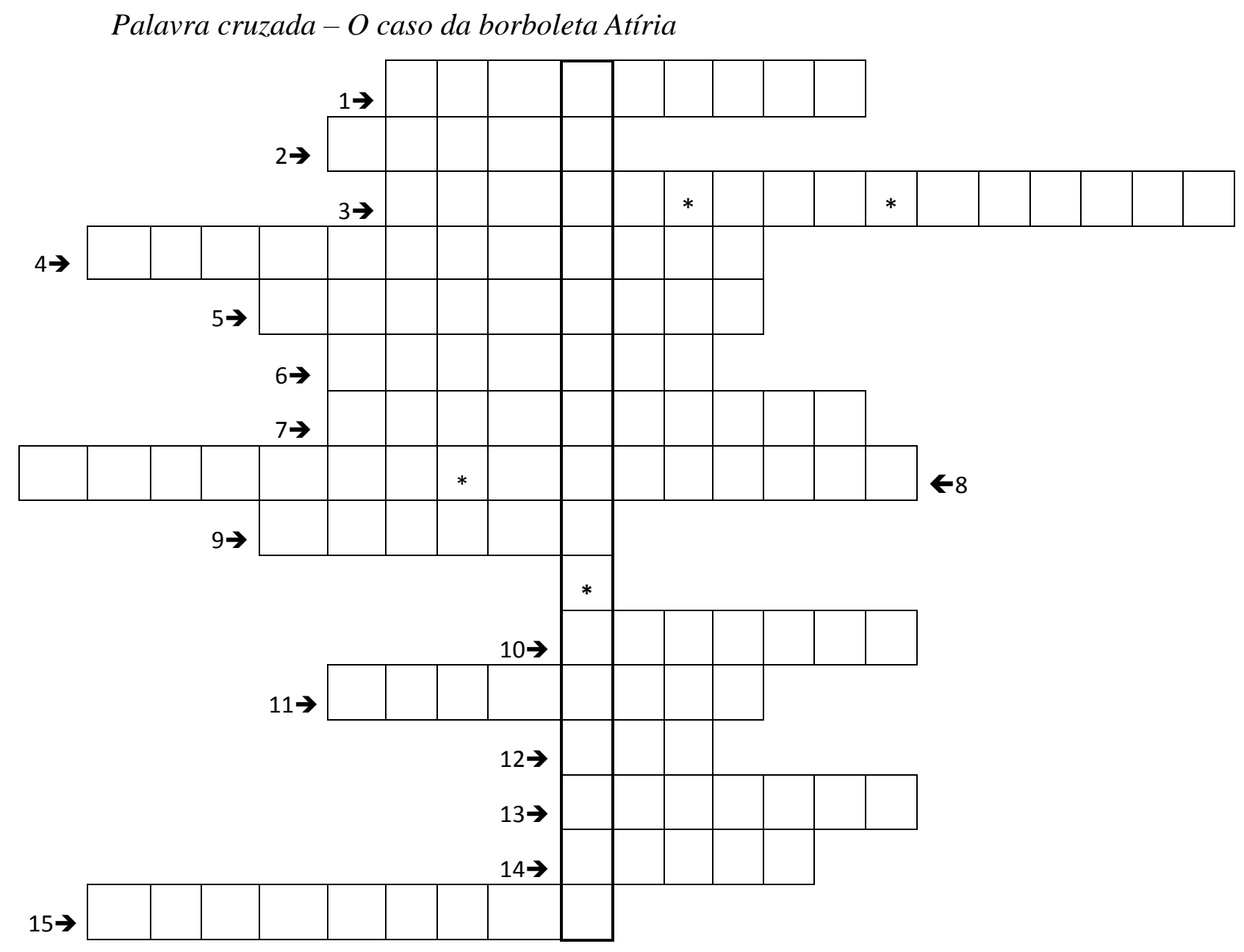

1. A personagem principal chamada Atíria é uma noturna que pode ser encontrada nos bosques brasileiros.

2. O príncipe da floresta.

3. Local onde a noiva do príncipe foi encontrada morta.

4. O ser vivo que adotou Atíria era uma que mede cerca de sete centímetros e é aparentada com a cigarra.

5. Qual é o nome da noiva do príncipe que foi assassinada?

6. Qual é o nome do detetive do reino?

7. A borboleta estrangeira foi encontrada morta, envenenada por um ramo de

8. Nome da borboleta estrangeira que veio da Inglaterra.

9. A borboleta estrangeira foi encontrada agonizando e murmurou a palavra 
10. Em uma larvas de abelhas estavam sendo mortas por duas borboletas que tinham coloração parecida com a das abelhas.

11. Surgiu um boato no bosque que nas noites de lua aparecia um no alto do morro. O detetive investigou e descobriu que era um inseto.

12. O detetive escuta a conversa dos dois assassinos e descobre que um dos cúmplices é um ser vivo que nasceu e vive nas trevas porque seu sistema nervoso não suporta

13. Língua universal dos insetos.

14. Local onde Atíria foi presa ao ser sequestrada.

15. Alguns insetos utilizam de artifícios para se proteger de possíveis predadores e no caso da assassina para se passar por coruja. Qual é o nome desse recurso?

Quadro de respostas:

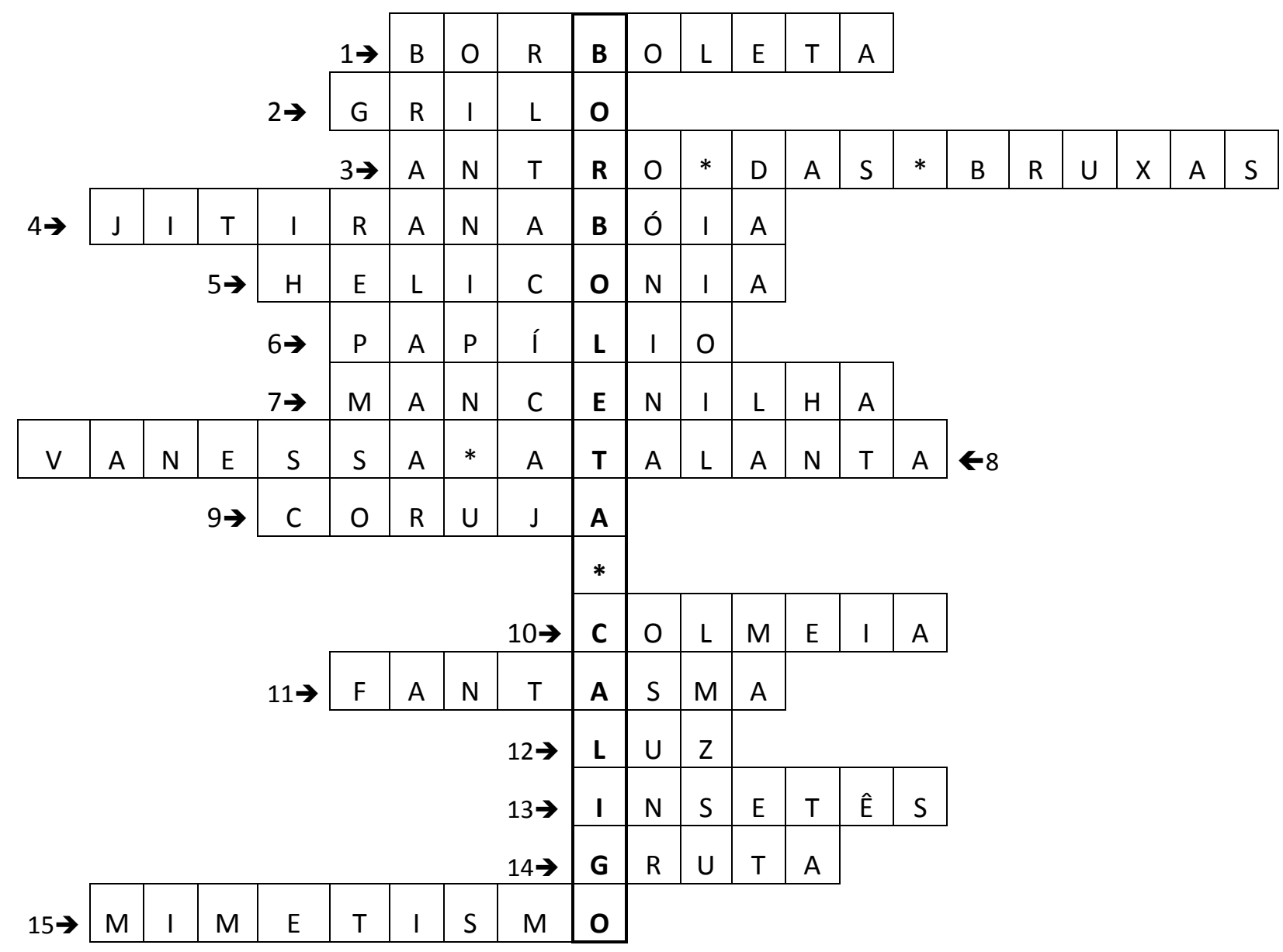


Nesse bloco buscamos o desenvolvimento das seguintes competências e habilidades dos alunos:

$\checkmark$ Estimular a capacidade de escutar e supor, possibilitando o domínio dos códigos que expressam a defesa e a construção dos argumentos.

$\checkmark$ Ler atribuindo significado para a oralidade.

$\checkmark$ Exercitar a escrita assumindo sua autoria.

$\checkmark$ Organizar, relacionar, selecionar e interpretar dados e informações.

$\checkmark$ Relacionar informações e conhecimentos disponíveis em situações reais para criar argumentações consistentes.

$\checkmark$ Fazer anotações e sínteses.

\subsubsection{Bloco 3: Teorias epistemológicas da construção da ciência}

Aula 1 a 3

-Objetivos específicos: Apresentar e debater algumas visões acerca da construção da ciência, baseadas nas literaturas de Popper, Kuhn, Feyerabend e nas visões empiristas.

-Conteúdos conceituais: Entender as ideias de Popper, Kuhn, Feyerabend e as visões empiristas sobre a construção da ciência.

-Conteúdos atitudinais: Atenção, respeito, participação e reformulação de concepções.

-Conteúdos procedimentais: Levantamento e registro de ideias e participação.

-Roteiro da aula: A princípio seria feita uma aula expositiva apoiada por debates onde os alunos expõem suas dúvidas e entendimentos sobre o assunto. Esse debate pode ser intermediado por meio de questões concebidas pelo professor. No final dessa aula, o professor poderá aplicar um questionário com o objetivo de avaliar o que cada aluno entendeu e solucionar as possíveis dúvidas. Posteriormente o professor poderá responder o questionário juntamente com os alunos, fazendo uma revisão. Como material de apoio para as aulas, fizemos um texto que aborda de forma clara e sucinta as ideias de Popper, Kuhn, Feyerabend e as visões empiristas para o professor e outro texto destinado para os alunos, escrito de forma mais simplificada. Caso o professor queira, poderá fazer uma pesquisa complementar para a aula.

Após a realização dessas aulas, o professor poderá aplicar o Bloco 2 e debater com os alunos após a leitura do livro $O$ caso da borboleta Atíria em que situações da história as 
visões filosófica aqui trabalhadas se enquadram, fazendo assim, um trabalho mais aprimorado. A intenção é que os alunos percebam que há várias abordagens e que não necessariamente uma delas tenha que ser a única compatível com a forma de fazer ciência apresentada na obra de literatura. Essa proposta vai de encontro com a ideia de Chalmers (1993, p. 182), de que é necessário o estudo de diversas formas de conhecimento para que se entendam seus objetivos e métodos e acrescenta que é prejudicial à sociedade ter a errônea ideia de que exista um método científico universal.

-Recursos didáticos: giz e lousa. O material de apoio pode ser impresso e distribuído para que os alunos possam fazer anotações e acompanhar a leitura.

-Tempo: 100 minutos de leitura e debate e 50 minutos de resolução de questionário.

-Modalidade didática: Aula teórica.

-Pré-requisitos: Não há.

-Formas de avaliação: Averiguação do caderno ou folhas de anotações, comportamento e engajamento no debate e questionário.

-Material de apoio para a aula:

\section{TEXTO PARA O PROFESSOR}

Teorias epistemológicas sobre a investigação científica

\section{Empirismo}

Segundo Oswaldo Porchat (2007, p. 17) é difícil explicar claramente o que é o empirismo, haja vista que muitos filósofos que se apresentam como empiristas propõem doutrinas bem diversas uma das outras, mesmo que tais doutrinas possuam características em comum.

Sua concepção a respeito do empirismo foi expressa simplificadamente da seguinte forma:

Usarei o termo "empirismo" para caracterizar toda doutrina filosófica ou teoria do conhecimento segundo a qual todo conhecimento humano deriva, direta ou indiretamente, da experiência, implicando também que todas as nossas ideias ou conceitos tem primordialmente sua origem na experiência (PORCHAT, 2007, p.17).

Dentre os filósofos empiristas, destacam-se John Locke, Thomas Hobbes, George Berkeley, David Hume, Thomás de Aquino, entre outros. 
O termo empirismo tem a sua origem no grego empeiria, que significa experiência sensorial (BAZARIAN, 1994, p. 99). Esta corrente é considerada uma doutrina relativa à natureza do conhecimento (LALANDE, 1996). Restringiu-se o termo empirismo à filosofia clássica moderna, contrastando-se o empirismo inglês (Francis Bacon, Hobbes, Locke, Berkeley, Hume) com o racionalismo continental (Descartes, Malebranche, Spinoza, Leibniz, Wolff).

Conforme Porchat (2007, p.18), o empirismo britânico perdurou no século XX pelo empirismo lógico, que consiste em ter a experiência como forma de verificação ou confirmação direta ou indireta de todo conhecimento de matéria. O empirismo vem tentar responder à questão sobre a origem do conhecimento.

Segundo Hessen (2003, p. 54) “À tese do racionalismo, segundo a qual a verdadeira fonte do conhecimento é o pensamento, a razão, o empirismo contrapõe a antítese, dizendo que a única fonte do conhecimento humano é a experiência”. Os empiristas defendem que a experiência é a base do conhecimento científico, ou seja, adquire-se conhecimento através da percepção do mundo externo ou através do exercício da nossa mente ao reter a realidade exterior e ao modificá-la internamente. O empirismo tem, portanto, um caráter individualista, uma vez que a percepção do meio é diferente de um individuo para o outro.

O empirismo parte dos fatos concretos e para justificar seu ponto de vista, o empirismo aponta para o desenvolvimento do pensamento e do conhecimento humano, comprovando a grande importância da experiência para que o conhecimento se desenvolva. Hessen (2003, p. 55) diz que, com base nessas percepções, o pensamento vai aos poucos formando representações e conceitos gerais, que se desenvolvem organicamente a partir da experiência. Portanto, seria inútil procurar por conceitos que já estivessem prontos no espírito ou que se formassem independentemente da experiência, sendo assim, a experiência aparece como a única fonte de conhecimento.

O empirismo, enquanto corrente de pensamento, postula, ainda, certos traços capitais que podem ser extraídos do Tratado do entendimento humano de John Locke (bem como de textos de seus seguidores: Adam Smith e David Hume. Primeiro, rejeita qualquer princípio ou conhecimento inato que seria válido sem qualquer verificação. Segundo, rejeita qualquer coisa supra-sensível, ou seja, qualquer realidade que não pode ser controlada ou verificada. Terceiro, atribui especial ênfase a órgãos (ou instrumentos) de verificação e comprovação. Por fim, o último traço capital admite o caráter limitado e imperfeito dos instrumentos que o homem dispõe para verificar e comprovar a verdade. 
Em contraposição às ideias inatas dos racionalistas, os empiristas partilham da ideia de tábua rasa. Tal ideia concebe que a mente humana é tal como uma folha em branco em que os conhecimentos são escritos. Assim, uma criança, por exemplo, inicialmente nada conhece, sendo sua mente ainda uma folha em branco, uma tábua rasa, aguardando informações, em seguida ela experimenta suas cercanias através de seus sentidos, a partir de então ele passa a conhecer. Assim, os elementos adquiridos pela experiência são a verdade em si, ou seja, a experimentação sozinha é capaz de fornecer a verdade (HESSEN, 2003, p. 41).

"Para os empiristas modernos a mente é como que uma espécie de receptáculo no qual se gravam as 'impressões' do mundo externo. Apesar da existência de diferentes abordagens sobre o mesmo assunto, há algo comum a todos esses pensadores, que é a tendência de proporcionar uma explicação genética do conhecimento e a usar termos como 'sensação', ‘impressão', ‘ideia’” (PORTUGAL, 2002, p. 10).

Conforme Hessen (2003), as ciências naturais são as que possuem maior proximidade com a doutrina empirista, uma vez que elas se apoiam na experiência para construir seus conhecimentos. Se, em sua maioria, os racionalistas provinham da matemática, a história do empirismo mostra que seus representantes provêm quase sempre das ciências naturais. Isso é compreensível, já que nas ciências naturais a experiência desempenha papel decisivo. O que vale é o estabelecimento de fatos por meio da observação cuidadosa. O pesquisador é completamente dependente da experiência. É muito natural que alguém, trabalhando principal ou exclusivamente de acordo com esses métodos das ciências naturais, esteja inclinado de antemão a colocar os fatores empíricos acima dos racionais. Se o epistemólogo de orientação matemática chega facilmente a encarar o pensamento como a única fonte de conhecimento, o filósofo provindo das ciências naturais estará inclinado a considerar a experiência como fonte e fundamento de todo o conhecimento humano. (HESSEN, 2003, p. 55)

De um modo geral, o empirismo defende que todas as ideias são provenientes de percepções sensoriais (visão, audição, tato, paladar, olfato) (COTRIM, 1992, p. 67). Em outras palavras, ditas por Locke "nada vem à mente sem ter passado pelos sentidos".

\section{Popper}

Karl Popper nasceu em Viena no ano de 1902 e morreu em Londres aos noventa e dois anos em 1994. Concluiu seu doutoramento em filosofia em 1928 e desde sua mocidade dedicou-se a assuntos diversos, entre eles, alguns de cunho social. Discussões sobre 
epistemologia e ciência faziam parte de seu cotidiano. Em 1934 publicou seu primeiro livro tornando-se filósofo profissional. Foi presidente de várias sociedades científicas e filosóficas, colaborador de revistas especializadas em filosofia da ciência e editor de outras (POPPER, 2008, p.15).

Popper adotou "a falseabilidade como critério para decidir se um sistema teorético pertence ou não ao campo da Ciência empírica", em oposição às ideias dos convencionalistas que não creem que as leis da natureza possam ser falseáveis por meio da observação.

Para isso, Popper explica que ele e os que compartilham de seus pensamentos buscam:

(...) efetuar descobertas novas e esperamos ser auxiliados, nesse trabalho, por um sistema científico que acaba de aparecer. Teremos, por isso, o maior interesse pelo experimento falseador...por ele ter aberto horizontes novos num mundo de experiências novas... por fornecerem argumentos novos contra as nossas mais recentes teorias (POPPER, 2008, p. 84) .

Popper rejeita o empirismo clássico e o observacionalismo-indutivista da ciência e acredita que a experiência e as observações do mundo real tem por objetivo tentar falsear uma determinada teoria em análise. Caso a teoria seja comprovadamente falsa, esta deixa de ter credibilidade, ou seja, deixa de ser aceita, abrindo espaço para uma nova teoria que consiga explicar o fenômeno em análise.

A esse respeito Karl Popper diz:

Segundo minha proposta, aquilo que caracteriza o método empírico é sua maneira de expor à falsificação, de todos os modos concebíveis, o sistema a ser submetido a prova. Seu objetivo não é o de salvar a vida de sistemas insustentáveis, mas pelo contrário, o de selecionar o que se revele, comparativamente, o melhor, expondo-os todos à mais violenta luta pela sobrevivência (POPPER, 2008, p. 44).

Conforme Aguiar (1998), Popper diz que a realização do teste de uma teoria deve ser feita de forma crítica.

O fundamental, aqui, é o problema do uso crítico da experiência. O uso positivo da experiência (verificacionismo) além dos conhecidos problemas em torno da indução, tende a minimizar as possibilidades críticas desta mesma experiência. Maximizar o criticismo empírico ou não é uma preocupação constante para Popper. Assim, a ciência empírica, para Popper, caracteriza-se pelo uso crítico da experiência. Negando este requisito, nós temos, de um lado, metodologias (ou teorias \} que utilizam a experiência de forma crítica e, de outro, teorias cuja estrutura as torna refratárias a falsificação pela experiência. A metafísica, por exemplo, nunca alegou utilizar qualquer espécie de método empírico. Entretanto, a metafísica também pode ser caracterizada através de sua não falsificabilidade. $O$ critério de falsificabilidade de Popper divide todo o sistema do nosso conhecimento em duas classes: a) a ciência empírica; b) tudo o que não é ciência empírica (AGUIAR, 1998, p. 25).

Para Karl Popper, o que define um sistema como sendo empírico ou científico será a sua comprovação pela experiência por meio da falseabilidade, critério da demarcação entre a 
ciência e a não-ciência. A esse respeito, ele diz:

Contudo, só reconhecerei um sistema como empírico ou científico se ele for passível de comprovação pela experiência. Essas considerações sugerem que deve ser tomado como critério de demarcação, não a verificabilidade, mas a falseabilidade de um sistema. Em outras palavras, não exigirei que um sistema científico seja suscetível de ser dado como válido, de uma vez por todas, em sentido positivo; exigirei, porém, que sua forma lógica seja tal que se torne possível validá-lo através de recurso a provas empíricas, em sentido negativo: deve ser possível refutar, pela experiência, um sistema científico empírico (POPPER, 2008, p.42).

É interessante notar que para Popper, o estado atual da ciência é sempre provisório, ou seja, a teoria se mantém até o momento em que ela seja falseada.

Kuhn

A princípio, Thomas Kuhn se dedicou ao estudo da física teórica. Ao participar de um curso experimental que apresentava a física para os não-cientistas, ele passou a dar uma atenção maior para a história da ciência. Nesse momento, Kuhn rompeu com seus preconceitos sobre a natureza da ciência e percebeu que os relatos tradicionais da ciência, tanto os indutivistas como os falsificacionistas, não possibilitavam uma comparação com o testemunho histórico. Com base nisso, Kuhn desenvolve uma teoria que procura ser mais coerente com a realidade histórica por ele vista (KUHN, 2007, p.9).

A ideia de Thomas Kuhn de que uma teoria científica é uma estrutura complexa, é apresentada pela primeira vez em seu livro A estrutura das revoluções científicas, publicado inicialmente em 1962. Dentre os pontos mais importantes de sua teoria, Kuhn enfatiza o caráter revolucionário do progresso científico, relatando que, na ocorrência de uma revolução, haveria o abandono de uma estrutura teórica, que seria substituída por outra incompatível. Além disso, sua teoria versa sobre as características sociológicas das comunidades científicas (CHALMERS, 1993, p. 123).

Segundo Chalmers, Kuhn e Lakatos possuem algumas características em comum, como os relatos filosóficos por eles feitos, resistirem à crítica da historia da ciência.

Kuhn relata que muitos livros têm criado uma imagem de ciência puramente persuasiva e pedagógica, assim como acontece em um folheto turístico, apresentando um conceito de ciência bastante diverso. Acrescenta ainda que esses livros trazem um conceito de ciência com implicações profundas em relação à sua natureza e desenvolvimento.

Se a ciência é a reunião de fatos, teorias e métodos reunidos nos textos atuais, então os 
cientistas são homens que, com ou sem sucesso, empenharam-se em contribuir com um ou outro elemento para esta constelação específica. O desenvolvimento torna-se o processo gradativo através do qual esses itens foram adicionados, isoladamente ou em combinação, ao estoque sempre crescente que constitui o conhecimento e a técnica científicos. E a história da ciência torna-se a disciplina que registra tanto esses aumentos sucessivos como os obstáculos que inibiram sua acumulação (KUHN, 2007, p. 20).

Kuhn questiona as dificuldades que os historiadores encontram em apresentar os avanços da ciência, muitas vezes, pautados na ideia de desenvolvimento por acumulação. Ele relata que o historiador tinha o papel de determinar quando e por quem descobriu uma teoria e ainda explicava os erros e mitos que impediram a acumulação mais ágil do moderno texto científico. Poucos ainda fazem isso, pois houve uma revolução historiográfica no estudo da ciência, onde os historiadores "procuram apresentar a integridade histórica daquela ciência, a partir de sua própria época" (KUHN, 2007, p. 21).

Em seu livro, Kuhn apresenta sua ideia de como a ciência progride, começando com a pré-ciência, a ciência normal, o surgimento da crise que acarretará na revolução, a nova ciência normal e a nova crise. Segundo Kuhn, os "paradigmas são as realizações cientificas universalmente reconhecidas que, durante algum tempo, fornece problemas e soluções modelares para uma comunidade de praticantes de uma ciência" (KUHN, 1991, p.13). O paradigma caracteriza a ciência normal que surge e se estabelece após um tipo de atividade desorganizada que tenta fundamentar ou explicar os fenômenos que está ainda em um momento irracional chamado de pré-ciência. O modelo aceito no momento pode sofrer anomalias que podem colocar em dúvida a validade do atual paradigma. Se este realmente se torna insuficiente ocorre o que Kuhn denomina de Ciência Extraordinária ou Revolucionária, que nada mais é do que a adoção de outro paradigma, isto é, muda-se a visão de mundo.

\section{Feyerabend}

A ciência possui complexas situações realistas além da impossibilidade de previsão do seu desenvolvimento, não sendo possível esperar que regras a expliquem. Com base nesse pressuposto, Feyerabend se apresenta contra metodologias fornecedoras de regras. Salienta ainda que, sendo a história tão complexa, é difícil esperar que a ciência possa ser explicada por meio de regras metodológicas simples, se pondo contra a validade universal de qualquer 
regra. Uma das formas que Feyerabend utiliza para demonstrar que todas as metodologias da ciência, propostas até então, são mal sucedidas é demonstrar as incompatibilidades que elas possuem em relação à história da física. Dentre seus argumentos, o mais convincente a respeito das metodologias, é sobre o uso de regras que são criadas com o intuito de orientar os cientistas. (CHALMERS, 1993, p. 174).

Contudo, Feyerabend comenta em um artigo que precedeu seu livro Against Method, que "vale-tudo" não deve ser levado ao pé da letra, ou seja, de forma ampla demais. No artigo ele tenta distinguir o cientista razoável do charlatão, por meio da pesquisa realizada e do ponto de vista adotado. Diferente do "pensador respeitável", o charlatão se faz por satisfeito em defender um ponto de vista em sua forma original e não está preparado para problemas em sua pesquisa, nem para corroborar de forma definitiva todas as situações que podem favorecer o oponente. Já o cientista razoável, este se atém aos detalhes, ás objeções, ao todo da investigação. Para que a investigação traga contribuições, o pesquisador deve estar familiarizado com a metodologia da ciência. Além disso, Chalmers acrescenta que "na ciência não se dá o fato de que vale-tudo sem limites”(CHALMERS, 1993, p. 176).

Feyerabend exemplifica sua ideia de incomensurabilidade apresentando pares de teorias incomensuráveis, como a mecânica clássica com a teoria da relatividade e a mecânica quântica com a mecânica clássica, mostrando que teorias incomensuráveis são aquelas cujos sentidos e interpretações dos conceitos e proposições de observações são, ou podem ser totalmente diferentes uma da outra, não sendo possível formular os conceitos básicos de uma teoria nos termos da outra. Sendo assim, a comparação entre ambas não ocorre, podendo apenas ser feita uma dedução lógica de certas consequências de uma, nos princípios da outra teoria rival. Isso significa que elas podem ser comparadas e uma das formas de realizar essa comparação é por meio da "confrontação de cada uma delas com uma série de situações observáveis e manter um registro do grau em que cada uma das teorias rivais é compatível com aquelas situações, interpretadas em seus próprios termos" (CHALMERS, 1993, p. 178).

Ao se pensar na escolha de uma teoria entre muitas, os critérios de comparação para a escolha da teoria também devem ser pensados, se tratando, segundo Feyerabend, de uma análise subjetiva. Chalmers (1993) concorda com Feyerabend ao dizer que os julgamentos e desejos individuais sejam subjetivos, ou seja, que argumentos logicamente convincentes não os podem determinar, porém, isso não significa que eles sejam imunes a argumentos racionais. Além disso, acrescenta, 


\begin{abstract}
"Estou cônscio de que as preferências dos indivíduos não são determinadas apenas pela argumentação racional e sei também que elas serão fortemente moldadas e influenciadas pelas condições materiais nas quais existe e age o indivíduo. (Uma mudança importante nas perspectivas de carreira terá provavelmente um efeito maior nas preferências de um indivíduo que um argumento racional, para dar um exemplo superficial.) Contudo, os julgamentos e desejos subjetivos dos indivíduos não são sacrossantos nem simplesmente dados. Estão abertos à crítica e à mudança pelos argumentos e pela alteração das condições materiais (CHALMERS, 1993, p.180)".
\end{abstract}

Ao falar sobre a relação entre a ciência e outras formas de conhecimento, Feyerabend relata que muitas metodologias acreditam que a ciência é o paradigma da racionalidade, julgando-a superior as outras, sem ao menos investigá-las firmemente. Exemplifica isto ao dizer que os "racionalistas críticos" não examinam a astrologia ou o marxismo de forma minuciosa como é feita com a ciência. A superioridade da ciência é algo que Feyerabend não aceita, e pautado da ideia de incomensurabilidade, ele acredita que não existe argumento decisivo a favor da ciência, frente às outras formas de conhecimento (CHALMERS, 1993).

Para Chalmers (1993, p. 182), é realmente necessário o estudo de outras formas de conhecimento para que se entendam seus objetivos e métodos. Isso é exemplificado no trecho seguinte:

\footnotetext{
"Embora seja em certa medida uma caricatura da história da filosofia, pode-se dizer que nos dois mil anos que antecederam Galileu, os filósofos argumentaram se as teorias matemáticas eram aplicáveis ao mundo físico: os platonistas dando uma resposta positiva e os aristotélicos uma resposta negativa. Galileu decidiu a questão, não produzindo um argumento filosófico decisivo, mas fazendo a coisa (CHALMERS, 1993, p.183)".
}

Chalmers (1993) acrescenta que é prejudicial à sociedade ter a errônea ideia de que exista um método científico universal, haja vista que este é normalmente empiricista ou indutivista.

Outro ponto abordado e defendido por Feyerabend é a ideia de que os seres humanos devem ser livres, com a tese de que os humanos bem desenvolvidos são produtos da individualidade. Com isso, ele incentiva que deve haver a livre escolha entre a ciência e as outras formas de conhecimento, onde cada um opte pelo que é melhor para si. Nesse contexto, Feyerabend acrescenta que o Estado deva ser ideologicamente neutro (CHALMERS, 1993, p. 184).

A esse respeito, Chalmers (1993. p.186) faz uma objeção ao dizer que "A liberdade que um indivíduo possui dependerá da posição que ocupa na estrutura social, de modo que uma análise da estrutura social é um pré-requisito para uma compreensão da liberdade do indivíduo" e Feyerabend não aborda de forma mais atenta tais coerções que operam na 
sociedade. Chalmers (1993) acrescenta que ao se almejar uma sociedade diferente, tem-se que começar a mudança a parir da sociedade contemporânea que se tem, tentando "mudá-la com os meios que se apresentam. Deste ponto de vista o ideal utópico de uma sociedade livre de Feyerabend de nada nos serve" (CHALMERS, 1993, p. 187).

Por meio das leituras sobre as visões de Feyerabend devemos entender que ele não se coloca contra nenhum método em particular. O que ele coloca é que não devemos achar que existe um método único que funciona em todos os casos, pois cada pesquisa requer um tipo de procedimento diferenciado e adequado ao propósito da pesquisa.

\section{TEXTO PARA O ALUNO}

\section{Empirismo}

Dentre os filósofos empiristas, destacam-se John Locke, Thomas Hobbes, George Berkeley, David Hume, Thomás de Aquino, entre outros.

O termo empirismo tem a sua origem no grego empeiria, que significa experiência sensorial (BAZARIAN, 1994, p. 99). Conforme Porchat (2007, p.18), o empirismo lógico consiste em ter a experiência como forma de verificação ou confirmação direta ou indireta de todo conhecimento de matéria.

Os empiristas defendem que a experiência é a base do conhecimento científico, ou seja, adquire-se conhecimento através da percepção do mundo externo ou através do exercício da nossa mente ao reter a realidade exterior e ao modificá-la internamente. O empirismo aponta para o desenvolvimento do pensamento e do conhecimento humano, comprovando a grande importância da experiência para que o conhecimento se desenvolva.

$\mathrm{O}$ empirismo, enquanto corrente de pensamento rejeita qualquer princípio ou conhecimento que seria válido sem qualquer verificação. Segundo, rejeita qualquer realidade que não pode ser controlada ou verificada. Terceiro, atribui especial ênfase a órgãos (ou instrumentos) de verificação e comprovação. Por fim, o último traço capital admite o caráter limitado e imperfeito dos instrumentos que o homem dispõe para verificar e comprovar a verdade.

Assim, os elementos adquiridos pela experiência são a verdade em si, ou seja, a experimentação sozinha é capaz de fornecer a verdade (HESSEN, 2003, p. 41).

Conforme Hessen (2003), as ciências naturais são as que possuem maior proximidade 
com a doutrina empirista, uma vez que elas se apoiam na experiência para construir seus conhecimentos. Nas ciências naturais a experiência desempenha papel decisivo. O que vale é o estabelecimento de fatos por meio da observação cuidadosa. O pesquisador é completamente dependente da experiência. Sendo assim, o filósofo provindo das ciências naturais estará inclinado a considerar a experiência como fonte e fundamento de todo o conhecimento humano (HESSEN, 2003, p. 55).

\section{Popper}

Karl Popper nasceu em Viena no ano de 1902 e morreu em Londres aos noventa e dois anos em 1994. Concluiu seu doutoramento em filosofia em 1928 e desde sua mocidade dedicou-se a assuntos diversos, entre eles, alguns de cunho social.

Popper adotou "a falseabilidade como critério para decidir se um sistema teorético pertence ou não ao campo da Ciência empírica". Ele acredita que a experiência e as observações do mundo real tem por objetivo tentar falsear uma determinada teoria em análise. Caso a teoria seja comprovadamente falsa, esta deixa de ter credibilidade, ou seja, deixa de ser aceita, abrindo espaço para uma nova teoria que consiga explicar o fenômeno em análise.

Para Karl Popper, o que define um sistema como sendo empírico ou científico será a sua comprovação pela experiência por meio da falseabilidade, critério da demarcação entre a ciência e a não-ciência. É interessante notar que para Popper, o estado atual da ciência é sempre provisório, ou seja, a teoria se mantém até o momento em que ela seja falseada (POPPER, 2008, p.42).

\section{Kuhn}

A ideia de Thomas Kuhn de que uma teoria científica é uma estrutura complexa, é apresentada pela primeira vez em seu livro A estrutura das revoluções científicas, publicado inicialmente em 1962. Dentre os pontos mais importantes de sua teoria, Kuhn enfatiza o caráter revolucionário do progresso científico, relatando que, na ocorrência de uma revolução, haveria o abandono de uma estrutura teórica aceita naquele momento, que seria substituída por outra incompatível (CHALMERS, 1993, p. 123).

Se a ciência é a reunião de fatos, teorias e métodos reunidos nos textos atuais, então os 
cientistas são homens que, com ou sem sucesso, empenharam-se em contribuir com um ou outro elemento para esta constelação específica (KUHN, 2007, p. 20).

Em seu livro, Kuhn apresenta sua ideia de como a ciência progride, começando com a pré-ciência, a ciência normal, o surgimento da crise que acarretará na revolução, a nova ciência normal e a nova crise. Segundo Kuhn, os "paradigmas são as realizações cientificas universalmente reconhecidas que, durante algum tempo, fornece problemas e soluções modelares para uma comunidade de praticantes de uma ciência" (KUHN, 1991, p.13). O paradigma caracteriza a ciência normal que surge e se estabelece após um tipo de atividade desorganizada que tenta fundamentar ou explicar os fenômenos que está ainda em um momento irracional chamado de pré-ciência. O modelo aceito no momento pode sofrer anomalias que podem colocar em dúvida a validade do atual paradigma. Se este realmente se torna insuficiente ocorre o que Kuhn denomina de Ciência Extraordinária ou Revolucionária, que nada mais é do que a adoção de outro paradigma, isto é, muda-se a visão de mundo.

\section{Feyerabend}

A ciência possui complexas situações realistas além da impossibilidade de previsão do seu desenvolvimento, não sendo possível esperar que regras a expliquem. Com base nesse pressuposto, Feyerabend se apresenta contra metodologias fornecedoras de regras. Salienta ainda que, sendo a história tão complexa, é difícil esperar que a ciência possa ser explicada por meio de regras metodológicas simples, se pondo contra a validade universal de qualquer regra (CHALMERS, 1993, p. 174).

Contudo, Feyerabend comenta em um artigo que precedeu seu livro Against Method, que "vale-tudo" não deve ser levado ao pé da letra, ou seja, de forma ampla demais. Diferente do "pensador respeitável", o charlatão se faz por satisfeito em defender um ponto de vista em sua forma original e não está preparado para problemas em sua pesquisa, nem para corroborar de forma definitiva todas as situações que podem favorecer o oponente. Já o cientista razoável, este se atém aos detalhes, ás objeções, ao todo da investigação. Além disso, Chalmers acrescenta que "na ciência não se dá o fato de que vale-tudo sem limites" (CHALMERS, 1993, p. 176).

Ao se pensar na escolha de uma teoria entre muitas, os critérios de comparação para a escolha da teoria também devem ser pensados, se tratando, segundo Feyerabend, de uma análise subjetiva. Por meio das leituras sobre as visões de Feyerabend devemos entender que 
ele não se coloca contra nenhum método em particular. O que ele coloca é que não devemos achar que existe um método único que funciona em todos os casos, pois cada pesquisa requer um tipo de procedimento diferenciado e adequado ao propósito da pesquisa.

Nesse bloco buscamos o desenvolvimento das seguintes competências e habilidades dos alunos:

$\checkmark$ Ler e interpretar texto

$\checkmark$ Exercitar a escrita e a oralidade.

$\checkmark$ Organizar, relacionar, selecionar e interpretar dados e informações.

$\checkmark$ Relacionar informações representadas na forma escrita e conhecimentos prévios para construir uma argumentação consistente.

$\checkmark$ Fazer anotações e sínteses.

\subsubsection{Bloco 4: Atividades práticas}

\section{Aula 1 e 2}

-Objetivos específicos: O objetivo central dessa proposta é que os alunos trabalhem suas habilidades de argumentação e que a cena de mistério criada pelo professor seja debatida, mas não necessariamente que o caso seja solucionado, colocando os alunos na posição de quem está na busca do conhecimento. Além disso, aumentar a compreensão das teorias epistemológicas trabalhadas no Bloco 3.

-Conteúdos conceituais: Entender as ideias de Popper, Kuhn, Feyerabend e as visões empiristas sobre a construção da ciência.

-Conteúdos atitudinais: Capacidade de argumentação, atenção, respeito, participação.

-Conteúdos procedimentais: Compreender os procedimentos da realização de uma atividade prática.

-Conteúdos procedimentais: Análise de um cenário de crime

- Roteiro da aula: Esta atividade poderá ocorrer em um porão, sala de aula ou em outro ambiente que simule o local de um assassinato, conforme o relatado no livro $O$ caso da borboleta Atíria. Este cenário deverá ter itens referentes à história do livro, mas também poderá ser incrementado com outros elementos inerentes de cenas de crime convencionais. 
Esse cenário será elaborado pelo professor que levará os alunos a esse ambiente para que levantem hipóteses do que pode ter acontecido neste local e tentem desvendar o crime. Para essa investigação, os alunos trabalharão juntos, porém, com funções diferenciadas e bem definidas dentro da situação. Tais figuras podem ser a de chefe, de policial, de detetive, de perito (cientista), entre outros, onde cada um exponha seus pontos de vista sobre o crime baseados em sua profissão. Nessa proposta, os alunos irão trazer para a discussão elementos presentes nas teorias apresentadas na aula expositiva do Bloco 3.

- Tempo: 50 minutos para análise da cena e 50 para explicarem seus pontos de vista na resolução do enigma.

-Recursos didáticos: Além das pistas presentes no livro o professor poderá inovar colocando outras pistas, como por exemplo, marca de sangue, de pegada, copo com marca de batom, objeto de uso pessoal, fragrâncias, objetos, etc.

-Modalidade didática: Atividade prática.

-Pré-requisitos: Aulas do Bloco 2 - Leitura compartilhada e do Bloco 3: Teorias epistemológicas da construção da ciência.

-Forma de avaliação: Atuação na análise do cenário, clareza nas explicações baseadas no aprendizado das teorias epistemológicas e participação.

\section{Aula 3}

-Objetivos específicos: Levar os alunos ao entendimento de que a ciência não tem uma única forma de construção e aguçar o poder de argumentação dos alunos.

-Conteúdos conceituais: Teorias epistemológicas da construção da ciência.

-Conteúdos procedimentais: Atividade em grupo Levantamento de ideias.

-Conteúdos atitudinais: Trabalho em grupo, argumentação, parcerias e respeito.

-Roteiro da aula: Com base no cenário trabalhado na aula anterior, na qual os alunos analisaram os fatos e levantaram hipóteses para a confirmação de suas ideias, propomos a realização de um momento de defesa dos quatro pontos de vistas trabalhados no Bloco 3. A sala poderá ser dividida em quatro grandes grupos que irão expor seus argumentos por meio do debate. Queremos que os alunos reflitam sobre qual teoria é a mais adequada para a cena. Com isso, esperamos que os alunos entendam que a ciência não tem uma única forma de construção, e por isso, há diferentes visões. Caberá ao professor a mediação desse debate e a elucidação de dúvidas que possam vir a permear a discussão. 
-Recursos didáticos: Cenário, giz e lousa. O professor poderá, caso desejar, utilizar um computador com projetor e um programa de digitação para o registro das colocações.

-Tempo: 25 minutos para explicar a proposta e organizar os grupos, 35 minutos para os grupos fazerem suas análises e 40 para a apresentação dos resultados.

-Modalidade didática: Aula expositiva e prática com discussão em grupo por meio de exposição dialogada.

-Pré-requisitos: Aulas do Bloco 2 - Leitura compartilhada e do Bloco 3 - Teorias epistemológicas da construção da ciência.

-Formas de avaliação: Comportamento e atuação dos alunos durante o debate, assim como as colocações e o engajamento na atividade.

Nesse bloco buscamos o desenvolvimento das seguintes competências e habilidades dos alunos:

$\checkmark$ Organizar, relacionar, coletar, selecionar e interpretar dados e informações.

$\checkmark$ Relacionar informações representadas na forma escrita e conhecimentos prévios para construir uma argumentação consistente.

$\checkmark$ Fazer anotações e sínteses.

$\checkmark$ Interpretar situações do cotidiano.

$\checkmark$ Ouvir a exposição dos colegas, registrando e esperando sua vez de falar e sabendo argumentar quando não concordar com uma posição.

$\checkmark$ Ler, interpretar e fazer o uso de diferentes linguagens.

$\checkmark$ Conduzir uma aula prática com base em um roteiro.

$\checkmark$ Fazer pesquisa, buscar informações em livros, textos, etc.

Todas as propostas apresentadas nesses quatro blocos são exemplos de atividades pautadas no romance policial que objetivam ajudar o aluno a adquirir habilidades relacionadas com o aprender a aprender, se tornando cada vez mais autônomos em suas aprendizagens.

\subsection{AMOSTRA DAS APLICAÇÕES}

As propostas criadas neste trabalho foram aplicadas em uma escola da Rede Estadual de Ensino, pertencente à Diretoria de Ensino Norte 1, situada na zona Oeste da Cidade de São Paulo. Essa escola abrange os três níveis de ensino, o Ensino Fundamental I e II e o Ensino Médio. As atividades foram aplicadas em uma sala de cada ano do Ensino fundamental II, ou seja, no $6^{\circ}, 7^{\circ}, 8^{\circ}$ e $9^{\circ}$ ano, com a realização das adequações necessárias. 
Os resultados das aplicações das atividades serão apresentados de forma rápida e sucinta apenas para ilustrar os resultados obtidos que foram utilizados para o aprimoramento das propostas didáticas. Tais resultados servirão de material para um trabalho de continuação dessa pesquisa, nos restingindo a mostrar nesse tópico apenas alguns exemplos.

No $9^{\circ}$ ano $\left(8^{\circ}\right.$ série $)$ aplicamos três dos quatro blocos didáticos. Durante a aplicação do Bloco 2, fizemos uma leitura de forma compartilhada dos capítulos propostos, utilizando apenas um livro, com o objetivo de entender como essa atividade se daria caso a escola não dispusesse de recursos materiais ou de condições de cópias dos capítulos utilizados. Alguns alunos de dispuseram a fazer a leitura enquanto outros quiseram apenas ouvir. Os alunos leitores se sentiram a vontade para ler grandes trechos do livro e foram muito incentivados pelos outros e elogiados pela clareza na leitura.

Percebemos que de um total de 25 alunos, cerca de $90 \%$ gostaram da atividade extraclasse e da história do livro e pediram que atividades como essa se tornassem mais comuns no dia-a-dia escolar. No decorrer da leitura, grande parte se atentou a leitura, porém, alguns alunos se dispersaram. Fizemos a leitura em um pátio que fica ao lado do jardim da escola com o propósito de associar o local, por meio de sons, cheiros e espaço físico com o cenário da escola. A mudança de ambiente, com a saída dos alunos da rotineira sala de aula foi muito bem recebida. Para essa sala resolvemos levar cadeiras para que os alunos se sentissem mais a vontade, pois em outra atividade em que os alunos se sentaram no chão, fazendo uma roda de leitura, alguns reclamaram da posição, que com o passar do tempo foi se tornando incômoda. Esse cenário pode ser visualizado nas imagens a seguir:

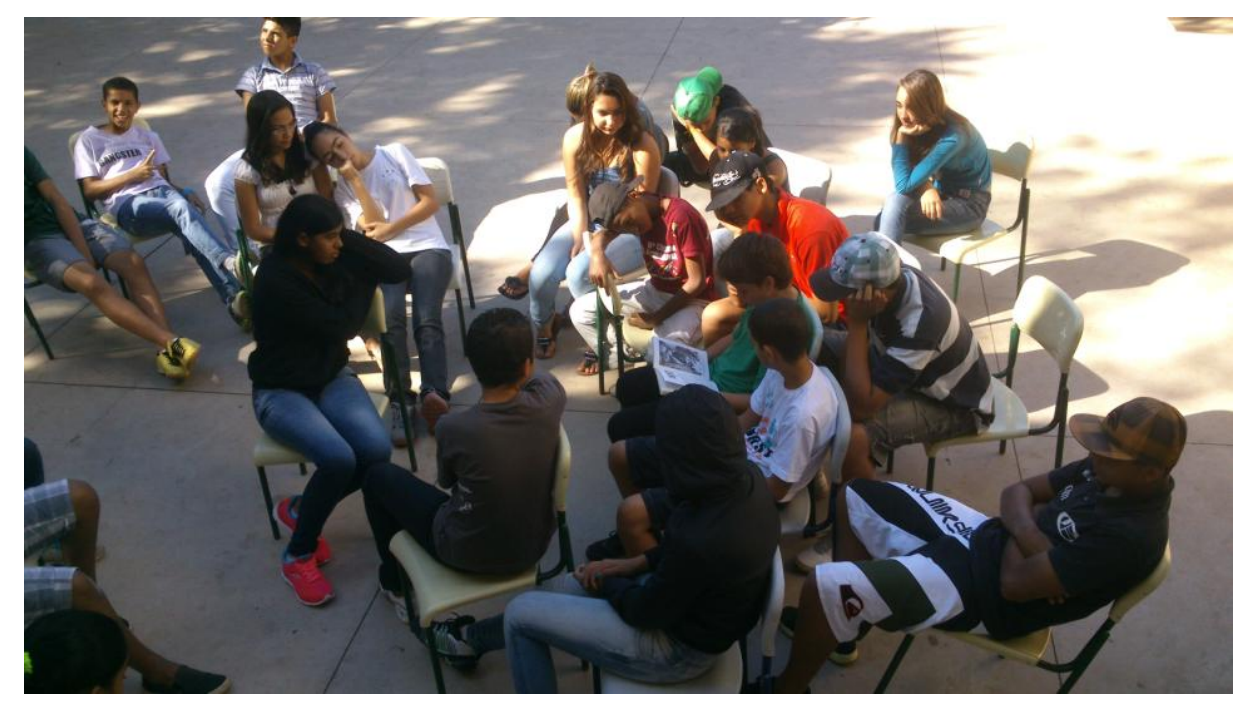

Figura 22 Leitura compartilhada 
Após a leitura, que teve uma duração de três aulas, divididas em dois dias, fizemos na aula seguinte uma conversa sobre a história para que os alunos relembrassem os pontos principais. Após essa conversa, como atividade principal, propomos aos alunos que registrassem a partir do que entenderam da história e com base apenas em seus conhecimentos prévios, o que eles entendiam por fatos, pistas e hipóteses e em que situações eles visualizaram tais pontos na história. Pedimos também que eles opinassem sobre qual (is) seria o personagem (ns) que eles julgassem ser (em) o (s) assassino (s).

Vejamos algumas respostas nas atividades apresentadas a seguir:

Attiria, a personagem prinscipal do livero ers uma borboleta que tersha um defeita em uns de suas asas. dla morona num bosque innenso, e lá tinha o principe Gribe sua noiva Meliconia que foi brutalmente assassina da num local io bosque chomado o. Antro das knuxas Noturans, outra personagem bi assassinada Vanessa Atalanta, una bossoleta estrangaira, que tinha viajado para - bosque, apas a assassinato de vanersa com uma erva chamada Mancenitha, surgiram abumas aistar, coms a conversa de dois insetos falondo sobre a feits deles à Helicómia è à Vamessa, ascutadr pelo principe gribue nessa comoersa um dos insctas conversava com uma conyza, a principe trilo suspeitara de uma cosyja agós o mencienamento dessa palavra anterionmente muma hutaria de que o principe nas re lembrova, e na consaersa, dizia sobre o cossinel assassinato ds Attiria, de cuma rersa se sabia, have a um assassino 6

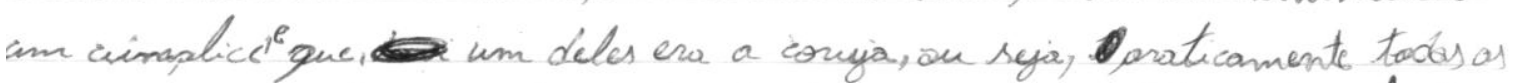

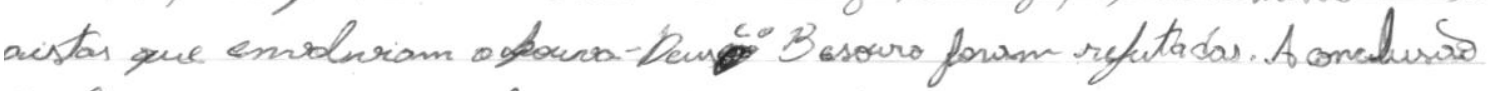
- é que assassino be a Conyza.

Figura 23 - Relato de um aluno sobre hipóteses e fatos da história

Nessa atividade o aluno relata que por meio de uma conversa ouvida pelo detetive Papílio, podemos afirmar que há um assassino e um cúmplice e que o Louva-Deus e o bezouro não poderiam ser enquadrados como assassinos por causa dos fatos que surgiram. Nessa atividade vemos que o aluno visualiza que algumas pistas geraram hipóteses, sendo que algumas delas foram refutadas e outras corroboradas. $\mathrm{O}$ mesmo acontece na escrita a seguir: 
Is fotos í que duas berlacletas tinhom Jído matos mos ninguén motoroma jalia quem eva as assaimos encentronom eta morta no Antro das Brwas mas ninguem realmente sobe or que ocontecer,e quiem a matioutintaw o Detetive popílis Comegou a procuror biobre pistas. pora descobir quem que ter essa fotadoda a ficor sté descevin quem motar Helicañia f pistas evam a do fantasmas, uittinnos polarlas que vonesse folou "Conyz" i as insetos folando um com atro. A pista refutado ¿́ a do fontosma, por que ele se envoraleau todo de teia de crancha e ficeas covendo de un lado pera untro. Buem era is assosimos na minha opiniño é a prinćpe, por que nos devas mortes ile tara sempre ho maio, a a Corija por que - o Detetive popilis eluvir une comversa que um dizie is nome Corrija.

Figura 24 - Relatos da história

Na próxima atividade vemos que a aluna mostra que a ausência de pistas dificulta a investigação e que a conversa que o detetive ouviu no bosque foi fundamental para resolver o mistério.

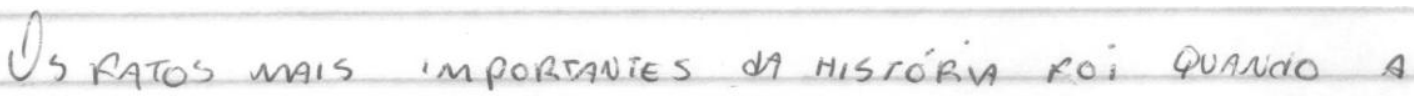
PRINCESAHELICONIA MORREU UAO haU

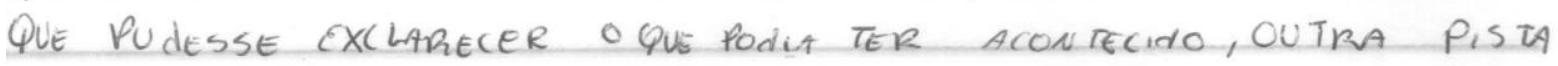
FOI A QUE TINIVA dOIS WSETOS CONVERSANdO E O dETETLVE

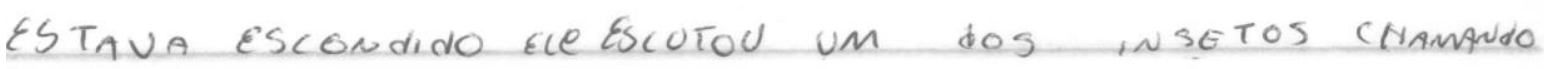
- OUTRO de coruSA, O QUE deO UMA EVORME PISTA, DE YVEM ISdERIA ter matado a pRUCESA uANESSA. QUE MORRPU AOLAdO dE UMA ERUA VEUENOSA.

Figura 25 - Atividade sobre a história

92 
Nas escritas dos três alunos, eles indicaram a coruja como sendo a assassina. Até esse momento da leitura, com as informações passadas no livro, tudo leva a crer que a coruja seja realmente a assassina, ou seja, eles acompanharam bem a leitura. Em contrapartida, alguns alunos não sabiam indicar quem poderia ser o assassino. Alguns alunos argumentaram que não tinham informaões suficientes e outros não souberam explicar. Entendemos que isso possa ser resultado da falta de atenção á leitura ou por não conseguirem estabelecer relações com as informações fornecidas.

Em continuidade a atividade, os alunos tiveram que escolher um personagem que pudesse ser comparado analogamente a um cientista e explicar o porquê de sua escolha. Também pedimos que relacionassem a história com a pesquisa científica e relatassem quais conteúdos de ciências apareceram na história, afinal o enredo da história remete a curiosidades e informações científicas sobre os personagens da trama e essa atividade ocorreu em uma aula de ciências. Vejamos algumas respostas:

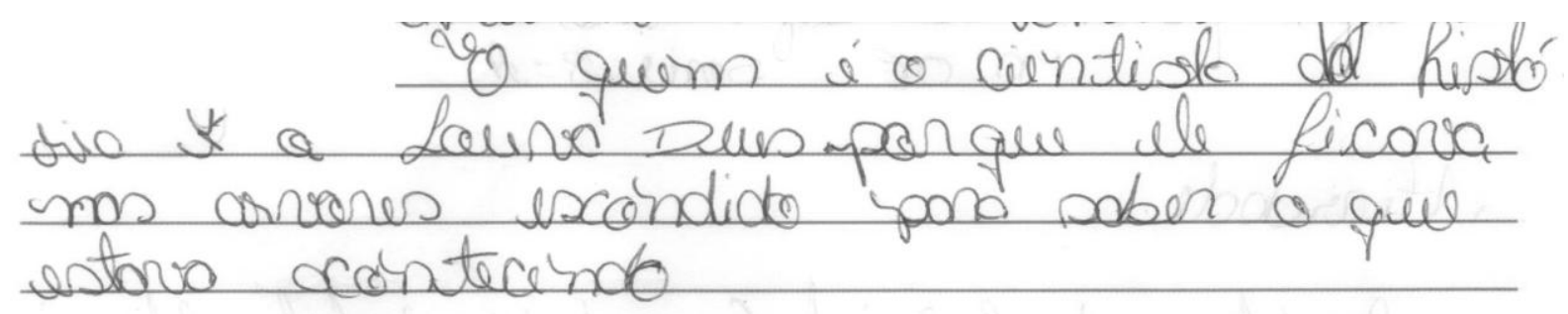

Figura 26 Relacionando o detetive com o cientista

$\mathrm{Na}$ atividade da figura anterior, o detetive Papílio não foi escolhido como sendo a figura que mais se aproximava do cientista, foi feita a associação com o Louva a Deus, e a aluna justifica sua resposta dizendo que ele vivia escondido atrás das árvores para descobrir o que estava acontecendo, fazendo uma analogia do cientista com alguém que investiga.

No relato da figura a seguir, vemos que o aluno entende que o trabalho científico possui algum rigor de precisão e que as informações devem possuir veracidade para serem aceitas. 
Arelaces Sessa história com unne pesquisa cientifica de seguinte, o dete-

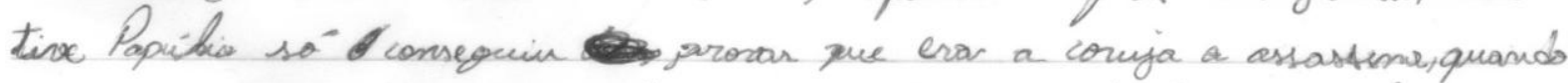

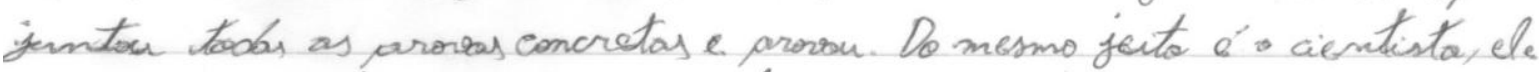
só pode plizer algo que de tem certega vépois de muitos testes e provars ca ientista desta historir docio Davilio.

Figura 27 Relacionando a história com a pesquisa científica

Nos dois exemplos a seguir vemos o que os alunos identificaram como sendo conteúdos de ciências que estavam presentes no livro.

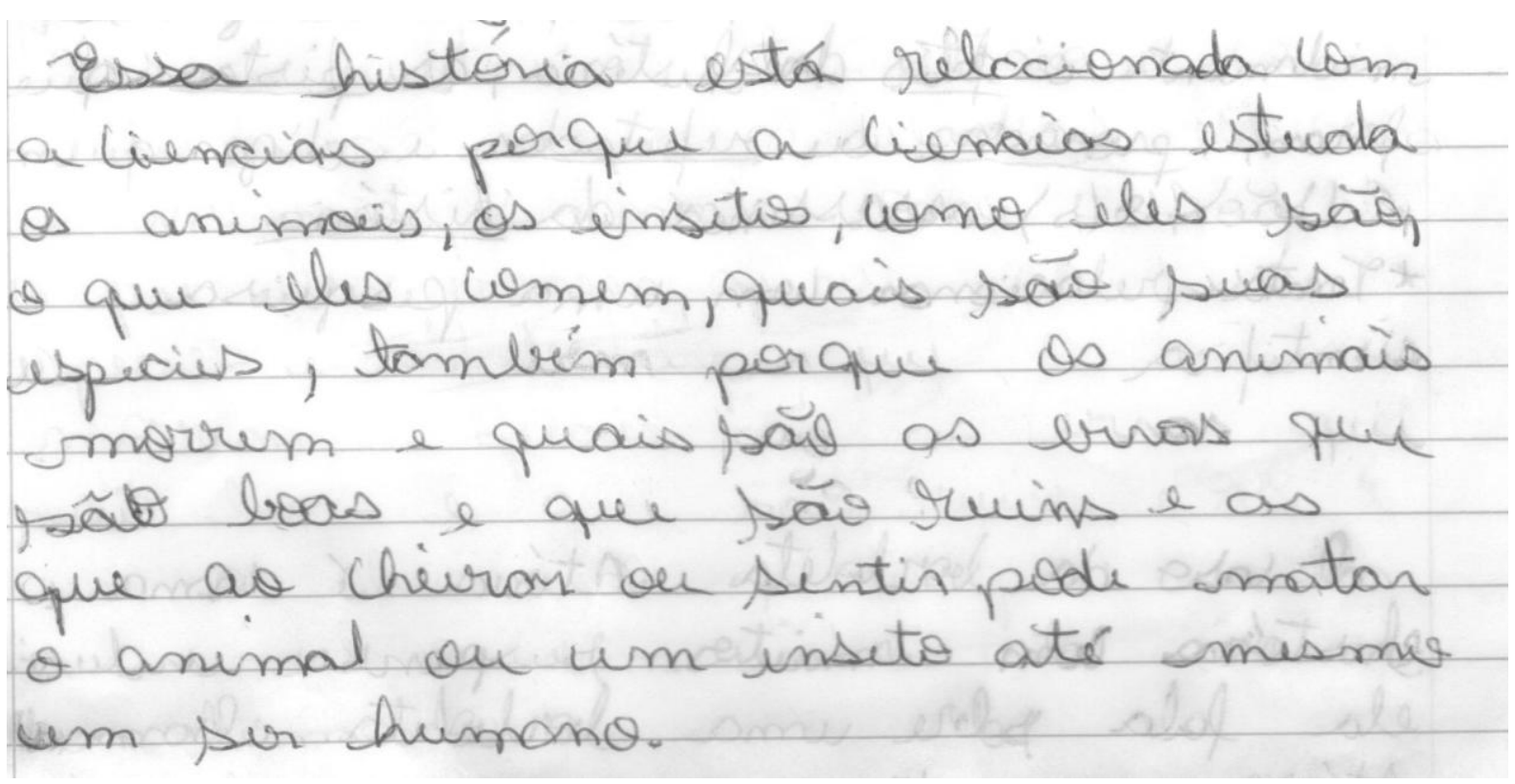

Figura 28 Conteúdos de ciências

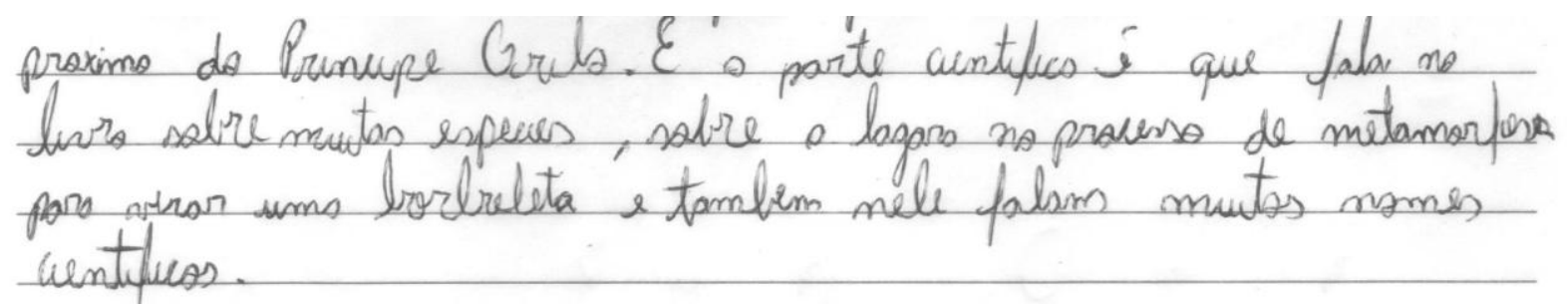

Figura 28 Conteúdos científicos

Por meio dessas atividades, percebemos que em sua maioria, os alunos conseguiram identificar e classificar o que eram fatos e o que eram hipóteses e sua importância para que o mistério fosse desvendado.

Percebemos que cerca de 15\% dos alunos não conseguiram relacionar a história com a 
pesquisa científica, dando mais ênfase em suas escritas para os outros pontos que foram pedidos. Cerca de $95 \%$ dos alunos associaram o detetive Papílio com o cientista e entre os que não associaram poucos souberam explicar o porquê de suas escolhas. Os que conseguiram explicar elegeram personagens que também estavam investigando e averiguando os fatos para a descoberta do mistério. Todos os alunos souberam apresentar exemplos de conteúdos de ciências relatados no livro e relataram no decorrer da leitura, acharem interessantes algumas informações novas que aprenderam. 


\section{CONSIDERAÇÕES FINAIS}

No decorrer da pesquisa percebemos as mudanças que a literatura infanto-juvenil foi sofrendo com o passar do tempo, assim como sua recepção por parte de alguns críticos, que a priori, viam-na como uma literatura menor, que não possuia uma escrita bem elaborada, e que por ser simples e voltada para um público de uma faixa etária mais baixa, não poderia ser enquadrada no mesmo patamar de importância de uma literatura de peso. Com o decorrer do tempo, a literatura infanto-juvenil foi ganhando espaço, ao apresentar em sua escrita qualidade literária e por abordar em seu enredo temas diversos, passando a se tornar para muitos uma literatura de prestígio.

Vimos que sua escrita e publicação no Brasil foram tardias, e que a princípio eram norteadas por caracterísitcas europeias, pois os padrões de intelectualidade e estética literária aceitos na Europa e consequentemente em Portugal foram repassados para o Brasil na época da colonização. Com o passar do tempo, as características brasileiras passaram a ser inseridas nas obras literárias, fazendo com que o enredo fosse mais regionalizado, fazendo parte do contexto sócio cultural do leitor. Autores brasileiros de literatura infanto-juvenil ganharam mais espaço e passaram a escrever cada vez mais obras, aumentando assim, o número de exemplares, a qualidade das escritas e a quantidade de autores de renome.

Com isso, livros de diversos gêneros literários puderam se popularizar e estarem acessíveis a um número maior de leitores. $\mathrm{O}$ fato da literatura sempre estar presente no contexto escolar pode significar que a escola tenha sido o local onde as crianças e os jovens tiveram o primeiro contato com a literatura. Diversos livros são apresentados aos alunos e por meio deles, tais leitores podem se deleitar e viajar no mundo da fantasia e do cotidiano dos personagens que fazem parte da história, podendo muitas vezes se identificar com a história e se perceberem como atores dessa história. $\mathrm{O}$ contexto literário, que muitas vezes é composto por ficção, magia e imaginação, ao mesmo tempo, apresenta situações muito parecidas com as vividas pelos leitores, proporcionando-lhe experimentar sensações que não são comuns em sua vida e ao mesmo tempo amplia sua visão de mundo, com uma leitura que lhe possibilita um olhar diferenciado e crítico de sua realidade.

Além dessas, a literatura possui múltiplas possibilidades que podem ser exploradas no contexto escolar, como a ampliação da qualidade da leitura, melhorando o letramento de seus leitores, conhecer outros mundos, estimular a imaginação, a criação e a criticidade, além de 
possibilitar o trabalho de conteúdos que fazem parte do currículo escolar de maneira diferenciada e estimulante. Notamos também que a obra de literatura possibilita a criação de atividades diferenciadas, o ensino de conteúdos que fazem parte do currículo e temas transversais, ampliando-se o projeto pedagógico da escola. Tais características foram fundamentais para a escolha da literatura como recurso nesse trabalho, em especial, o romance policial, por apresentar possibilidades de trabalhar a temática escolhida. Conforme mostramos, trabalhar a investigação científica irá possibilitar ao leitor o entendimento da forma como a ciência é construída, ou seja, como se dá o desenvolvimento da ciência tendo como consequência avanços que são percebidos no cotidiano do leitor, sendo um recurso a mais para a abordagem desse conteúdo. Além do mais, esse tema não é abordado enfaticamente no ensino de ciências devido à ideia de que é algo complexo e que não será entendido por estar distante da realidade dos alunos. Essa é uma das falas de alguns professores de ciências com quem tivemos contato durante a experiência da prática escolar, além do pequeno espaço dispensado ao tratamento desse assunto nos recursos didáticos disponíveis na rede escolar.

Entendemos que assim como os resultados da ciência fazem parte do cotidiano dos alunos e modificam suas vidas, eles também devem ter acesso ao entendimento de como essa ciência é construída. Para tal, o romance policial foi escolhido por apresentar características que possibilitam esse trabalho. Tais características foram identificadas por meio de análises realizadas na obra $O$ caso da borboleta Atíria que foi explorada como um modelo de romance policial a ser utilizado, se apresentando como melhor recurso nesse sentido.

Por meio das análises percebemos que o romance policial é permeado pela investigação, pois, no decorrer da história, para que o mistério seja desvendado, ocorre a investigação com o objetivo de encontrar o assassino. Percebemos que tal percurso tem como foco a busca do saber, considerando-se que o detetive da história esteja em constante investigação, buscando pistas, levantando hipóteses, testando os dados e enquadrando-os em informações que podem ser refutadas ou corroboradas e assim, usadas na elaboração de uma conclusão. Com a resolução do mistério chegamos à sanção da história, que é o objetivo principal a ser alcançado em uma trama de mistério. Essas sequências de ações vão de encontro com os conteúdos procedimentais de realização de uma pesquisa científica, que também tem como foco a busca do saber. Essas associações foram possibilitadas pela análise semiótica, tendo Greimas como aporte teórico. Essas constatações corroboram a ideia de que a obra pode ser utilizada no ensino da investigação científica, pois o fato dos romances 
policiais trabalharem e estimularem o poder de investigação do leitor, tendo como foco desvendar o mistério, ou seja, a busca do conhecimento. Podemos utilizar o gênero por meio de analogias no trabalho da investigação científica, que também objetiva explicar os fenômenos naturais, buscando o saber. Isso pode ser ampliado para outros romances policiais, pois todos utilizam os recursos mentais para desvendar os mistérios.

A obra literária escolhida foi importantíssima nesse trabalho, pois além de possibilitar esse trabalho, ela apresenta uma gama de conteúdos que podem ser trabalhados no contexto pedagógico. Esses conteúdos presentes na obra foram esmiuçados e mostram o caráter pedagógico que ela tem, afinal, por meio da análise do discurso tendo Maingueneau como aporte teórico principal, vimos que a obra não foi concebida para o ensino de ciências, mas foi adotada pela editora Ática por possuir tais características e por ter o público infanto-juvenil escolar e não escolar como público alvo, caracterizada por ter uma linguagem acessível e por apresentar em seu enredo conteúdos científico.

Com isso, percebemos que mesmo que alguns romances policiais são sejam concebidos paradidaticamente para o ensino, eles podem ser utilizados neste sentido. Claro que, o uso da obra no ensino de ciências poderá ser feito se o autor da obra escolhida, assim como a autora Lúcia Machado de Almeida de $O$ caso da borboleta Atíria, se interessar por conteúdos científicos e isso se refletir em sua escrita. Na história de Atíria, a autora apresenta informações de cunho científico, possibilitando ao leitor o contato com termos inerentes de leituras do gênero científico, mostrando que ela se preocupa com a pesquisa, se tornando uma incentivadora não só da leitura, mas também da transmissão de conceitos científicos.

Tudo que foi apresentado até o momento foi realizado com a intenção de levantar a possibilidade da aplicação didática do livro em sala de aula utilizando-o como um recurso diferenciado no ensino ciências. A abordagem por meio do livro sai da rotina dos métodos de ensino tradicionais e pode gerar por meio da leitura e pesquisa um aprendizado diferenciado e eficaz. É uma possibilidade educativa de fácil acesso que pode ser aplicado tanto como entretenimento e lazer, bem como, no ensino de ciências no ensino fundamental.

A partir das análises e estudos feitos na obra, visualizamos as possibilidades didáticas do livro e propomos atividades para o trabalho em sala de aula. Essas atividades foram elaboradas visando o debate da construção da ciência e propostas como forma de auxílio ao professor no tratamento desse conteúdo. As atividades foram pensadas para serem aplicadas em qualquer contexto escolar, pois não exige recursos de difícil acesso. Elas são bem flexíveis no sentido de possibilitar ao professor a escolha dos blocos ou aulas que queira aplicar 
pensando no seu público e no contexto em que a escola está inserida, assim como, no tempo disponível, tendo em vista a alta de gama de atividades pedagógicas diárias do professor.

A partir das propostas o professor poderá por meio de aulas práticas e teóricas, utilizar em sala de aula diversas estratégias de ensino como, debate, questionamentos, simulações em situações de aprendizagens voltadas para o ensino da investigação científica. Os debates estimulam uma visão crítica do conteúdo, ao colocar o aluno como seres pensantes e atuantes na produção do conhecimento. Além dos conteúdos apresentados nas propostas, incentivamos que seja feito um trabalho de cunho interdisciplinar com professores de outras disciplinas que não seja ciências, pois o livro traz essa possibilidade. Temas como, amizade, relações sociais, relação familiar e adoção são temas possíveis de serem trabalhados caso o professor deseje.

Devemos levar em consideração também os obstáculos que serão encontrados no uso dessa proposta. Sabemos que em uma sala há alunos com níveis de aprendizado diferentes, onde haverá alunos que possuem uma escrita e a oralidade muito boa e em contrapartida, outros que não conseguem ler eficazmente. Da mesma forma, assim como encontramos na aplicação de algumas das propostas, haverá alunos que leem, mas não entendem o que estão lendo, afinal, a leitura exige um grau de concentração e deve ser feita em um ambiente que seja favorável, por isso é importante a figura do mediador, que deverá criar uma situação que possibilite ao leitor uma maior apreensão da leitura.

Outro ponto que poderá gerar dificuldades na realização dessa proposta é o atual cenário em que vivemos, onde os alunos estão com seus olhares voltados para as tecnologias da informação estão em alta em praticamente todos os campos do conhecimento humano. Sabemos que poucos são os que não dedicam sua total atenção aos celulares, computadores e tablets e que estão ligados o dia inteiro em músicas, filmes, redes sociais, salas de bate-papo. Hoje nossos alunos estão acustumados com leituras rápidas de posts e propagandas, por isso, acreditamos que esse cenário possa ser um dos motivos que faz com que os alunos vejam o livro como algo extenso e cansativo, deixando de fazer uma pausa para uma boa leitura.

Em contrapartida, também há livros que são extensos e que fazem grande sucesso entre os jovens, principalmente os que são marcados por pitadas de mistério e magia, mostrando que caso sejam bem escolhidos podem cativar seus leitores. Há diversos livros que foram escritos a algum tempo e que são cativantes, mas que muitas vezes não são apresentados aos leitores atuais. Acreditamos que $O$ caso da borboleta Atíria seja um desses exemplos e que deve ser apresentado ao público infanto-juvenil. Seu sucesso em sala de aula dependerá da abordagem dada ao livro pelo professor, por isso, inclusive, apresentamos 
diversas propostas de como deve ser feita essa leitura e cada professor deverá escolher a mais apropriada pensando nas especificidades de seus alunos.

Em uma pesquisa anterior tive a oportunidade de trabalhar com filme de animação do gênero ficcional. A partir dessa experiência, tive o prazer de perceber a grande aceitação que tal recurso teve em sala de aula e faço seu uso até hoje, não só no trabalho de temáticas ambientais como com temas de astronomia, genética e relações interpessoais. Da mesma forma, percebi que a eficácia do recurso não é homogênea, afinal temos alunos com características bem heterogêneas umas das outras, e isso foi importante para que eu pudesse saber que adaptações deveriam ser feitas.

O mesmo acontece com a literatura, que oferece várias possibilidades assim como o filme, em especial, o romance policial, que nos possibilita viajar no mundo da ficção e da imaginação, nos coloca na cena do crime como investigadores, estimular nossos hábitos de leitura e nos fornece diversas informações que muito tem a nos acrescentar e que a tempos está presente nas bibliotecas escolares, fazendo parte do acervo da escola. pois nas aplicações que eu realizei, pude obter retornos distintos e como o foco do trabalho não é este, deveremos posteriormente fazer uma aplicação mais sitematizada em sala de aula com o intuito de aprimorá-las e fazer as mudanças que entendermos serem necessárias para sua melhoria, pensando nessas especificidades que são inerentes de cada sala, série ou escola.

Algumas dificuldades foram vivenciadas com o uso da literatura, pois durante a aplicação percebemos que os alunos possuem níveis de leitura e escrita diferenciados, por isso poucos foram os alunos que se ofereceram para ler o livro $O$ caso da borboleta Atíria. $\mathrm{O}$ mesmo se deu nas escritas dos alunos, que apresentavam grandes erros de ortografia e concordância. Nas respostas das questões das atividades escritas, percebemos que alguns tiveram dificuldades em responder as questões de forma crítica e embasada, ou por não terem prestado a total atenção à história ou por não dominarem o poder de argumentação.

Percebo que poucos professores utilizam a literatura no ensino de seus conteúdos, ficando a cargo apenas da disciplina Língua Portuguesa, porém, percebemos nesse e em outros trabalhos que está crescendo cada vez mais o uso da literatura como recurso no ensino, que terá como foco não mais apenas a leitura e a oralidade mas também trabalhar outros conteúdos presentes no livro. Como dissemos anteriormente, os escritores são interessados por assuntos diversos e isso se reflete em suas escritas e o professor pode se apropriar mais desse recurso para explorar esses conteúdos. Essa prática muitas vezes não é realizada porque não há muitas propostas nesse sentido ou porque eles não veem relevância por não 
conhecerem. Sendo assim, devemos apresentá-las para que possam ser conhecidas e utilizadas.

Pensando em tudo isso, por meio desse trabalho pudemos entender mais a fundo as qualidades da literatura infanto juvenil, suas possibilidades e dificuldades pedagógicas, tendo agora mais bagagem para continuar esse trabalho por meio de uma pesquisa prática sistematizada de aplicação da literatura e das propostas aqui apresentadas. Tendo esse trabalho como ponto de partida, pretendemos agora nos dedicar a levar as propostas para a sala de aula, para que sejam efetivamente utilizadas e obter resultados avaliativos e concisos. Esse é o início de um grande caminho a percorrer tendo a literatura infanto juvenil como meio de transporte que irá nos conduzir. 


\section{REFERÊNCIAS}

AGUIAR, R.X. O critério de empiricidade em Karl Popper, Síntese Nova Fase, Belo Horizonte, v 25 n. 81, p. 285-292, 1998. Disponível em: <http://www.faje.edu.br/periodicos/index.php/Sintese/article/viewFile/774/1206>. Acessado em: 15 de jan, 2013.

ALBUQUERQUE, P. M. O mundo emocionante do romance policial. Rio de Janeiro: F. Alves, 1979.

ALMEIDA, M. J. P. M. O texto escrito na educação em física: enfoque na divulgação científica. In: ALMEIDA, M. J. P. M; SILVA, H. C. (Org.). Linguagens, leituras e ensino da ciência. , p. 121-130.Campinas, SP: Mercado de Letras; ALB, 1998.

ALMEIDA, L. M. de. O Caso da borboleta Atíria. São Paulo: Ática, 1991.

BAKHTIN, M. e VOLOSHINOV V. Marxismo e filosofia da linguagem. 11 edição. São Paulo: Hucitec, 2004.

BARROS, D. L. P. Teoria do discurso: fundamentos semióticos. São Paulo: Humanitas, 2001.

BARTHES, R. et. al. Literatura e Semiologia - Seleção de Ensaios da revista "comunications". Coleção Novas Perspectivas em Comunicação 3. Rio de Janeiro: Vozes, 1972.

BAZARIAN, J. O problema da verdade. 4. ed. São Paulo:. Alfa-Omega, 1994.

BOILEAU, P.; NARCEJAC, T. O romance policial. São Paulo: Ática, 1991.

BORELLI, S. H. S. Ação, suspense, emoção. Literatura e cultura de massa no Brasil. São Paulo: Estação Liberdade, 1996.

BRASIL. Lei de diretrizes e bases da educação. 1996. 31p. Disponível em: <http://www.planalto.gov.br/ccivil_03/Leis/L9394.htm>. Acessado em: 20 de mar. 2013

CADEMARTORI, L. O professor e a literatura: para pequenos, médios e grandes. Belo Horizonte : Autêntica, 2012, $2^{\circ}$ ed.

CAMPOS, M. C. C; NIGRO, R. G. Didática de Ciências: o ensino aprendizagem como investigação. São Paulo: FTD, 1999.

CARVALHO, B. V. C. Literatura Infantil: Estudos. Edição s. d. - 382 pp. São Paulo: Lotus, 1989.

COELHO, N. N. Dicionário Crítico da literatura infantil e juvenil brasileira. São Paulo: 
Quiron, 1983.

Teoria - análise - didática. São Paulo: Ática, 1993

COLOMER, T. A formação do leitor literário.São Paulo: Global, 2011.

COTRIM, G. Fundamentos da filosofia. São Paulo: Saraiva, 1997

DANTON, G. Ciência e quadrinhos. $1^{\circ}$ Edição. João Pessoa: Marca de Fantasia, 2005.

EDITORA ÁTICA. Dados sobre a obra O caso da borboleta Atíria. [Informamos que a Obra citada (Caso da Borboleta Atiria, da Autora Lucia machado de Almeida) é editada e vendida pela editora Ática, as demais informações não podemos fornecer por serem confidenciais da empresa.]. Mensagem recebida por < atendimento@atica.com.br> em 2 de junho de 2011.

FERNANDES, C. R. D. Leitura, literatura infanto-juvenil e educação.Londrina: EDUEL, 2007.

FIGUEIREDO, V. L. F. de. O assassino é o leitor. In: Revista Matraga. V. 2, n. 4-5. Rio de Janeiro: jan./ago, 1988.

FILHO, J. N. G. Literatura juvenil: adolescência, cultura e formação de leitores. São Paulo: Melhoramentos, 2011.

FIORIN, J. L. As astúcias da enunciação. 2. ed. São Paulo: Ática, 1999. . Elementos de análise do discurso. 15 ed. São Paulo: Contexto, 2011. . Em busca do sentido: estudos discursivos. São Paulo: Contexto, 2008.

FREIRE, P. A importância do ato de ler: em três artigos que se complementam. 41. Ed. São Paulo, Cortez, 2001b. . Semiótica do discurso científico. Da modalidade. São Paulo: Difel: Sociedade

GONNET, J. Educação e mídias. Tradução brasileira: Maria Luiza Belloni; estado: Editora Loyola, 2004.

GREIMAS, A. J. Semântica estrutural. $2^{\mathrm{a}}$ edição. São Paulo: Cultrix: Edusp, 1976a. . Semiótica do discurso científico. Da modalidade. São Paulo: Difel: Sociedade Brasileira de Professores de Linguistica, 1976b.

GRILLO, S. V. C. Divulgação científica na esfera midiática. Revista Intercâmbio, vol XV. São Paulo, LAEL/-PUC-SP, ISSN 1806-275X, 2006.

HESSEN, J. Teoria do conhecimento. 2.ed. São Paulo: Martins Fontes, 2003.

JAKOBSON, R. Linguística e comunicação. São Paulo: Cultrix, 1974.

JESUALDO. A literatura infantil. Trad: AMADO, James. São Paulo: Cultrix, 1993. 
LAJOLO, M. Como e por que ler o romance brasileiro. Rio de Janeiro: Objetiva, 2004.

LALANDE, A. Dicionário técnico e crítico da filosofia . São Paulo: Martins Fontes, 1996.

LINSINGEN, L Von. Alguns motivos para trazer a literatura infantil para a aula de Ciências. Revista Ciência \& Ensino, vol. 2, n. 2, junho de 2008.

LOCKE, J. Ensaio sobre o Entendimento Humano. Fundação Calouste Gulbenkian, 1999.

MACHADO, C. E. Coleção Vaga-Lume comemora 40 anos com edição digital e versões no cinema. Folha de S. Paulo, São Paulo, 30 dez. 2012. Disponível em: <http://folha.com/no1207475>. Acessado: 10 de maio de 2013.

MACHADO, C. A. Filmes de ficção científica como mediadores de conceitos relativos ao meio ambiente. Ciência e Educação, v. 14, n. 2, p. 283-294, Curitiba, 2008.

MAINGUENEAU, D. Discurso literário. São Paulo: Contexto, 2006.

MENDONÇA, C. T. À sobra da Vaga-Lume: análise e recepção da série Vaga-Lume. Dissertação de Doutorado, UFPR - Curitiba, 2007.

MOYA, A . Shazam. São Paulo: Perspectiva, 1977.

NASCIMENTO JR, F. A. Quadrinhos de ficção científica e ensino de física: uma análise sobre o papel da ciência nas histórias do 'Quarteto Fantástico’ 2013. Tese (Dissertação em Ensino de Ciências (Modalidades Física)) - Universidade de São Paulo,São Paulo. 2013.

PCN: O que são? Para que servem? Nova Escola. Edição Especial. Parâmetros Curriculares Nacionais fáceis de entender. São Paulo: Abril, 1999.

PIASSI, L. P. C. Contatos: A ficção científica no ensino de ciências em um contexto sócio cultural. Tese de Doutorado. São Paulo: FEUSP, 2007.

. et al. O discurso ideológico sobre Aristóteles nos livros didáticos de Física. In: Revista Brasileira de Pesquisa em Educação em Ciências, Belo Horizonte, v. 9, n. 2, p. 1-19, maio/ago. 2009.

PIASSI, L.P.C.; PIETROCOLA, M. De olho no futuro: ficção científica para debater questões sócio-políticas de ciência e tecnologia em sala de aula. Ciência \& Ensino v. 1, p. 8, 2007.

Quem conta um conto aumenta um ponto também em física: Contos de ficção científica na sala de aula. Atas do XVII Simpósio Nacional de Ensino de Física, 2007, disponível em <http://www.cienciamao.if.usp.br/dados/ale/_ 2007quem.arquivo.pdf> (acessado em 09 de setembro de 2009).

Ficção científica e ensino de ciências: para além do método de encontrar erros em 
filmes. Educação e Pesquisa (USP), v. 35, p. 525-540, 2009.

PIETROFORTE, A. V. Semiótica Visual: os percursos do olhar. São Paulo: Contexto, 2007.

POPPER, K. R. A lógica da pesquisa científica. $16^{\circ}$ ed. São Paulo: Cultrix, 2008.

PORCHAT, O. P. Rumo ao ceticismo. São Paulo: UNESP, 2007.

PORTUGAL, C. A. Discussão sobre empirismo e racionalismo no problema da origem do conhecimento. Diálogos \& Ciência - Revista Eletrônica da Faculdade de Tecnologia e Ciências de Feira de Santana. Ano I, n. 1, dez. 2002.

PROPP, V. I. Morfologia do conto maravilhoso. Rio de Janeiro: Forense universitária, 1984.

RAMOS, J. E. F. A Ciência e o Insólito: o conto de literatura fantástica no Ensino de Física. 2012. Tese (Dissertação em Ensino de Ciências (Modalidades Física)) - Universidade de São Paulo,São Paulo. 2012.

REIMÃO, S. Literatura policial brasileira. Rio de Janeiro: Jorge Zahar Ed., 2005. O que é romance policial?. Brasiliense, 1983.

RESENDE, V. M. Literatura infantil e juvenil: relatos de experiência na escola. Minas Gerais: Comunicação, 1983. Literatura infantil e juvenil: vivências de leitura e expressão criadora. São Paulo: Saraiva, 2000.

SANTOS, E. I. ; PIASSI, L. P. C. ; VIEIRA, R. M. B. O Demolidor: filmes de ficção científica tratando de questões socioambientais na sala de aula. Educação Ambiental em Ação, v. 30, p. 5-0, 2009.

SANTOS, F. R. ; PIASSI, L. P. C. Filmes de ficção científica como recurso didático no ensino de conteúdos de educação ambiental. 2009.

SILVA, V. M. T. Literatura infantil brasileira: um guia para professores e promotores da leitura. Goiânia: Cânone, 2009.

SOUZA, L. S. Introdução às teorias semióticas. Petrópolis: Vozes, 2006

TARDY, M. O professor e as imagens. Trad: BARROS, Frederico P. São Paulo: Cultrix, 1976.

VAN DIJK, T. Cognição, discurso e interação. São Paulo: Contexto, 2002.

WAAL, F. de. Eu, primata: porque somos como somos. 1 ed. São Paulo: Companhia das Letras, 2007. 331p.

ZABALA, A. A prática educativa: como ensinar. Porto Alegre: Artmed, 1998. Como trabalhar os conteúdos procedimentais em sala de aula. São Paulo: Artmed, 1999. 
ZANETIC, J. Literatura e cultura científica. In: ALMEIDA, M. J. P. M; SILVA, H. C. (Org.). Linguagens, leituras e ensino da ciência. , p. 121-130. Campinas, SP: Mercado de Letras; ALB, 1998.

Física e cultura. Ciência e cultura. v. 57, n.3, p. 21-24. Jul-set. 2005. 


\section{ANEXO A - FiCHA de LEITURA do LiVRO O CASO dA BORBOLETA ATÍrA}

\section{Suplemento de Jrabalho \\ EO \\ o Caso da Borboleta Atíria, de Lúcia Machado de Almeidia.}

Nome grau____ série _____

Estabelecimento

I. PERsonagens

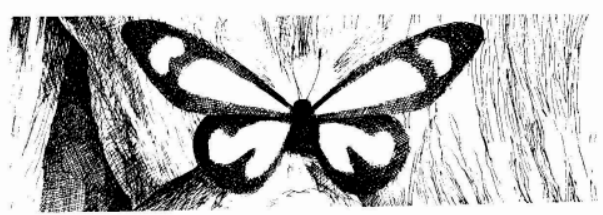

1. Você viu cada susto que passei? Agora, vivo feliz com meu Principe. E graças ao Papilio. Ele mostrou que è mesmo um grande detetive. Quem vai bancar o detetive agor é você. Complete este quadro seguindo as minhas dicas:

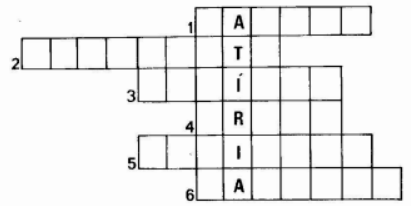

1. A borboleta perversa que se fingia amiga de Grilo e de Papilio, e que me aprisionou.

Grilo e de Papilio, e que me aprisionou.

2.

4. O detetive que descob

O nome de minha mãe.

A segunda noiva do Principe, que foi assassinada A segunda noiva do Principe,
com um ramo de mancenilha.

2. Aqui você tem uma colmeia como aquela que viu no livro. Preencha as celas da colmeia com as indicaçōes dos itens

dos ponteiros do relógio.

Para sua orientação, eu já deixo feito o primeiro

1. A forma de tratamento que se usa em relação ao Principe Grilo.

2. A noiva do Esqueleto-Vivo.

3. Meu nome

4. A soberana da colmeia.

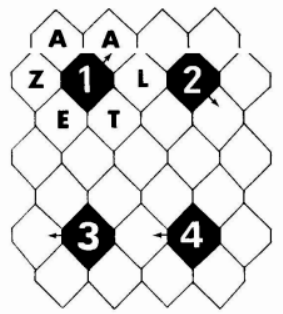

II. NARRATIVA

1. Muita coisa aconteceu nessa estória. Vamos ver se você se lembra de alguns fatos importantes? Então. preencha as lacunas:

a O lugar em que eu morava chamava-se Reino

b. Quando nasci não havia ninguém que olhasse por mim, por isso__ resolveu me adotar.

c. Eu levava uma desvantagem perante as outras borboletas, porque eu tinh

d. Quando a estória começa, já haviam matado a noiva do Príncipe. Mais tarde, outro assassinato acontece:

ramo de mancenilha.

e. A Rainha das abelhas chama A larvicidio na colmeia. Ai ele descobre que quem matava as larvas para roubar o mel

eram mave

f. No dia em que se apresentou cantando no concerto, Papilio afinal teve a comprovação de suas dúvidas. Ao ver__ de cabeça para baixo, constatou que era ela a assassina, por causa de

g. Caligo era aliada ao _ seu noivo. Eles queriam e me prenderam para atrair a atenção do

h. Assim que notaram minha falta, convocou todos os insetos para lutar contra.

i. Eu fui jogada num cubículo onde estava uma peluda. Tive sorte e não morri porque o bicho estava na época da j. Foram muitos os feridos, mas nós vencemos a batalha $\mathrm{O}$ meu casamento com ___ foi uma festa tão bonita que ninguém jamais esqueceu.

III. NARRADOR

1. O narrador, durante o relato da estória, dá algumas dicas do mistério. Coloque as dicas em ordem, de acordo com o seu aparecimento na estória:

(1) Papílio vê Caligo de cabeça para baixo.

( ) Papilio ouve uma conversa entre uma possivel coruja e um inseto.

( ) Dentro do túnel do parque de diversōes, assusto-me porque vejo dois olhos misteriosos.

IV. VOCE APRENDEU

1. Aposto que você aprendeu uma porção de coisas sobre os insetos. Eu vou embaralhar as letras e você decifra as palavras, tá?

a. As borboletas e outros insetos sofrem MTEMFOORESA.

b. As borboletas sugam o C TNARE das flores.

A abetha rainha põe cerca de três mil ovos por dia em cada VLLAOÉO.

d. Numa colmeia existem os NGEAZS Õ, as BORIEARS e a HAAIN R.

e. A futura rainha de uma colmeia recebe uma alimentação especial de NPOLE misturado com ECTRAN concentrado, para que se desenvolva mais que as outras abelhas.

f. As abelhas quando produzem o mel segregam uma substância ácida que impede sua RFEMNEÃ OÇTA.

Somente os machos das PAASKCIK cantam.

\section{v. AMBIENTE}

1. Neste novo exercício, se você usar cores diferentes, formara um desenho muito bonito.

Passe um lápis de cor sobre os nomes errados:

1. Procure na faixa 1 o lugar onde se passa a história.

2. Procure na faixa 2 a alameda onde eu e Mamăe Jitirana morávamos.

3. Procure na faixa 3 quando foram cometidos os dois crimes.

4. Procure na faixa 4 o nome da gruta onde foi batalha final.

5. Procure na faixa 5 a lingua mais falada nesse reino.

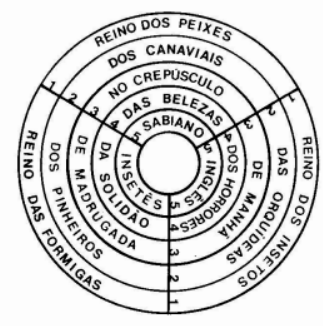

VI. MENSAGEM

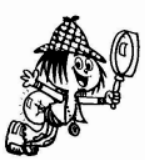

Como é, você conseguiu desvendar o mistério antes do final do livro? Romance policial joia é assim mesmo: parece ate um jogo de quebra-cabeça. Por isso, eu me liguei nct E vece ao fim. 


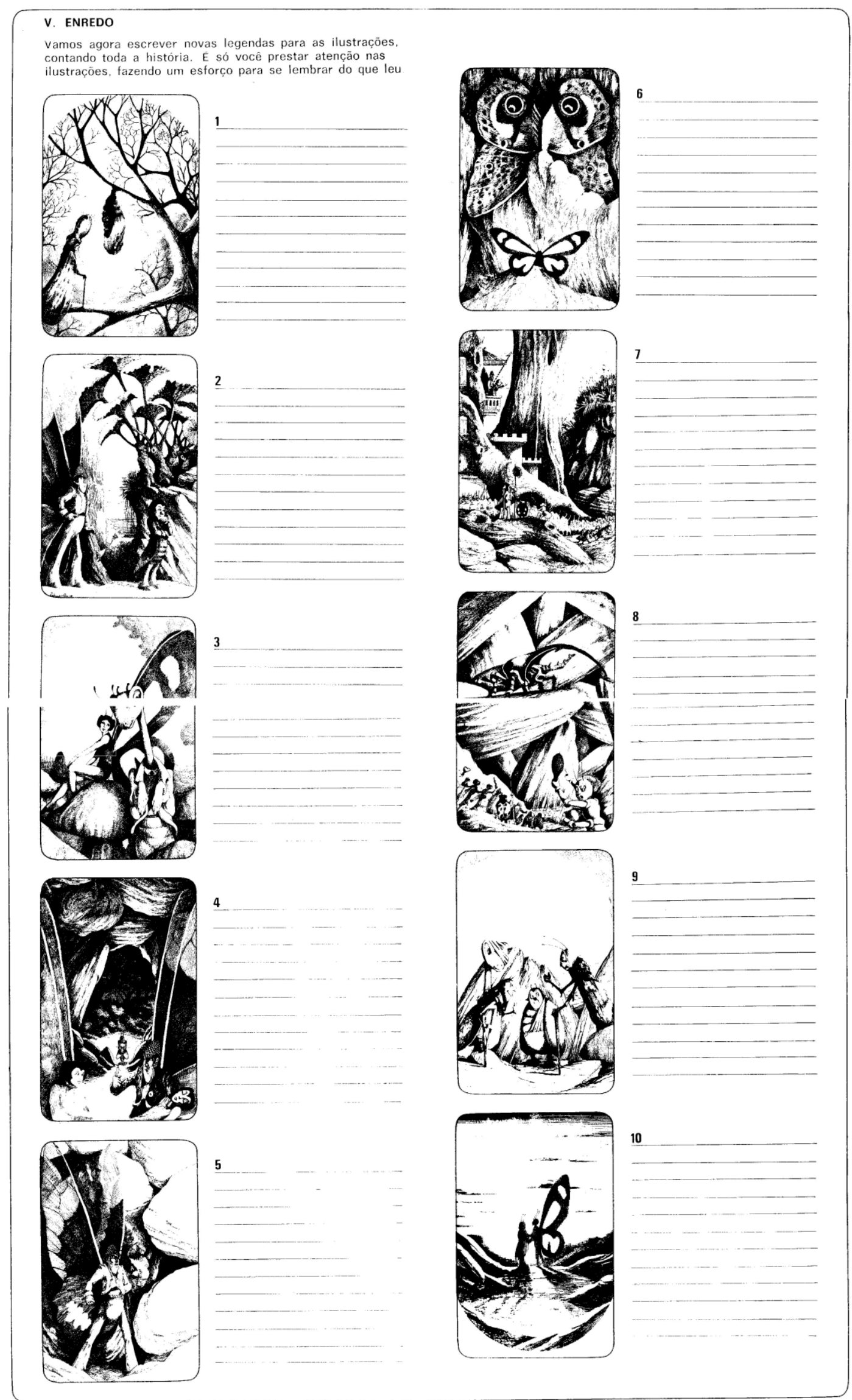

Não pode ser vendido separadamente. Reproduçāo Proibida. @ Editora Ática S. A 
ANEXO B - OBRAS QUE FAZEM PARTE DA SÉRIE VAGA-LUME

\begin{tabular}{|c|c|}
\hline Título & Autor \\
\hline A Aldeia Sagrada & Francisco Marins \\
\hline A Árvore que Dava Dinheiro & Domingos Pellegrini \\
\hline A Charada do Sol e da Chuva & Luiz Galdino \\
\hline A Chave do Corsário & Eliana Martins \\
\hline A Grande Fuga & Luiz Galdino \\
\hline A Grande Virada & Raul Drewnick \\
\hline A Guerra do Lanche & Lourenço Cazarré \\
\hline A Hora da Decisão & Raul Drewnick \\
\hline A Ilha Perdida & Maria José Dupré \\
\hline A Ladeira da Saudade & Ganymédes José \\
\hline A Magia da Árvore Luminosa & Rosana Bond \\
\hline A Maldição do Tesouro do Faraó & Sérsi Bardari \\
\hline A Montanha das Duas Cabeças & Francisco Marins \\
\hline A Noite dos Quatro Furacões & Raul Drewnick \\
\hline A Primeira Reportagem & Sylvio Pereira \\
\hline A Serra dos Dois Meninos & Aristides Fraga Lima \\
\hline A Turma da Rua Quinze & Marçal Aquino \\
\hline A Vida Secreta de Jonas & Luiz Galdino \\
\hline A Vingança da Cobra & Marcos Bagno \\
\hline Açúcar Amargo & Luiz Puntel \\
\hline Agitação à Beira-Mar & Leusa Araujo \\
\hline Ameaça nas Trilhas do Tarô & Sérsi Bardari \\
\hline Aventura no Império do Sol & Silvia Cintra Franco \\
\hline Aventuras de Xisto & Lúcia Machado de Almeida \\
\hline Bem-Vindos ao Rio & Marcos Rey \\
\hline Cabra das Rocas & Homero Homem \\
\hline Cem Noites Tapuias & Ofélia e Narbal Fontes \\
\hline Confusões \& Calafrios & Silvia Cintra Franco \\
\hline Coração de Onça & Ofélia e Narbal Fontes \\
\hline Correndo contra o Destino & Raul Drewnick \\
\hline Corrida Infernal & Marcos Rey \\
\hline Crescer é uma Aventura & Rosana Bond \\
\hline Deu a Louca no Tempo & Marcelo Duarte \\
\hline Deus me Livre! & Luiz Puntel \\
\hline Dinheiro do Céu & Marcos Rey \\
\hline Doze Horas de Terror & Marcos Rey \\
\hline Em Busca do Diamante & Francisco Marins \\
\hline Enigma na Televisão & Marcos Rey \\
\hline Éramos Seis & Maria José Dupré \\
\hline Garra de Campeão & Marcos Rey \\
\hline Gincana da Morte & Marcos Rey \\
\hline Jogo Sujo & Marcelo Duarte \\
\hline
\end{tabular}




\begin{tabular}{|c|c|}
\hline 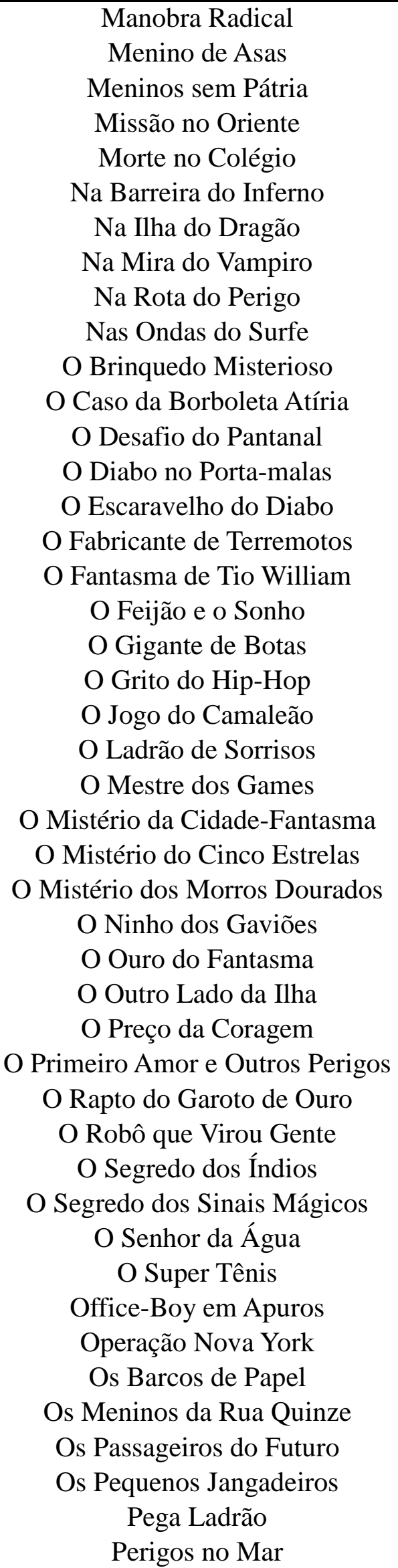 & 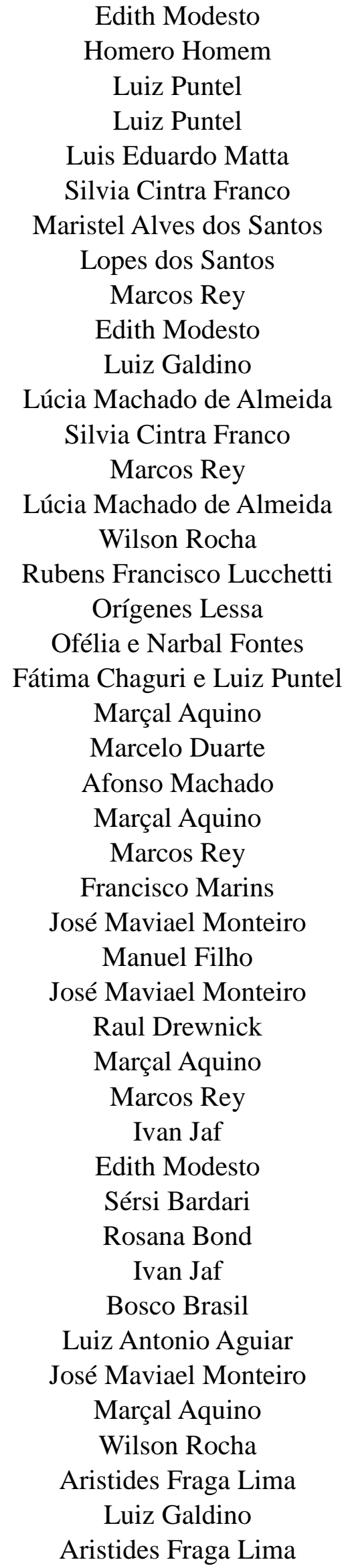 \\
\hline
\end{tabular}




\begin{tabular}{|c|c|}
\hline Quem Manda Já Morreu & Marcos Rey \\
Quem Está Perseguindo Zero-Zero-Au? & Thomas Brezina \\
Salvando a pele & Mário Teixeira \\
Segura, Peão! & Luiz Galdino \\
S.O.S. Ararinha-Azul & Edith Modesto \\
Sozinha no Mundo & Marcos Rey \\
Spharion & Lúcia Machado de Almeida \\
Tem Lagartixa no Computador & Marcelo Duarte \\
Terror na Festa & Janaína Amado \\
Tonico & José Rezende Filho \\
Tonico e Carniça & Luiz Puntel \\
Tráfico de Anjos & Marcos Rey \\
Um Cadáver Ouve Rádio & Wilson Rocha \\
Um Gnomo na Minha Horta & Raul Drewnick \\
Um Inimigo em Cada Esquina & Luiz Puntel \\
Um Leão em Família & Marcos Rey \\
Um Rosto no Computador & Raul Drewnick \\
Vencer ou Vencer & Lô Galasso \\
Viagem pelo Ombro da Minha Jaqueta & Lúcia Machado de Almeida \\
Xisto e o Pássaro Cósmico & Lúcia Machado de Almeida \\
Xisto no Espaço & Jair Vitória \\
\hline Zezinho, o Dono da Porquinha Preta & \\
\hline
\end{tabular}




\section{Anexo C - Capas das edições de O Caso da borboleta Atíria}
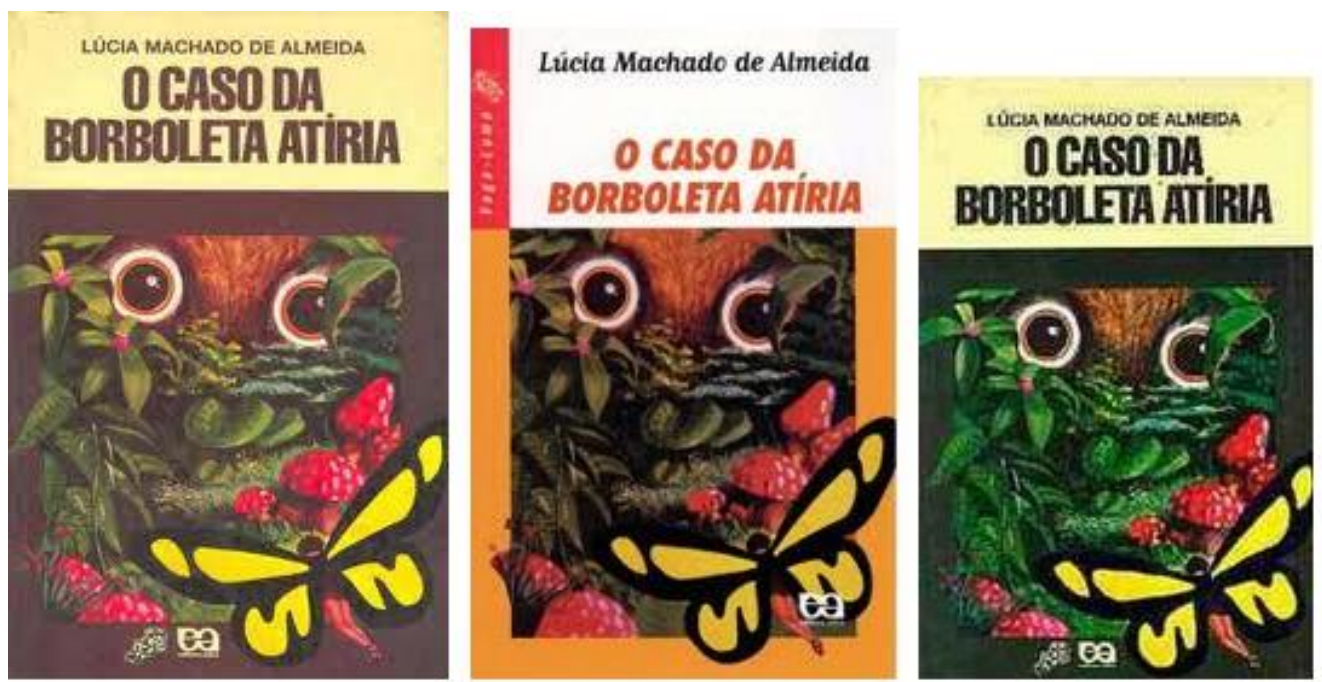

Figura 29 Capas de edições diversas da obra $\mathbf{O}$ caso da borboleta Atíria

\section{ANEXo D - CONTRACAPA DO LIVRO O CASO DA BORbOLETA ATÍRIA COM A CAPA} DE OUTROS EXEMPLARES

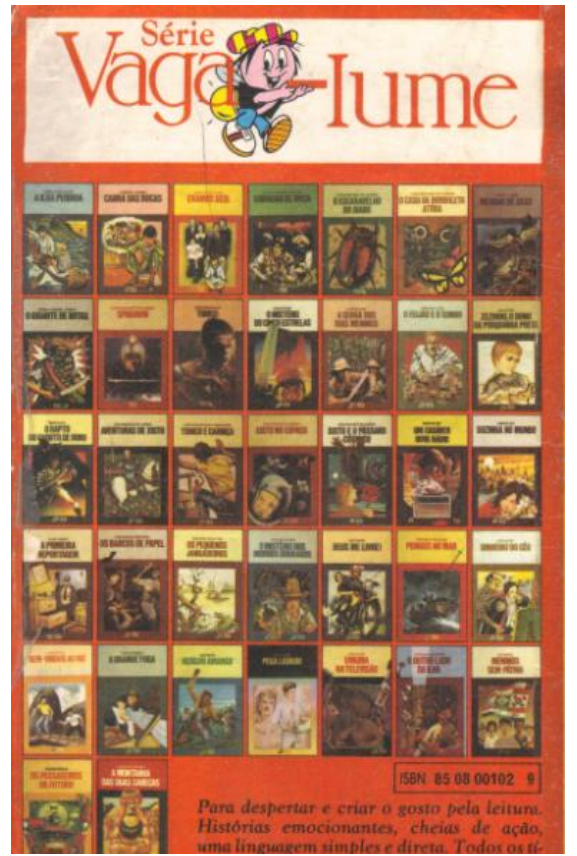

Figura 30 Contracapa da obra $O$ caso da borboleta Atíria 